\title{
Synthesis of Cyclopropanes via 1,3-Migration of Acyloxy Groups Triggered by Formation of a-Imino Rhodium Carbenes
}

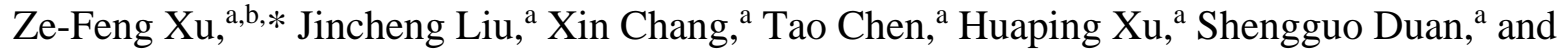
Chuan-Ying $\mathrm{Li}^{\mathrm{a}}$ **

aDepartment of Chemistry, Zhejiang Sci-Tech University, Xiasha West Higher Education District, Hangzhou, 310018, China.

${ }^{b}$ Key Laboratory of Organofluorine Chemistry, Shanghai Institute of Organic Chemistry, Chinese Academy of Sciences, 345 Lingling Road, Shanghai 200032, China 


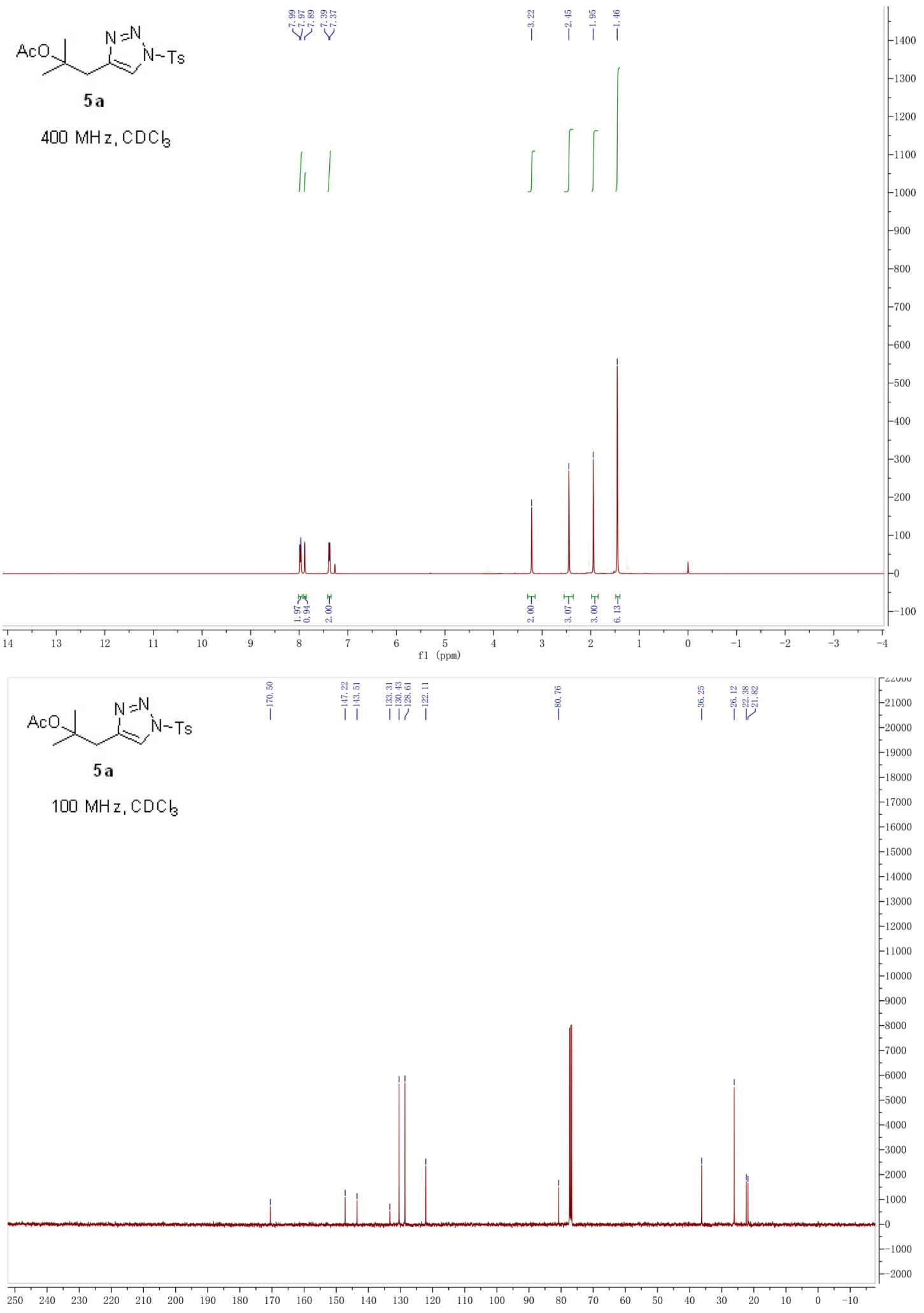



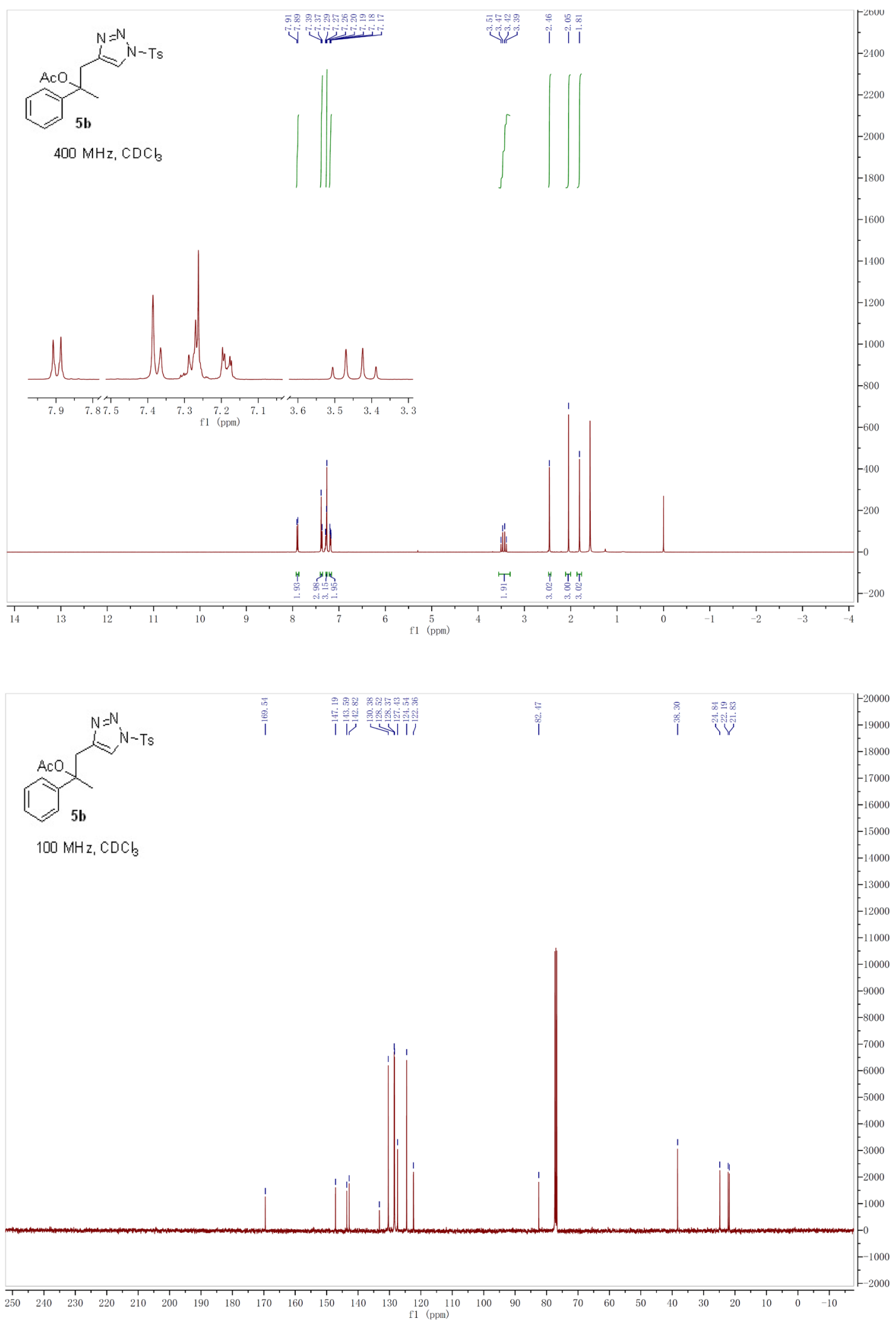

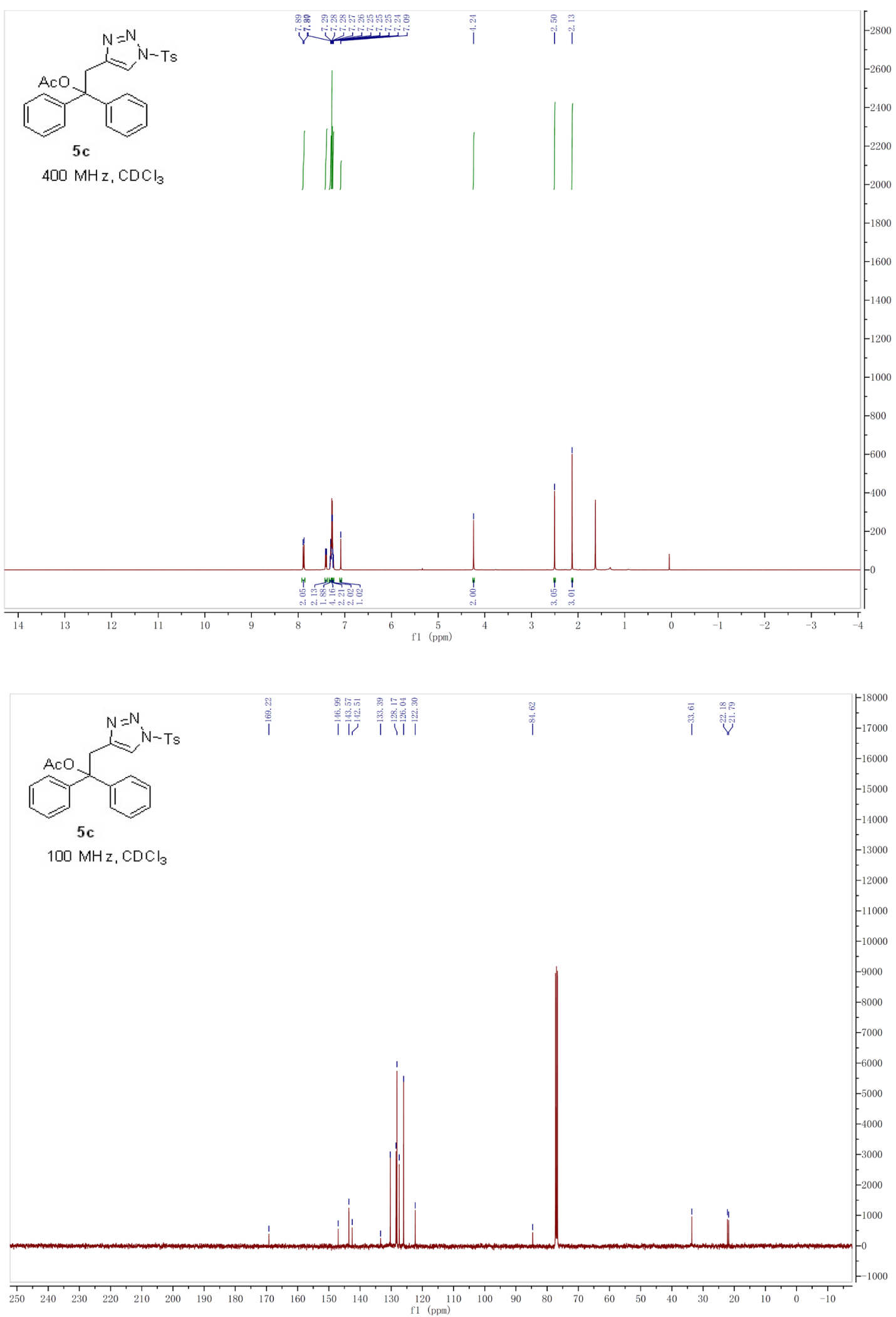

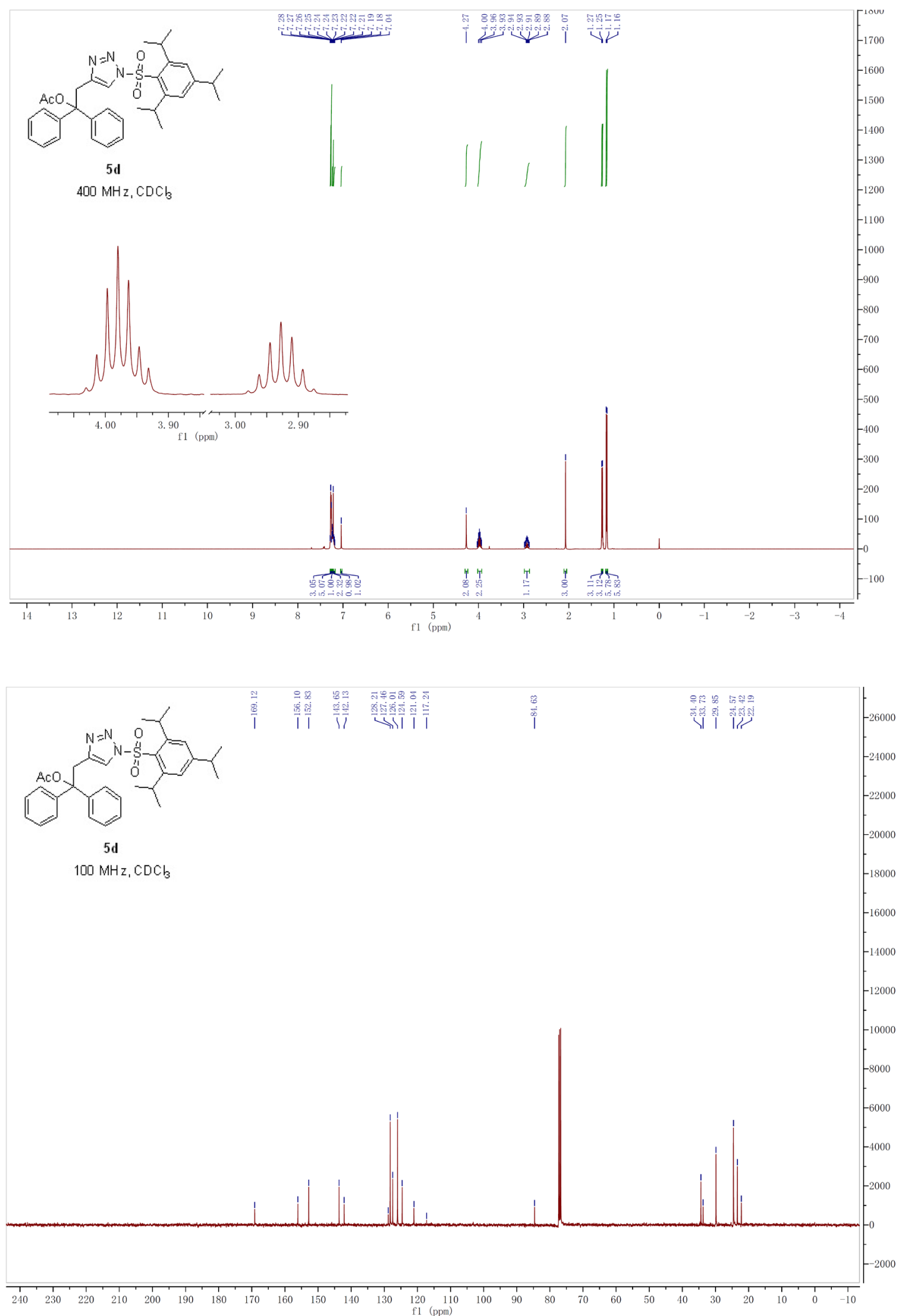

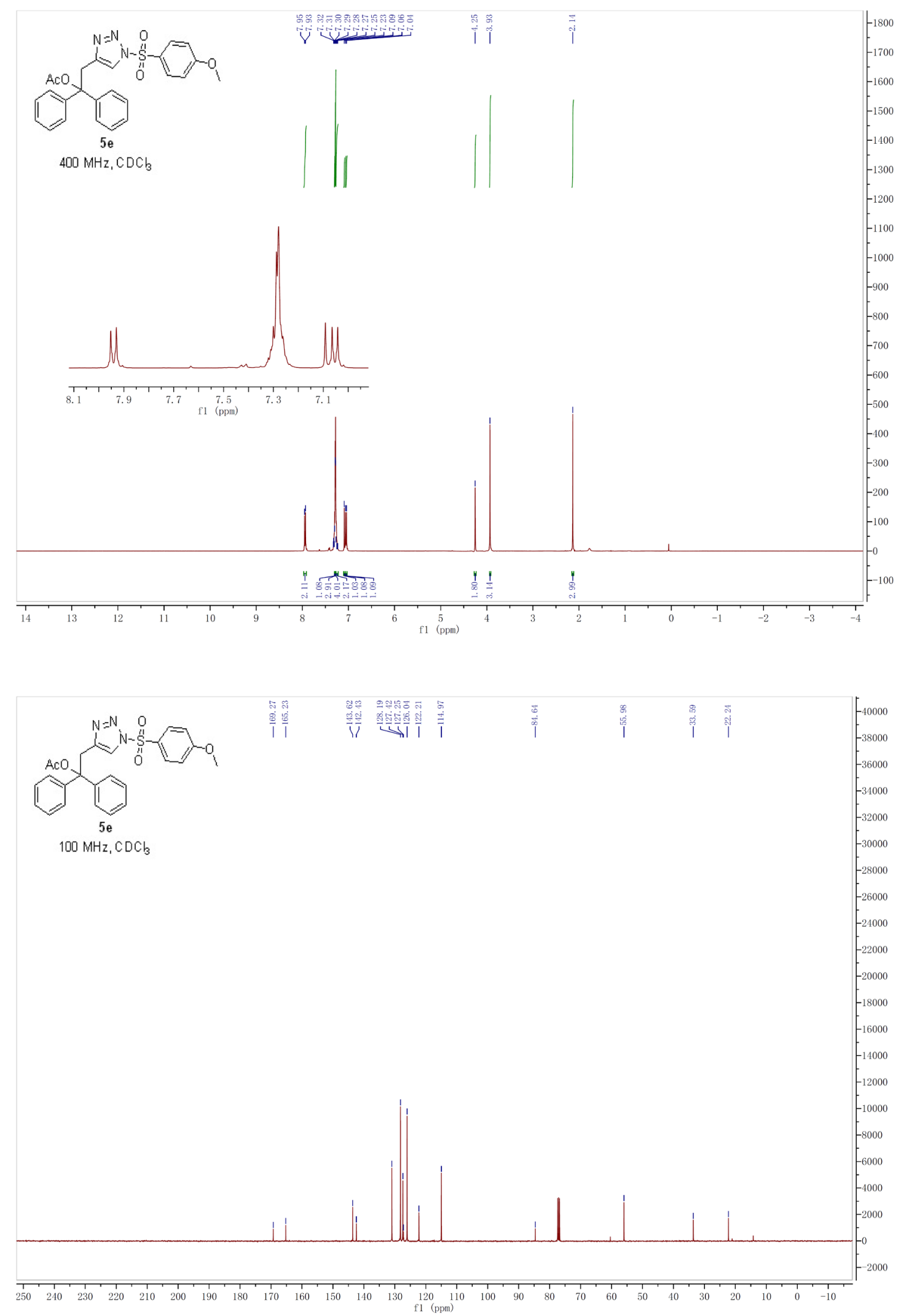

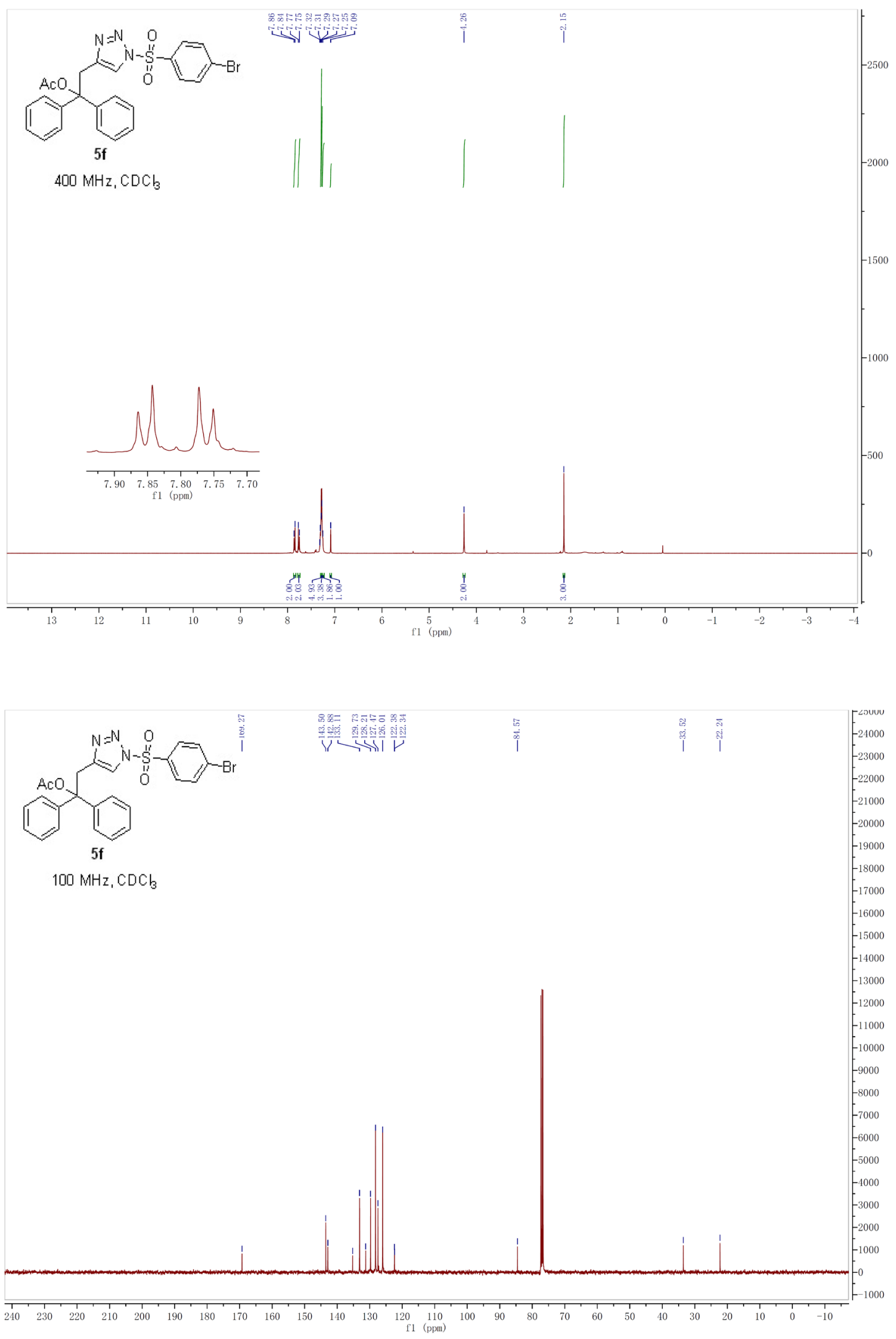

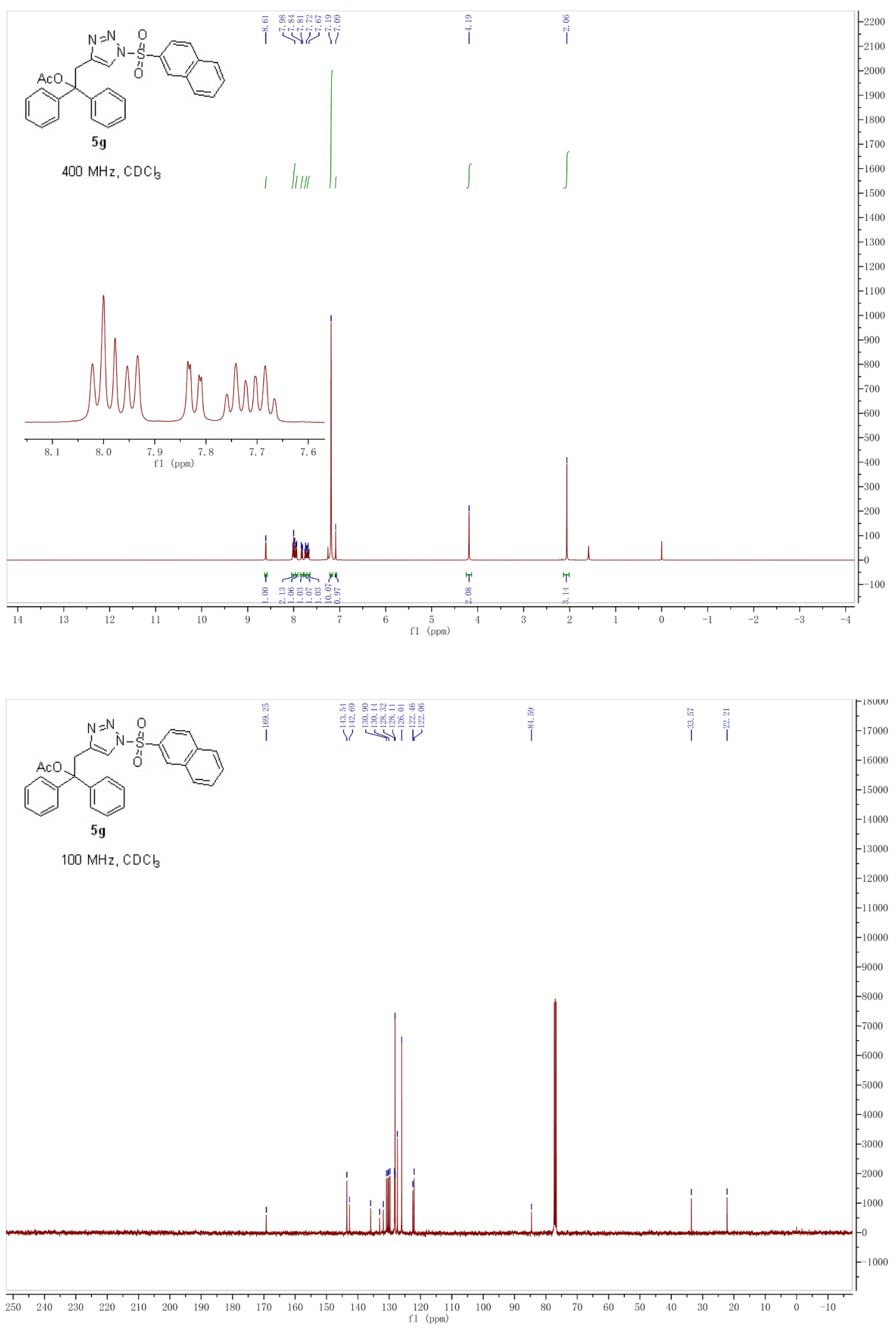

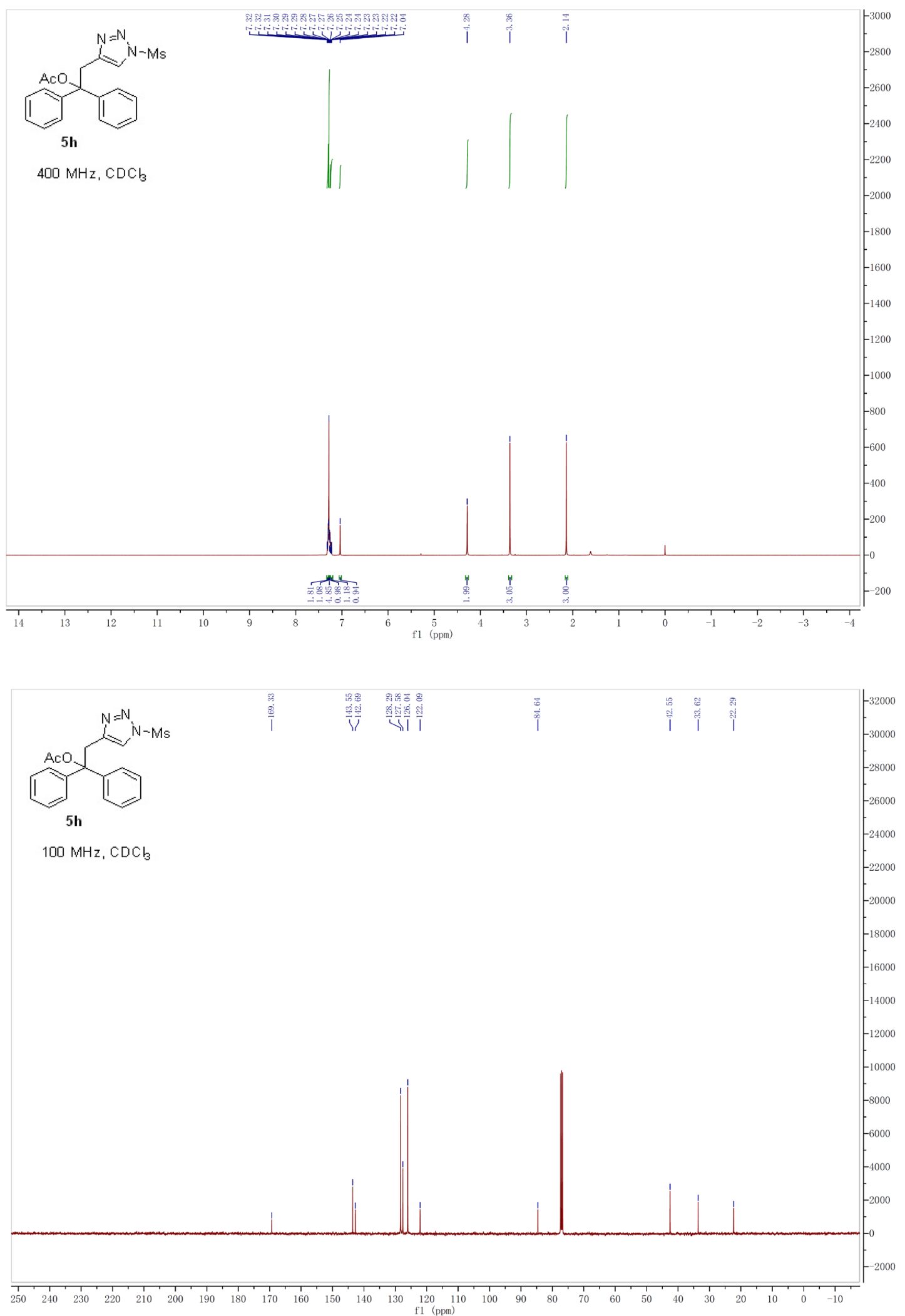

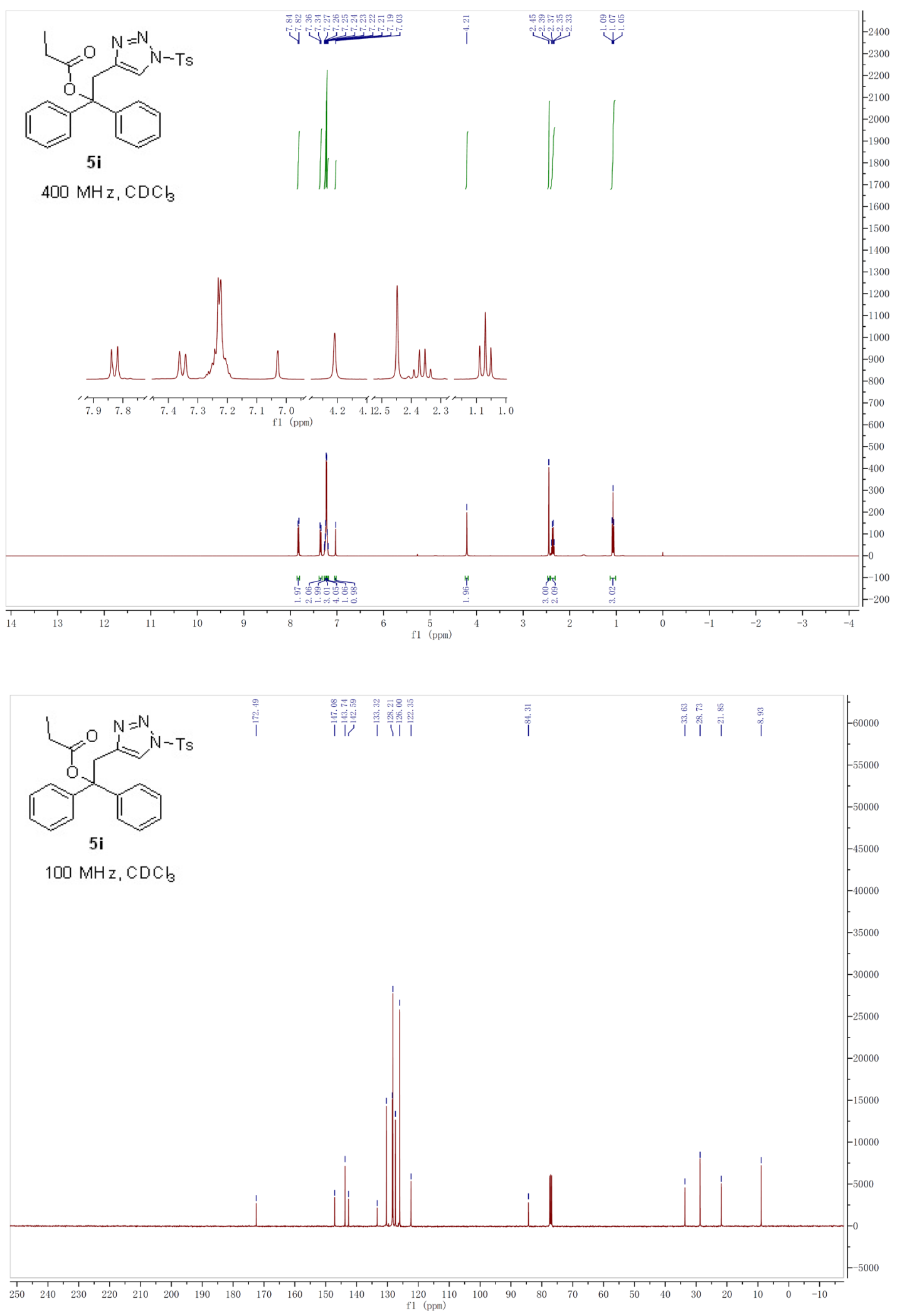

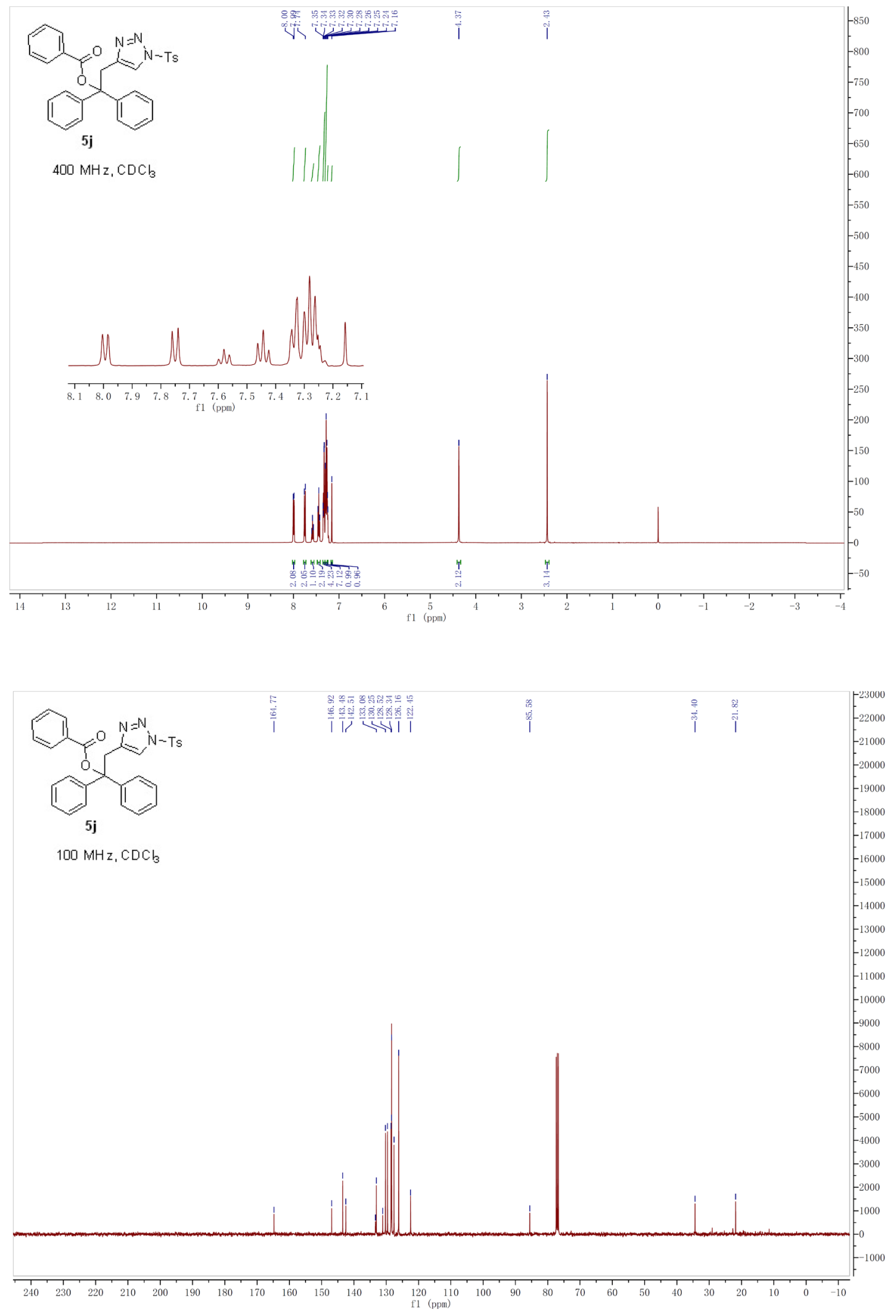

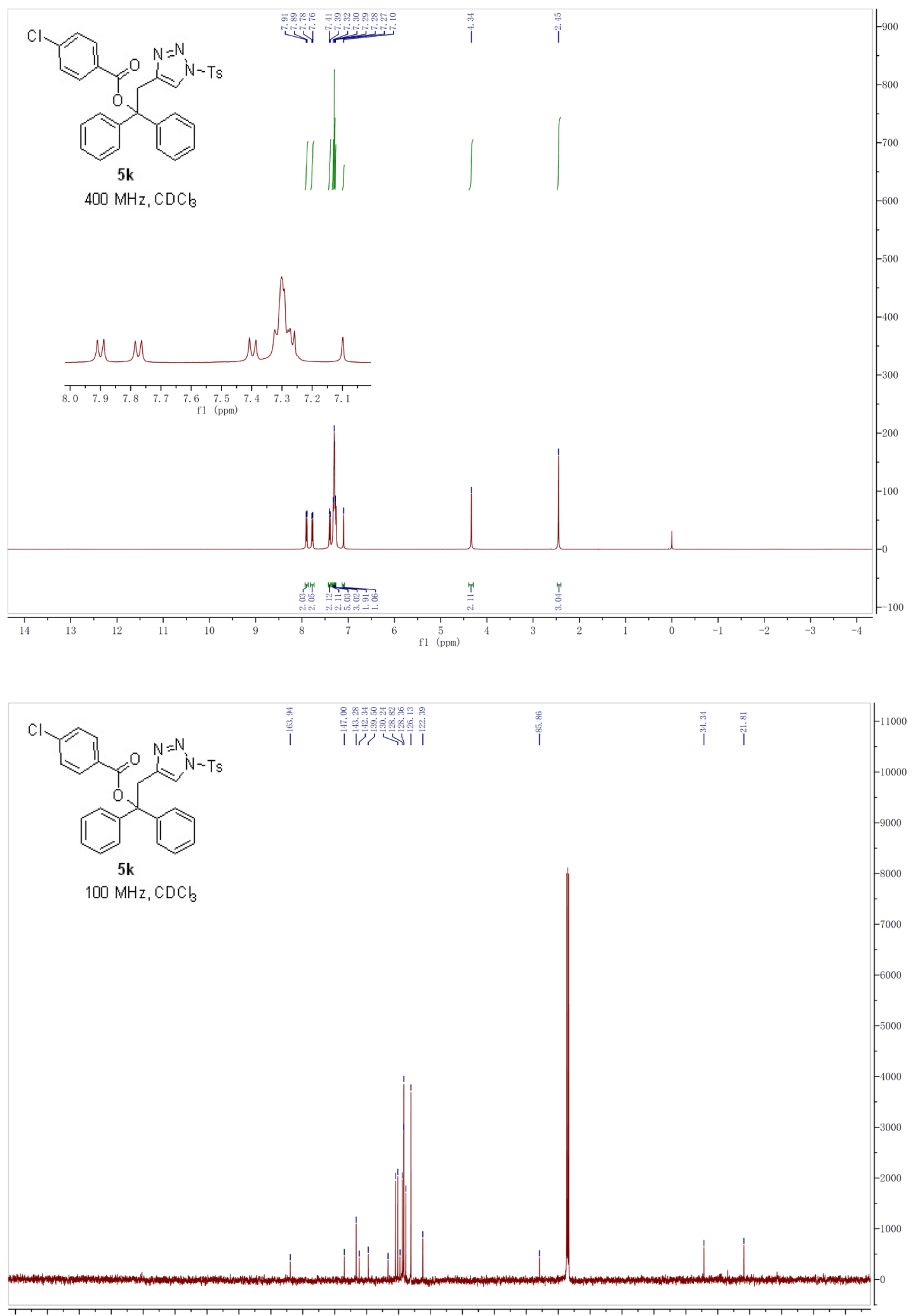

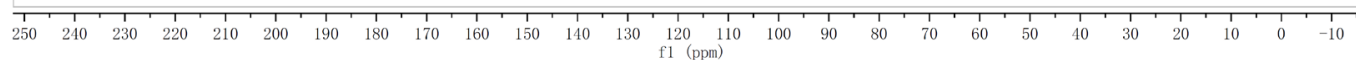



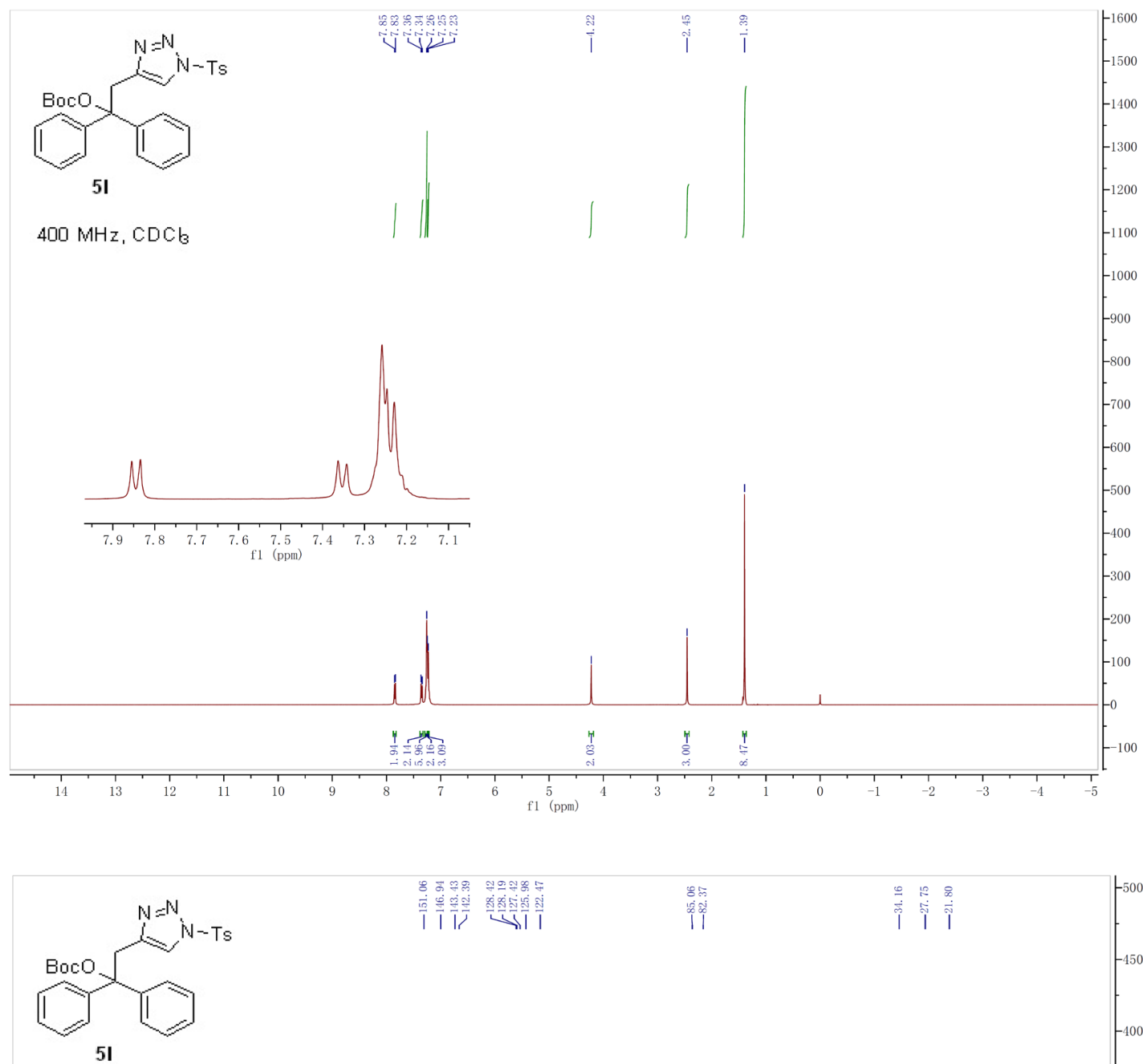

$100 \mathrm{MHz}, \mathrm{CDCl}$

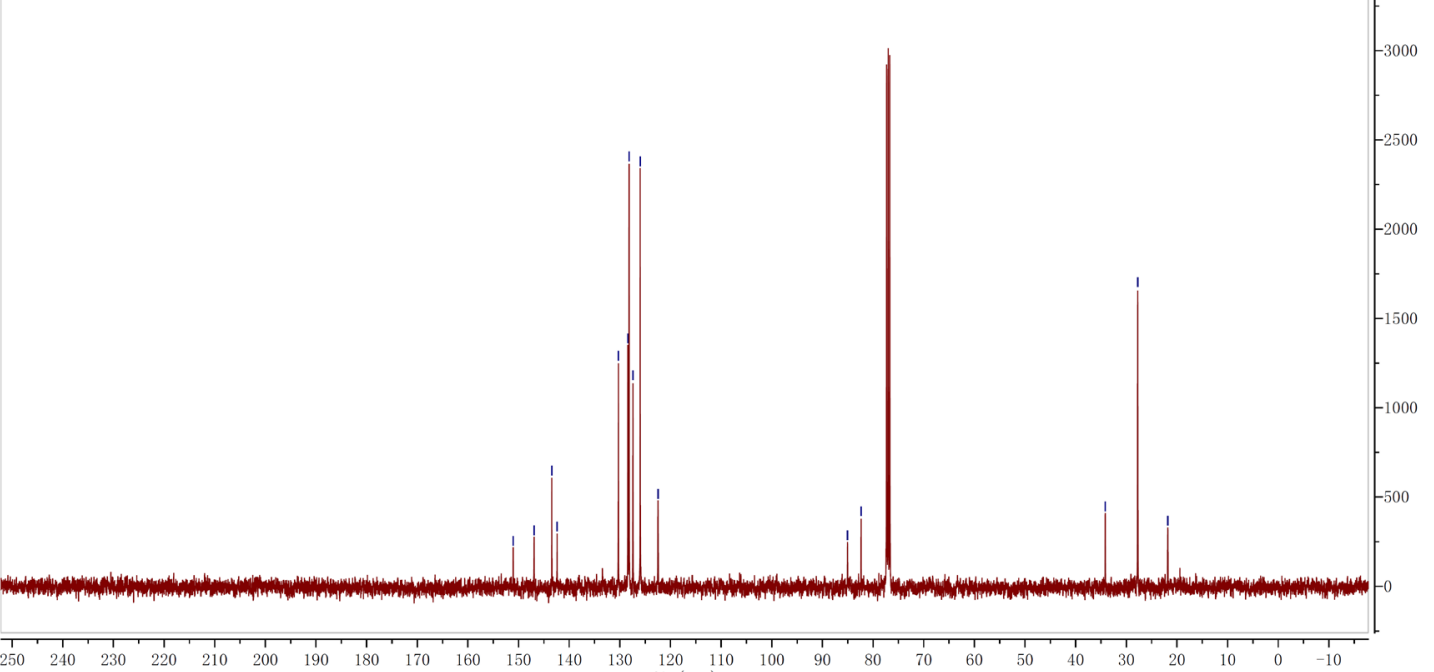

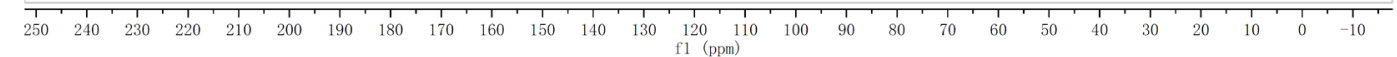



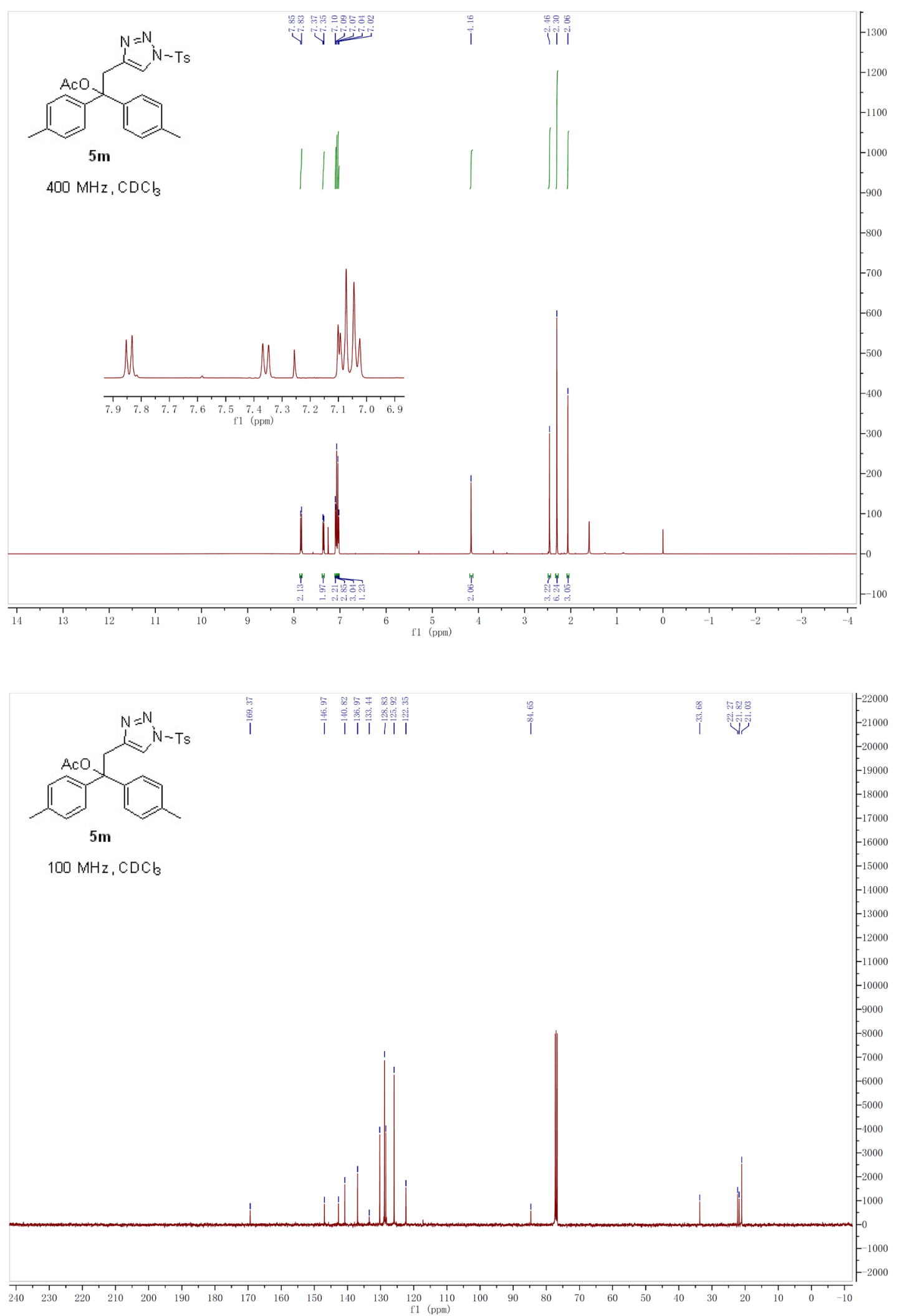

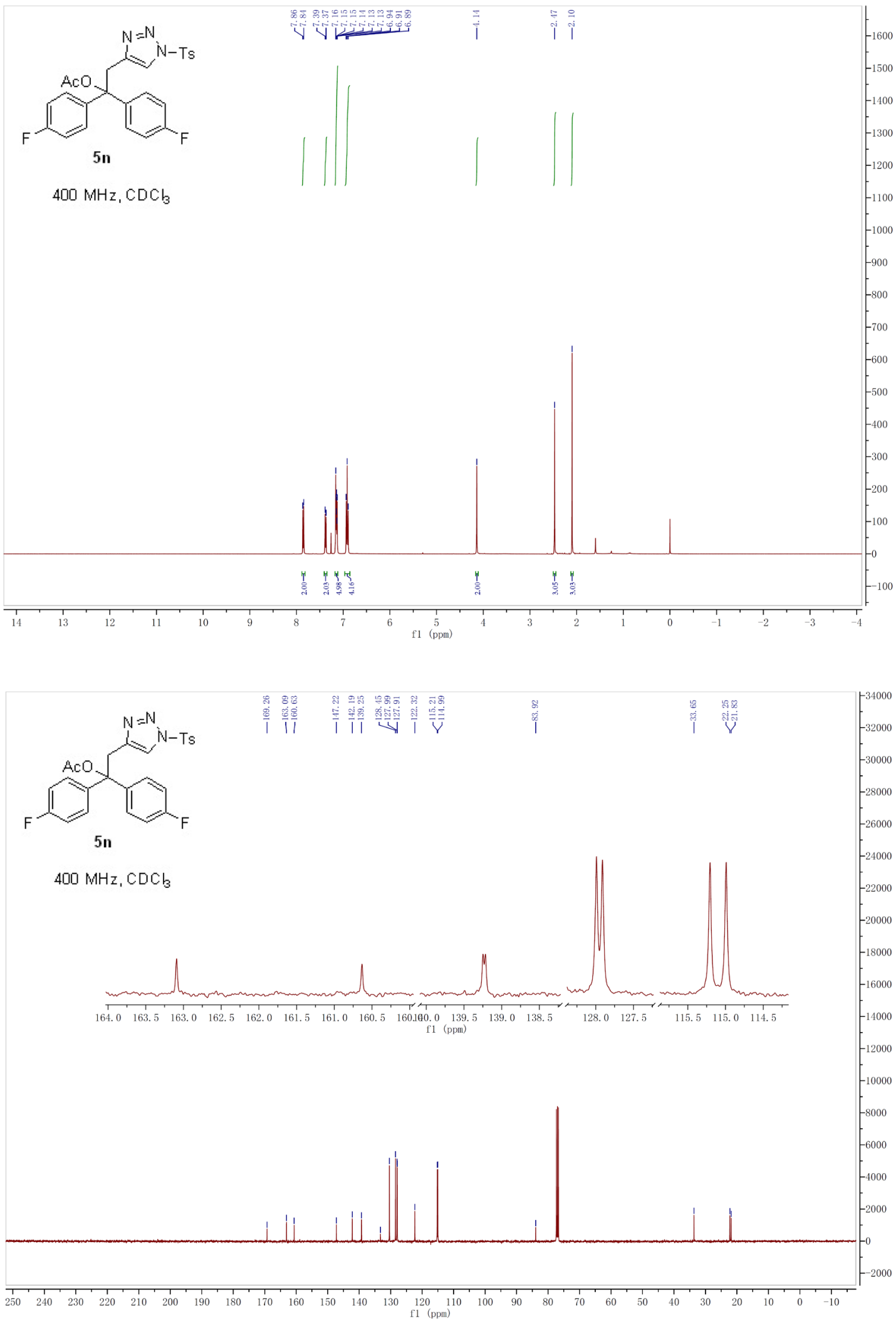

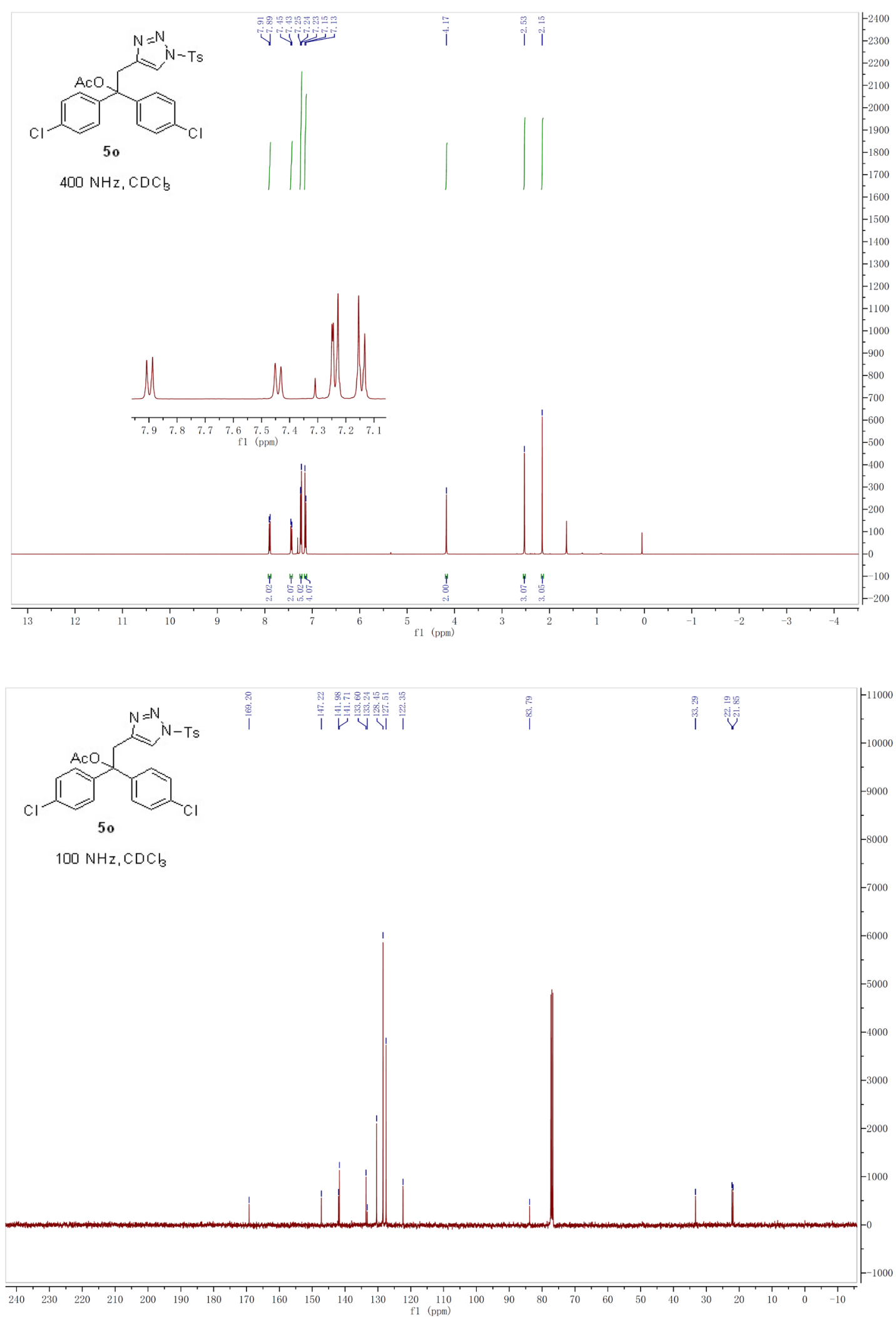

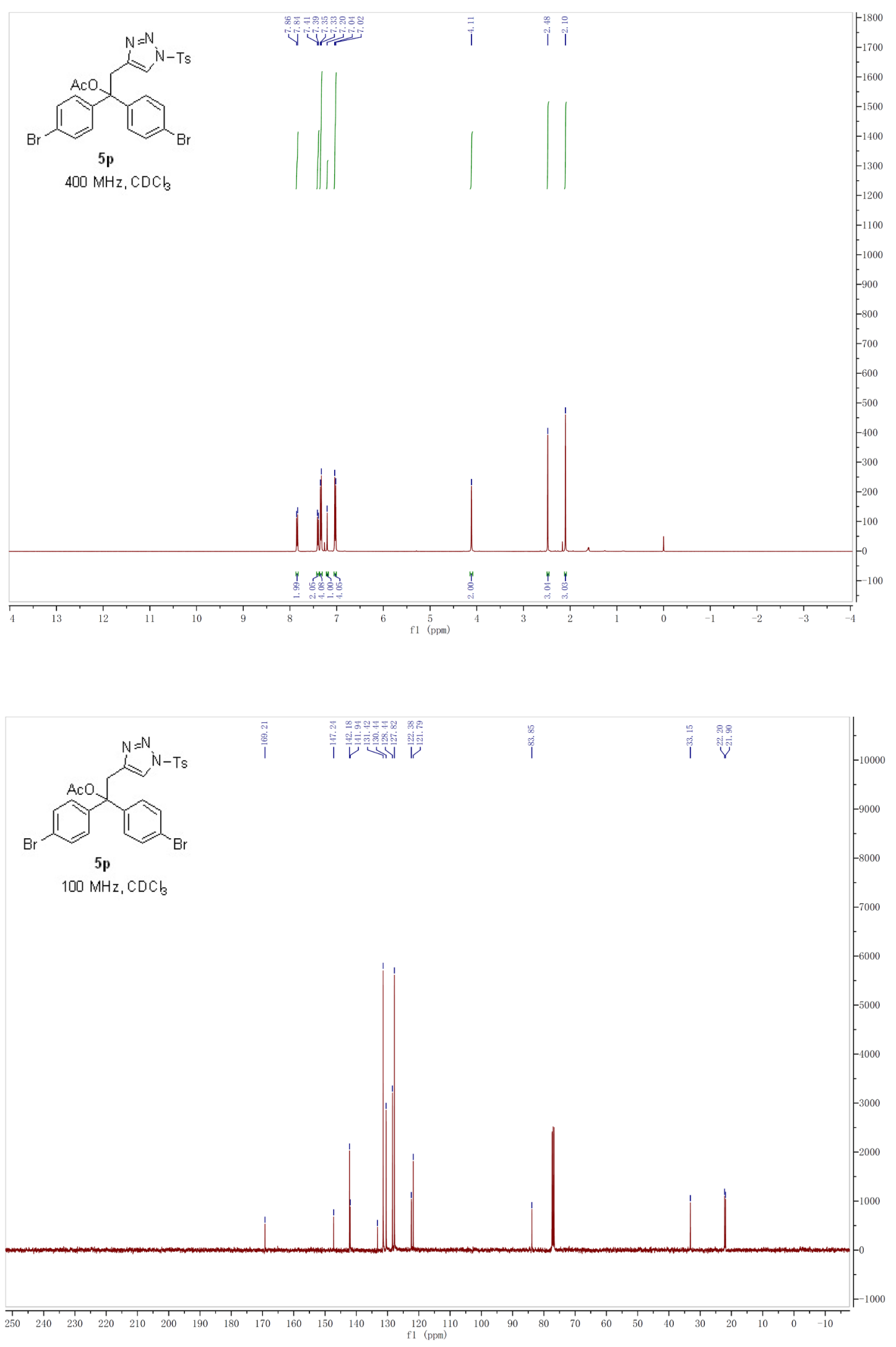

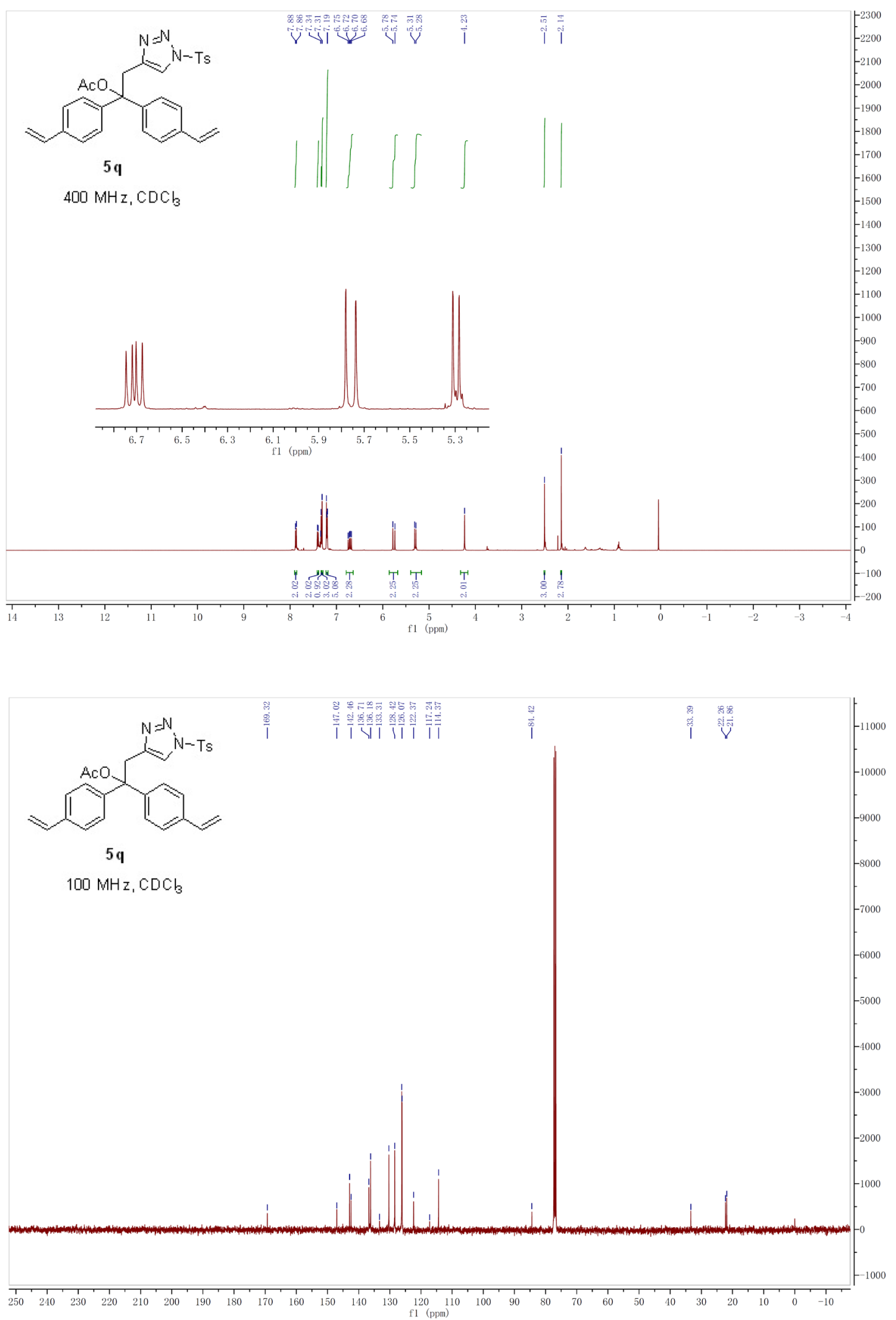

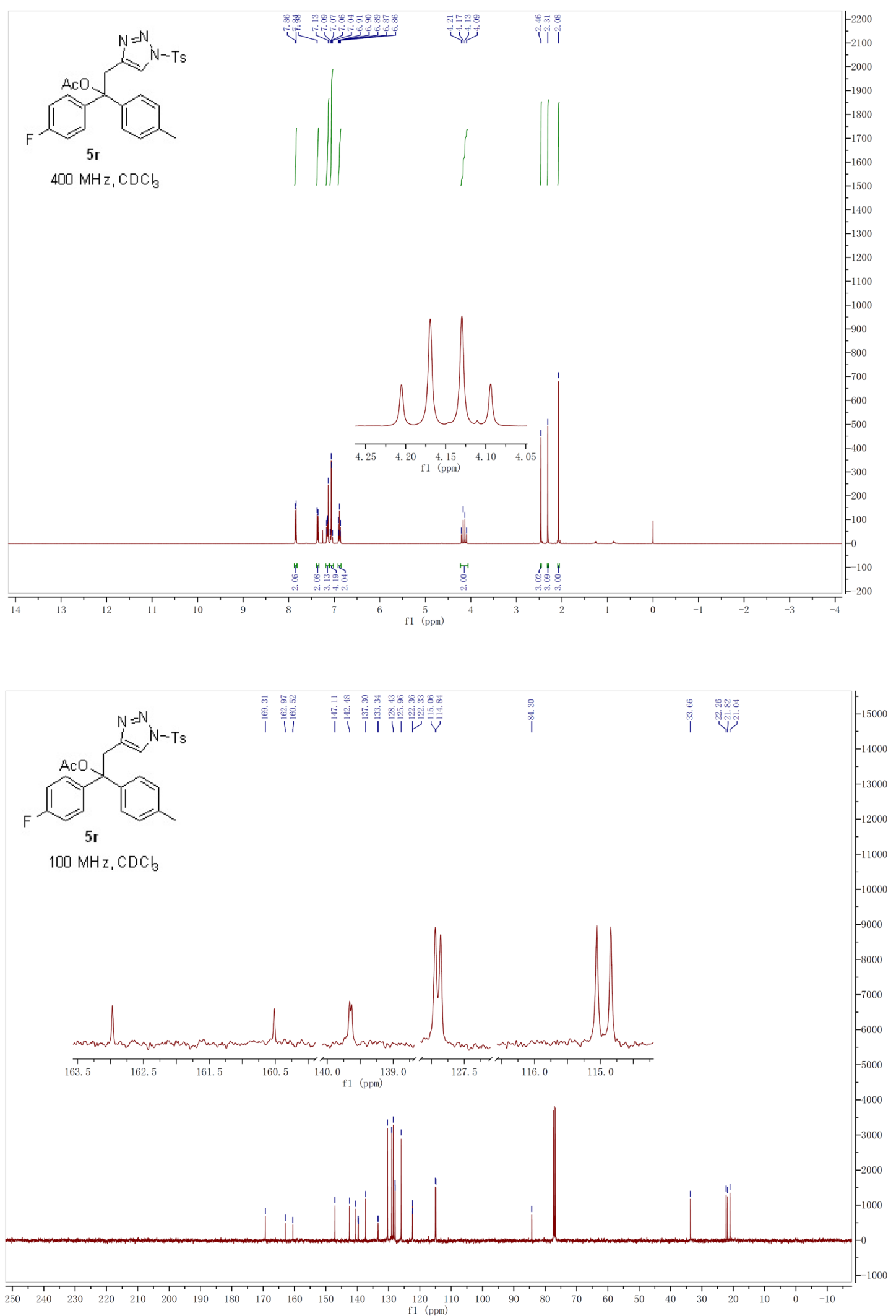

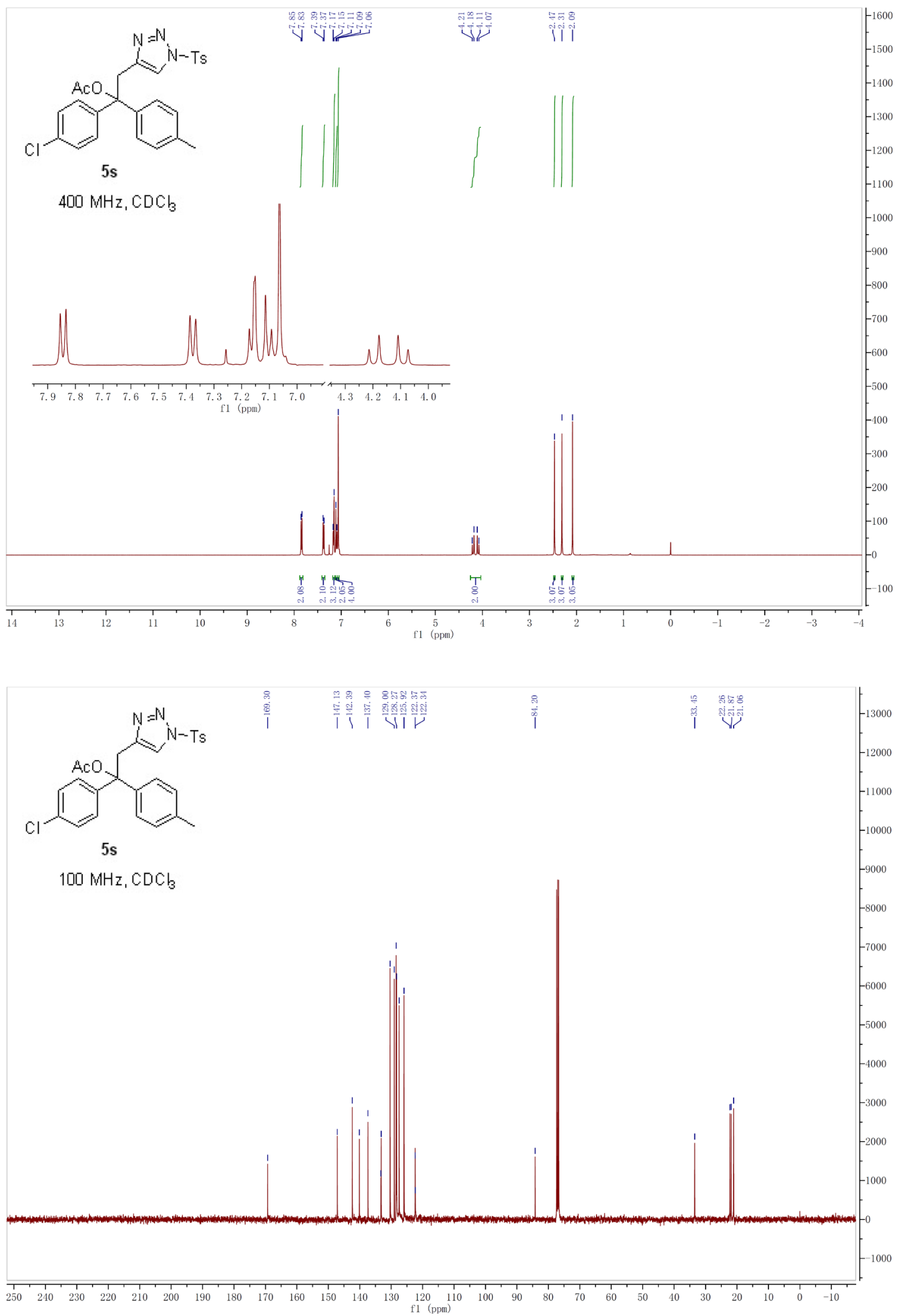

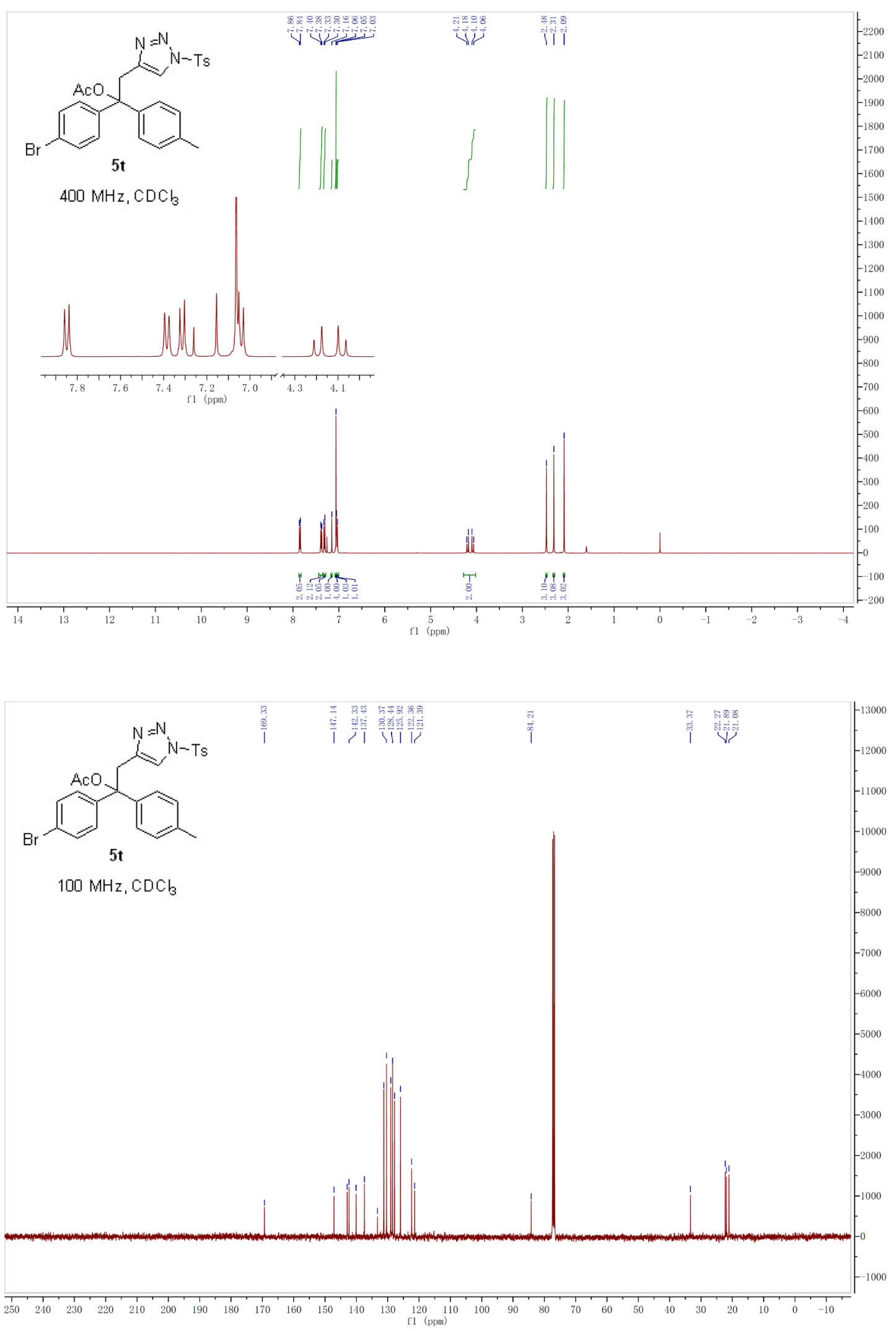

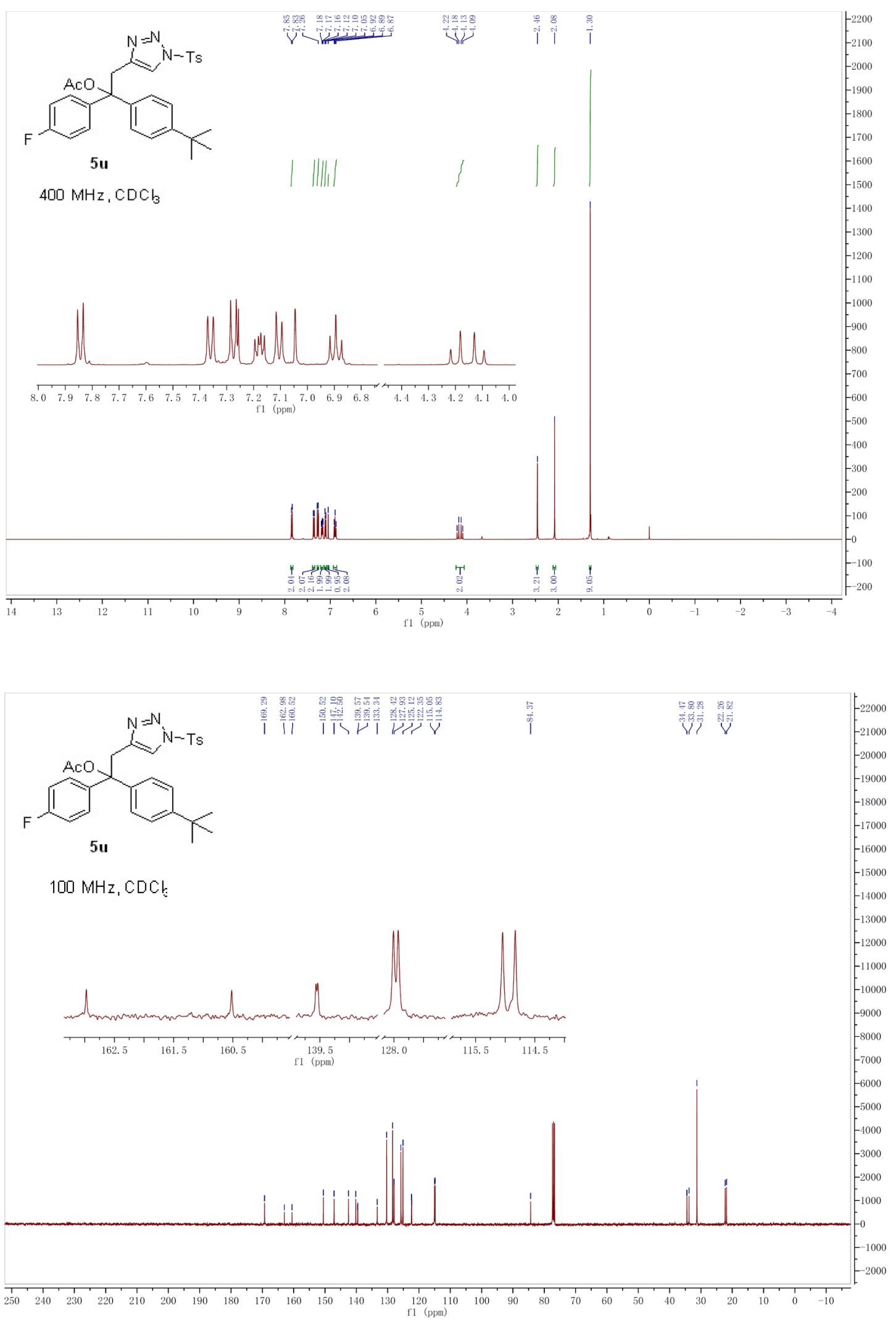

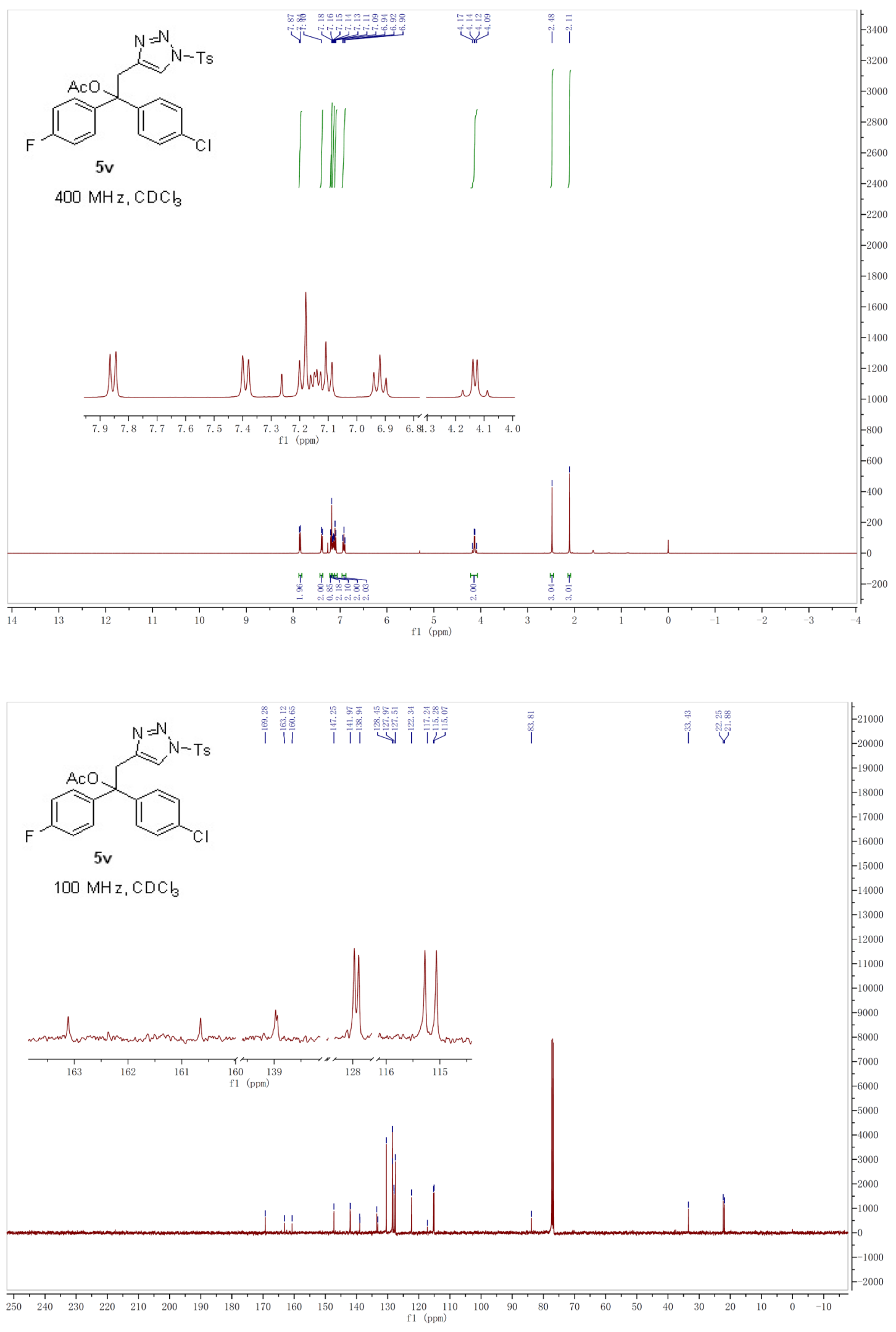

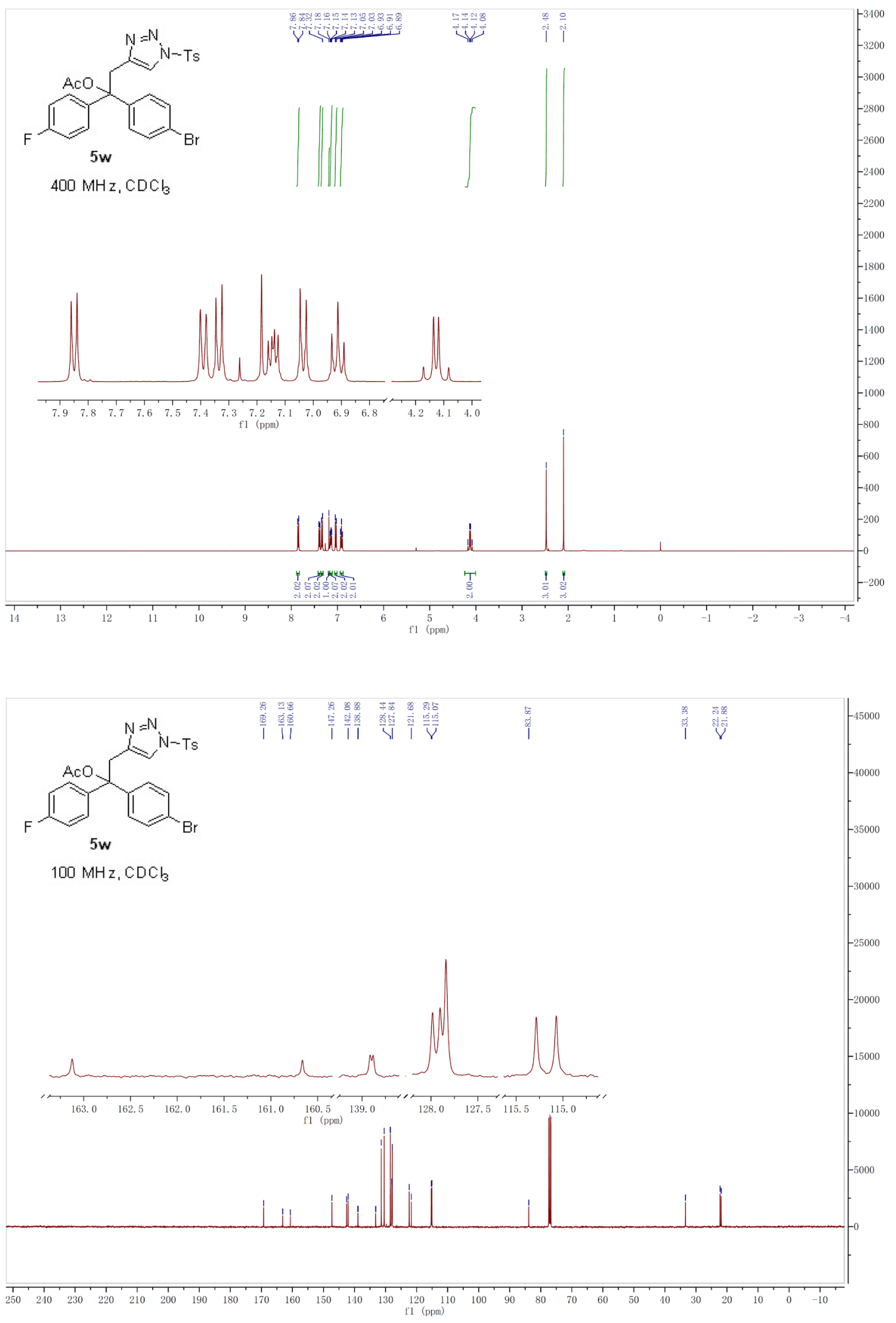

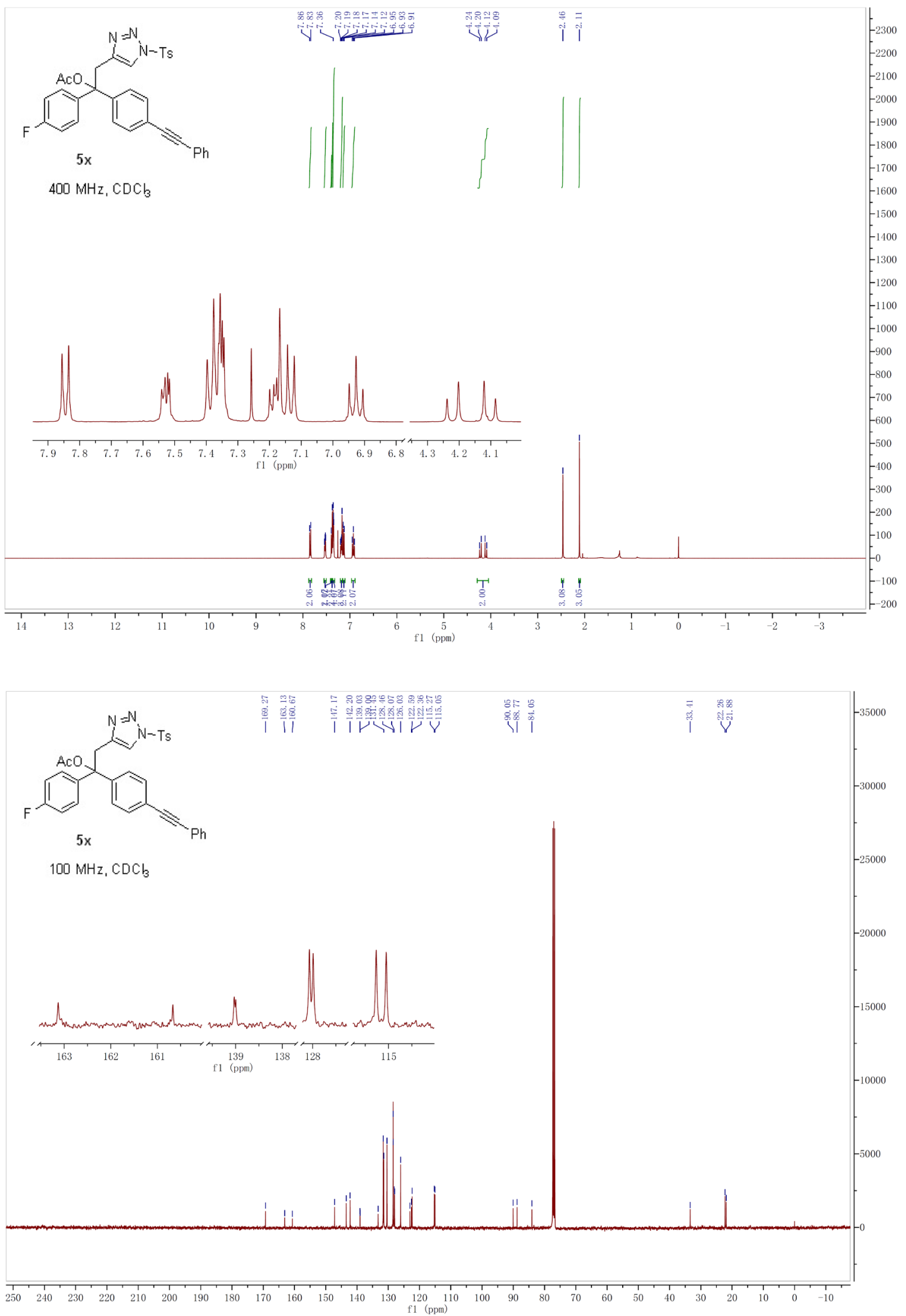

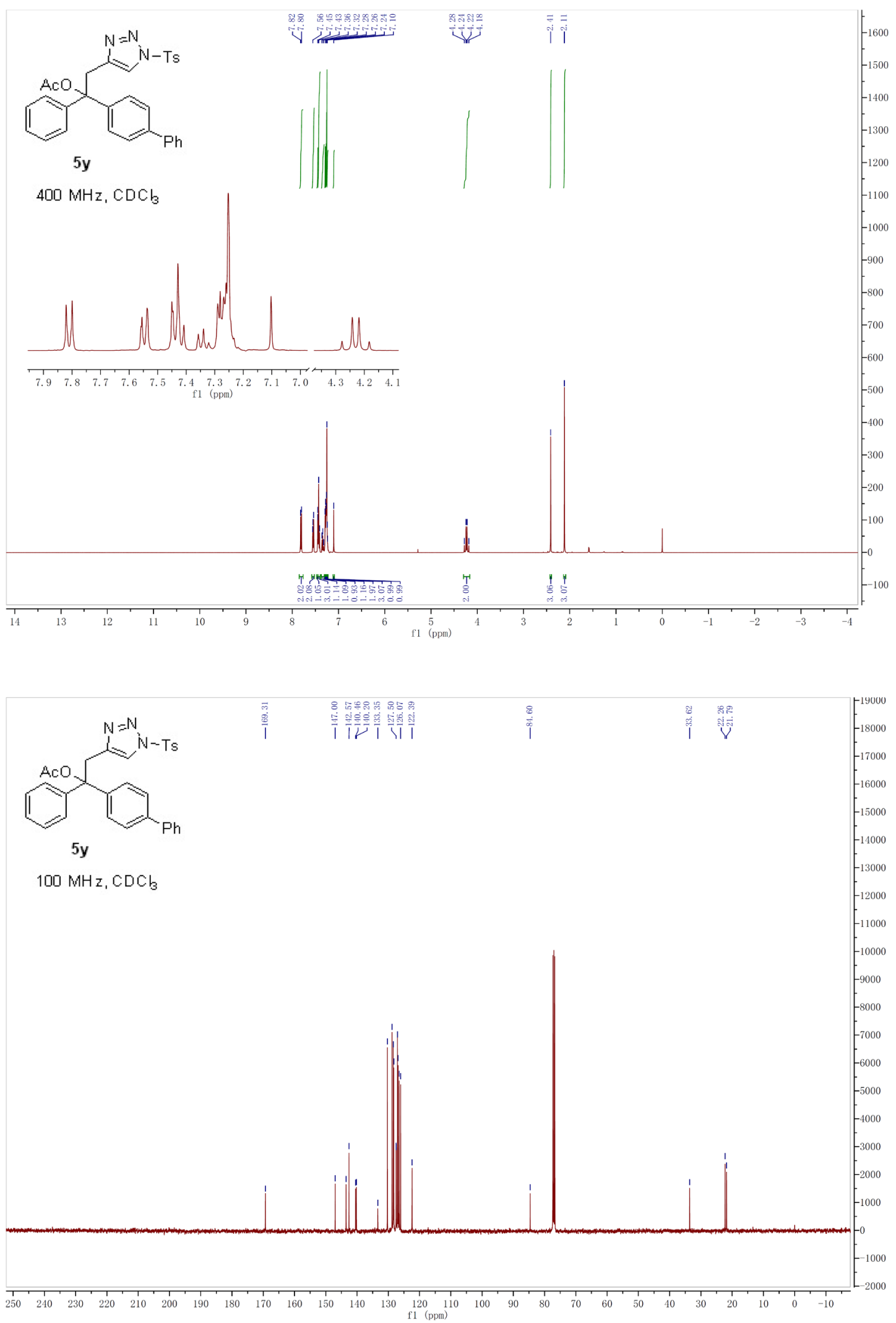


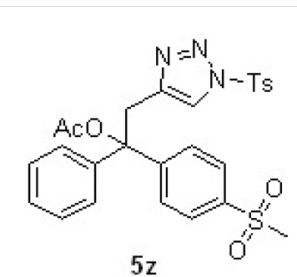

$400 \mathrm{MHz}, \mathrm{CDCl}_{3}$

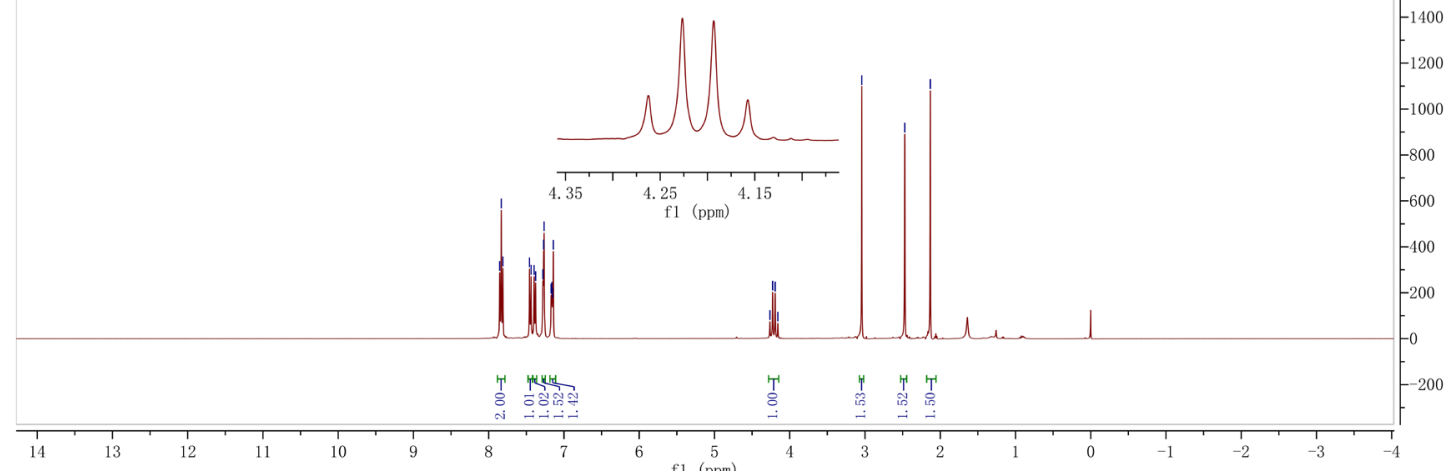<smiles></smiles>

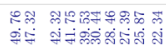

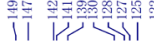

$100 \mathrm{MHz}, \mathrm{CDCl}_{3}$

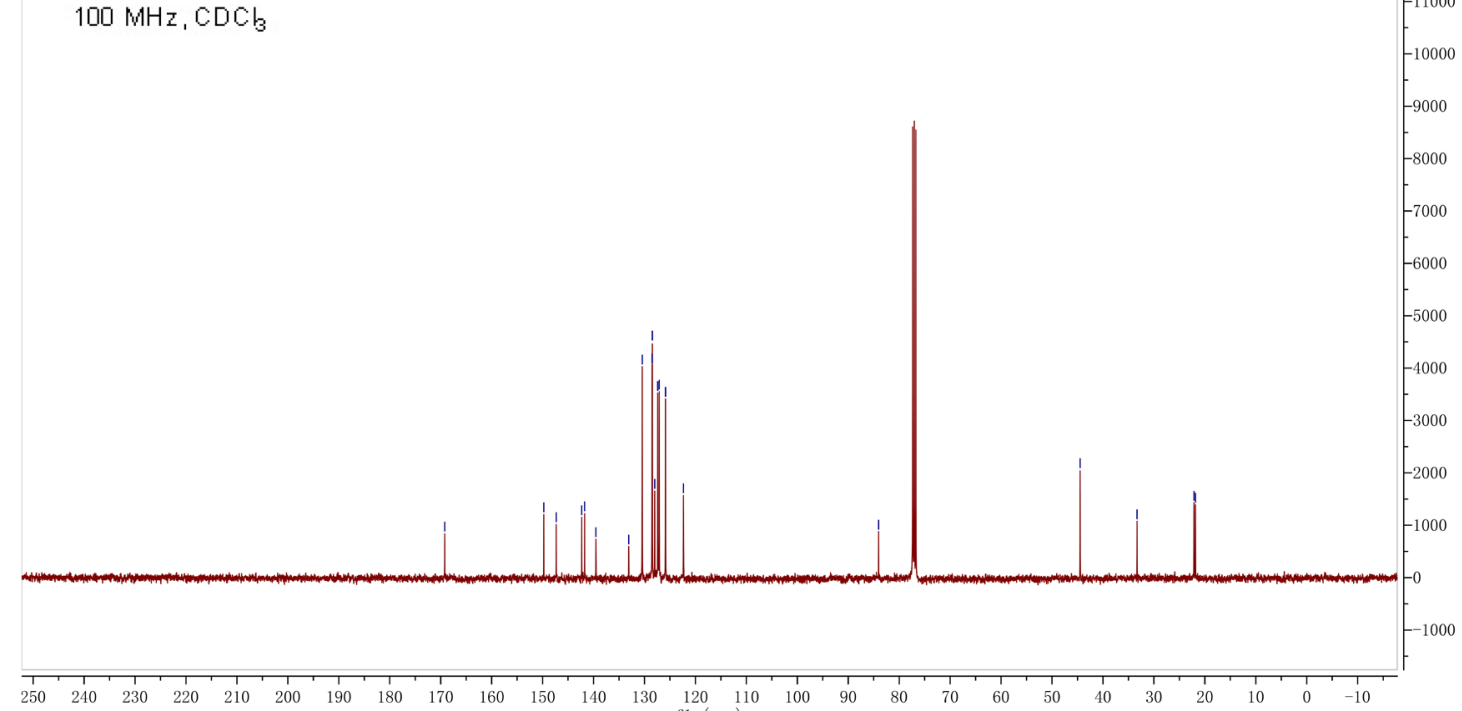




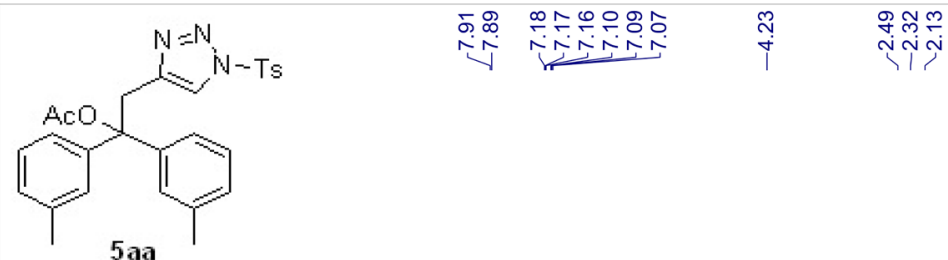

$400 \mathrm{MHz}, \mathrm{CDCl}$
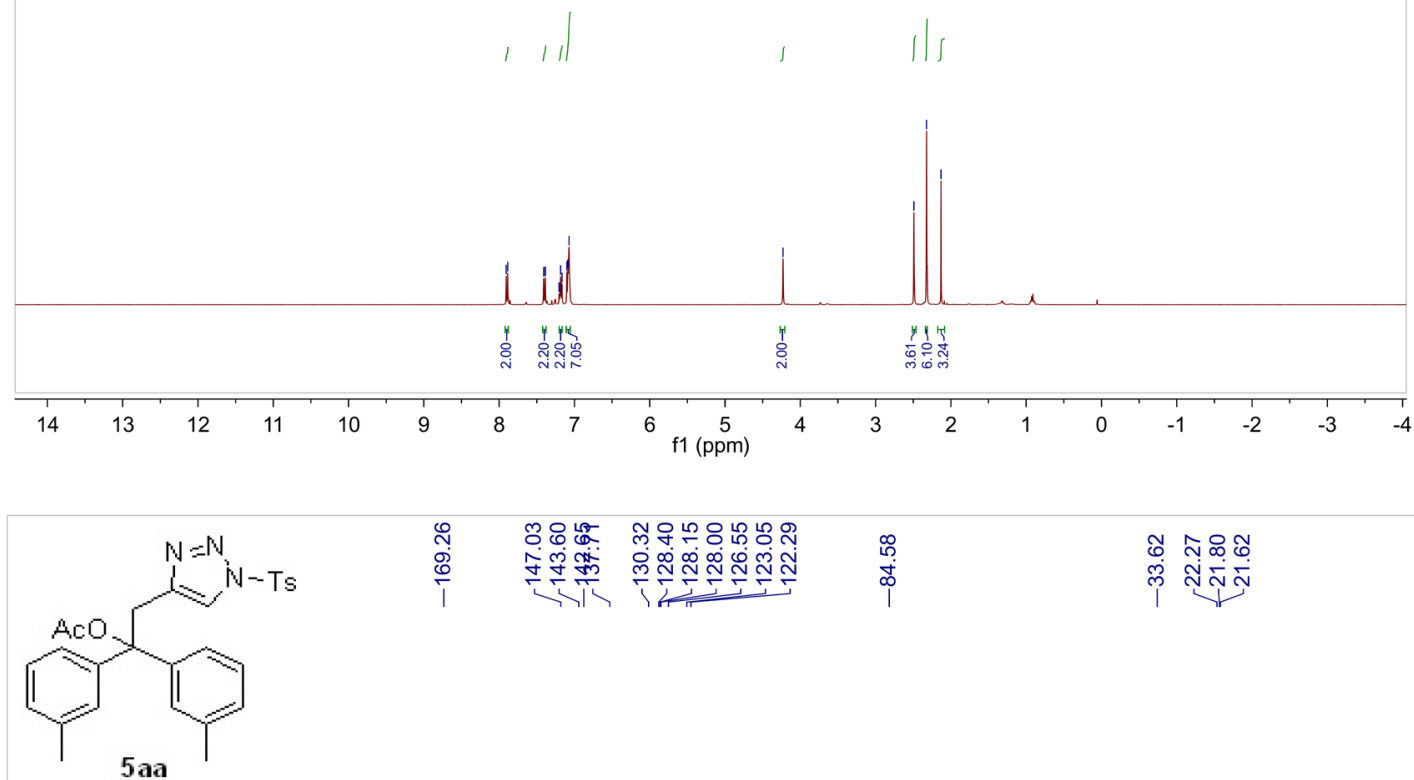

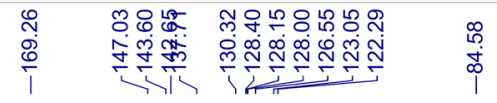

ชิ กิธ

กั่

$400 \mathrm{MHz}, \mathrm{CDCl}_{3}$

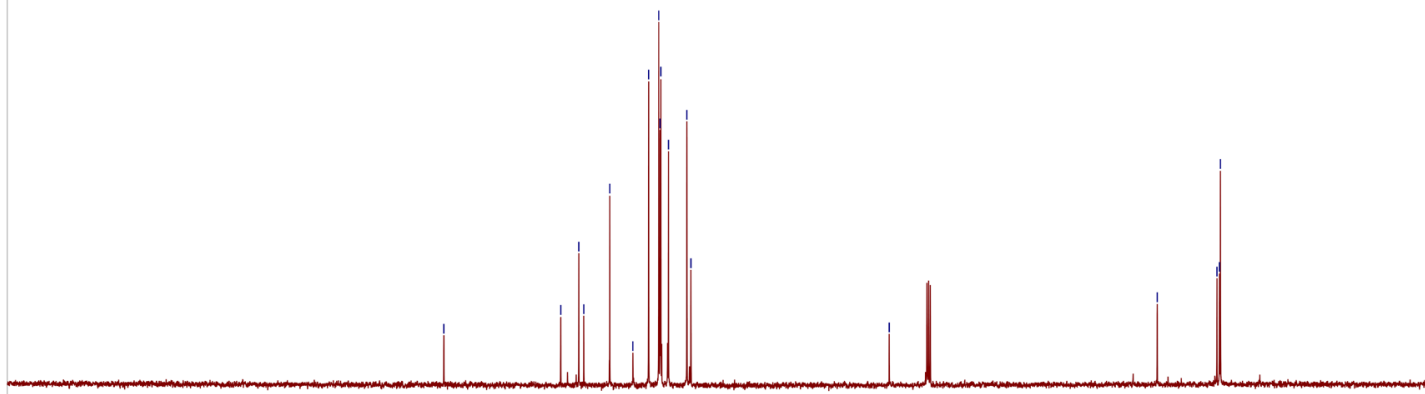

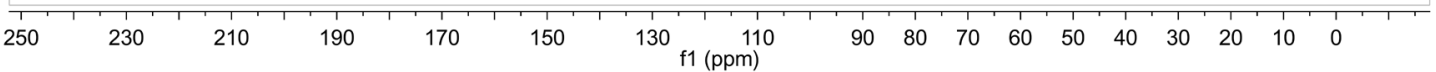




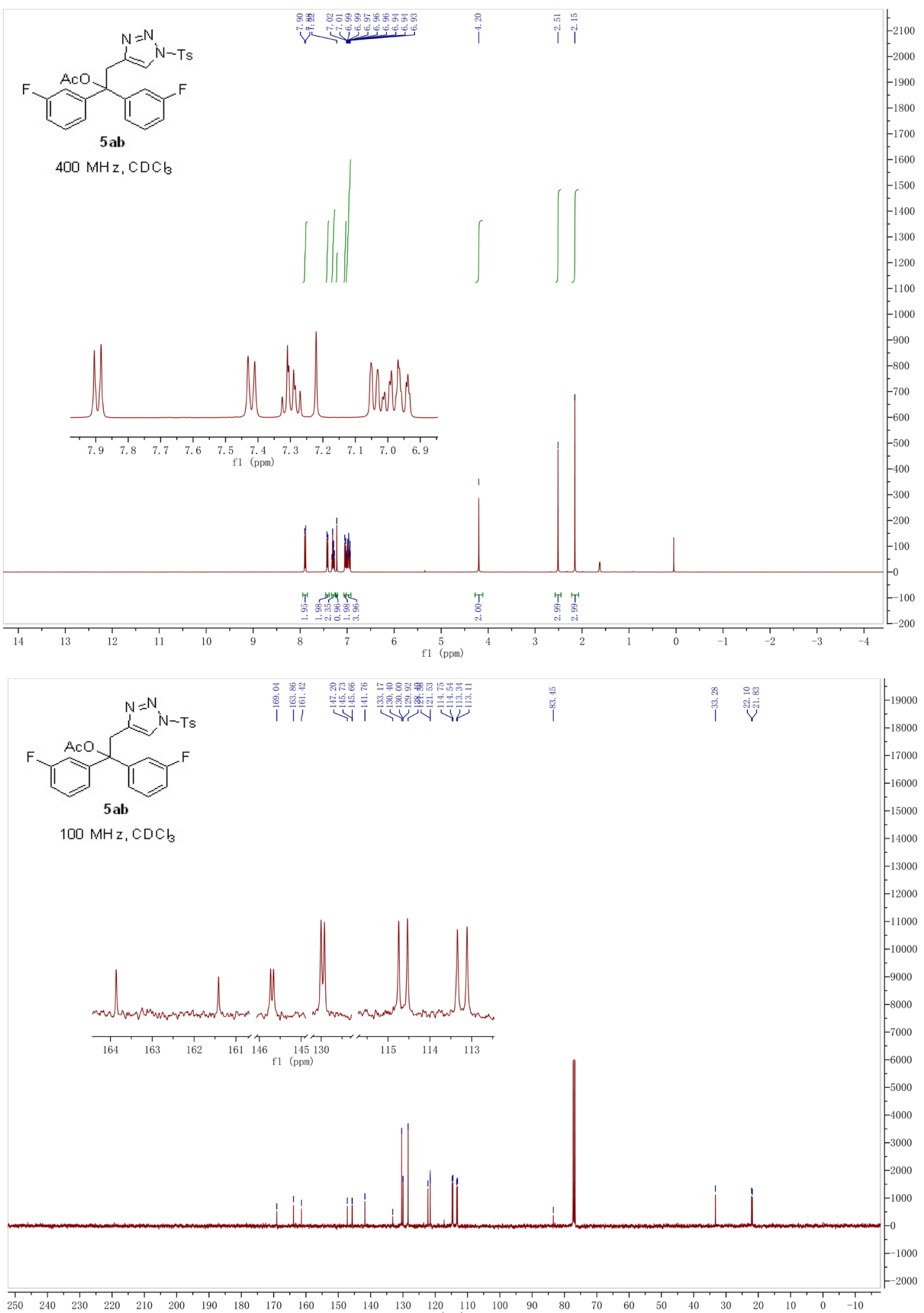




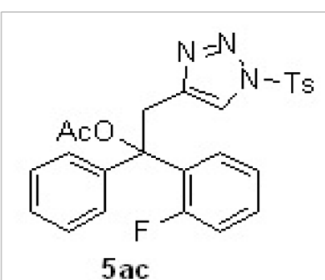

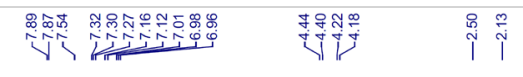

$400 \mathrm{MHz}, \mathrm{CDCl}_{3}$
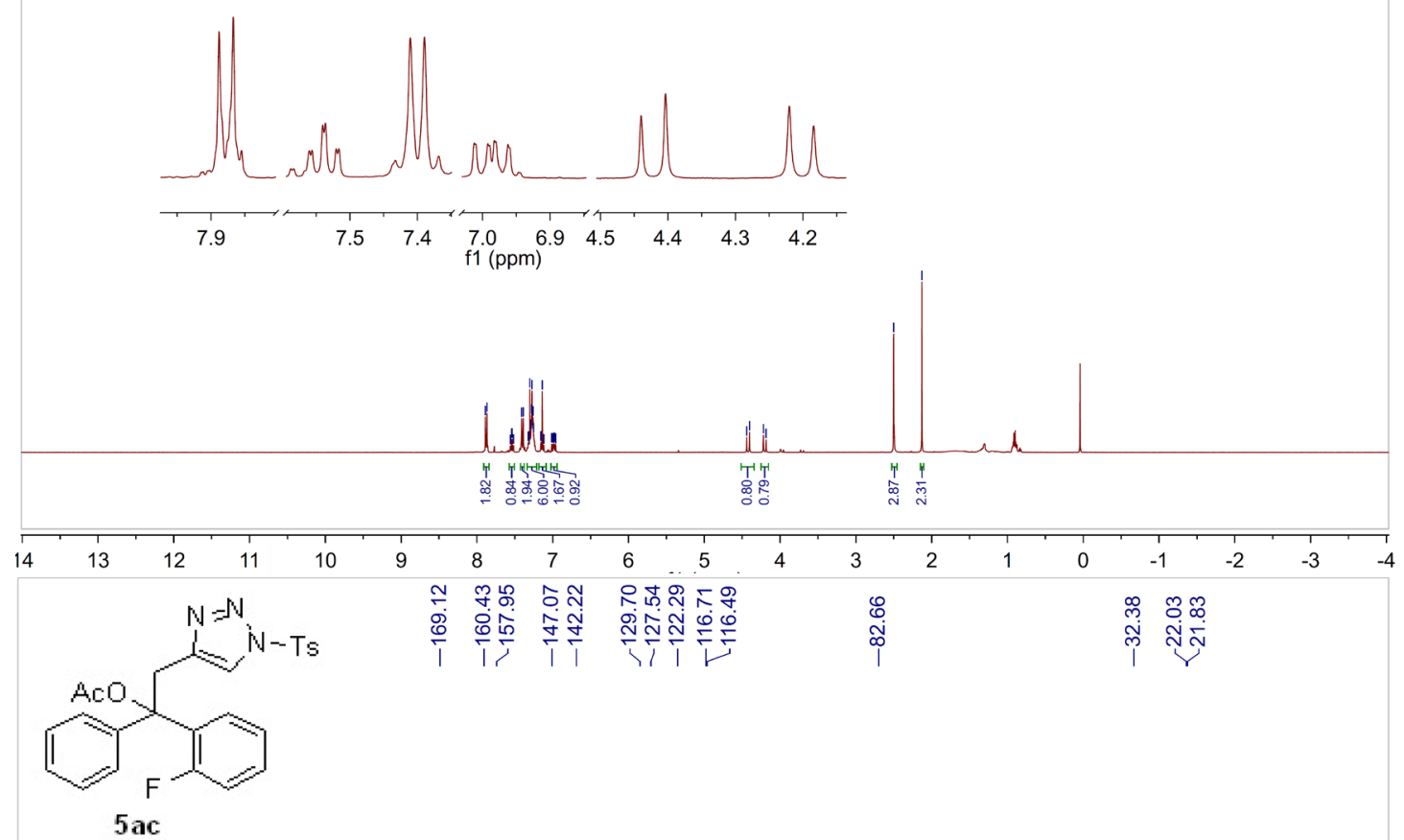

$100 \mathrm{MHz}_{1} \mathrm{CDCl}_{3}$
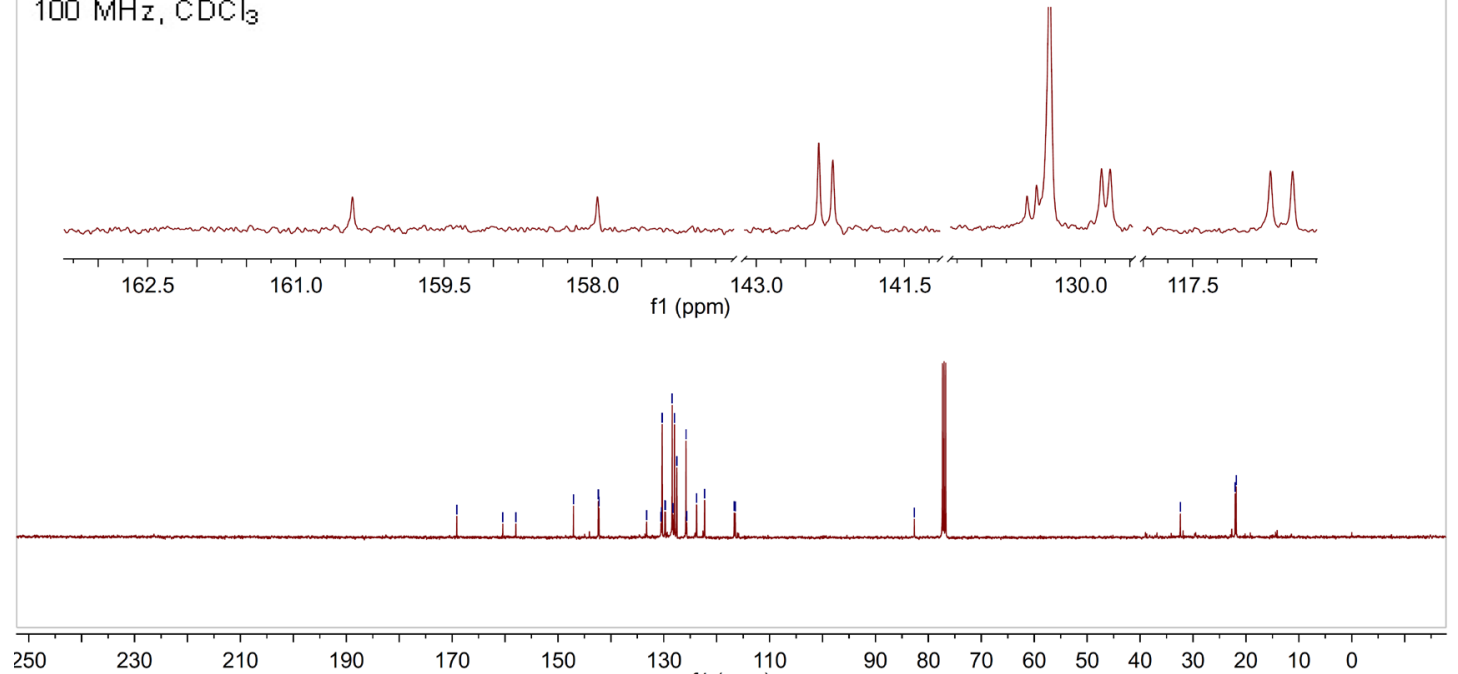

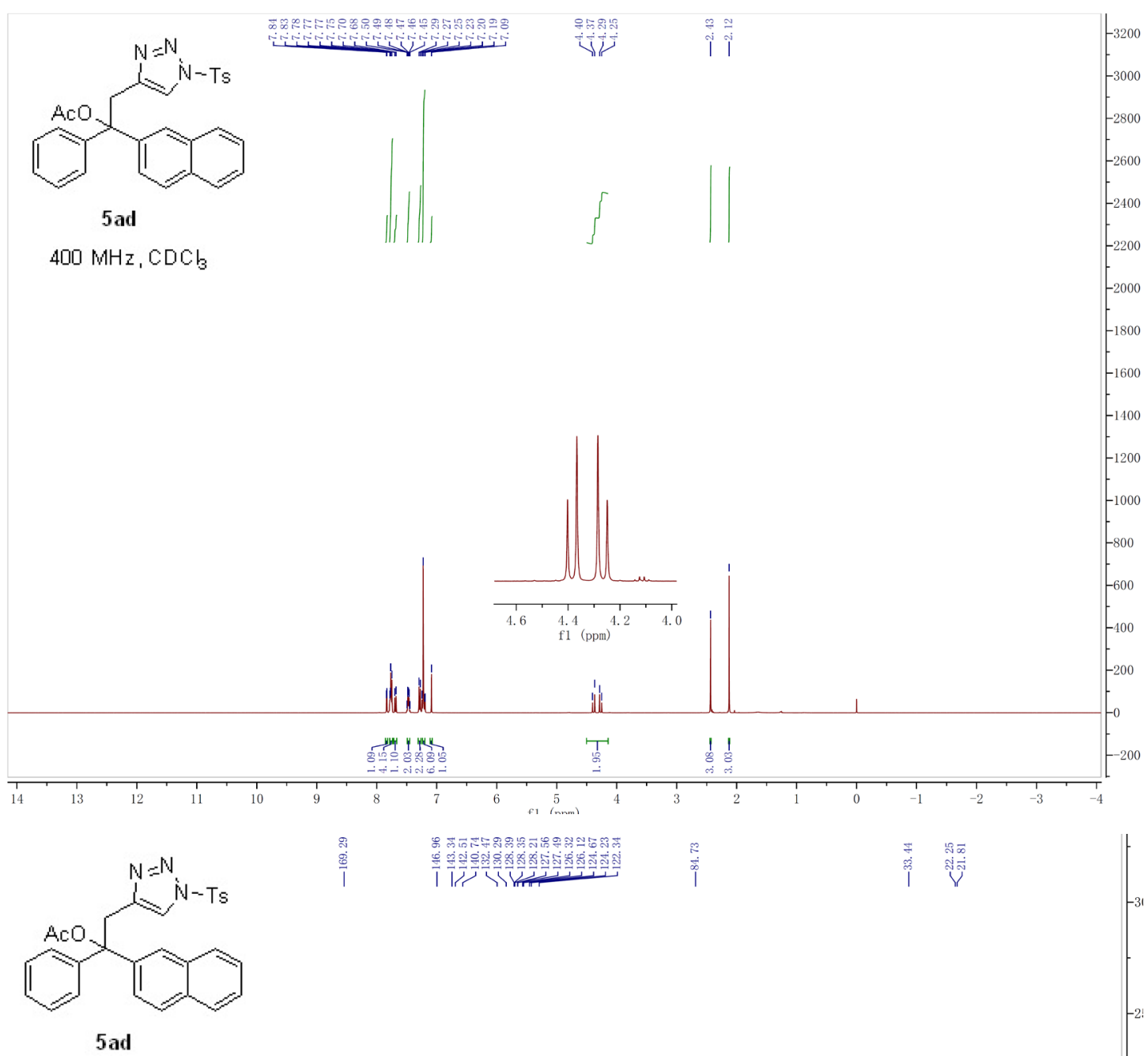

$100 \mathrm{MHz}, \mathrm{CDCb}_{3}$

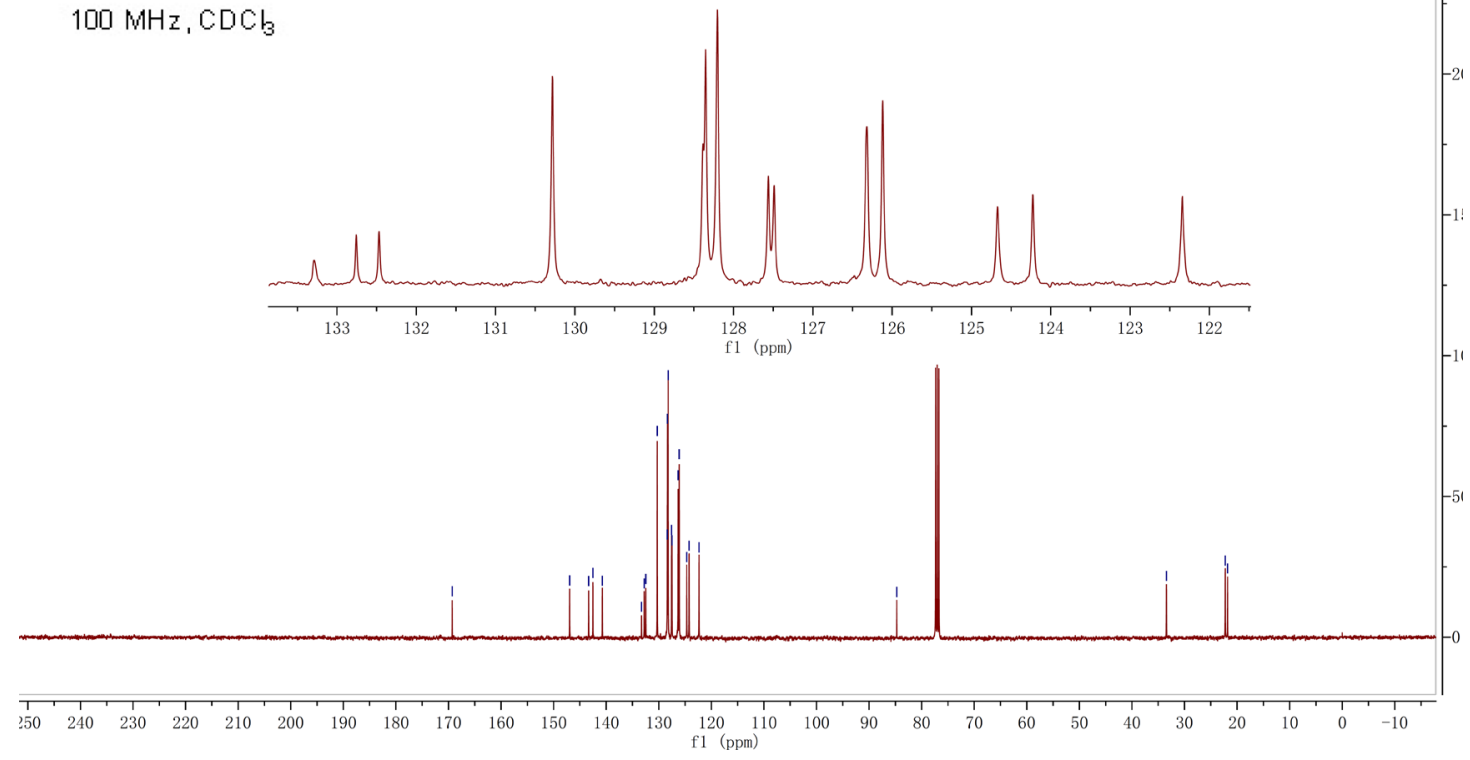




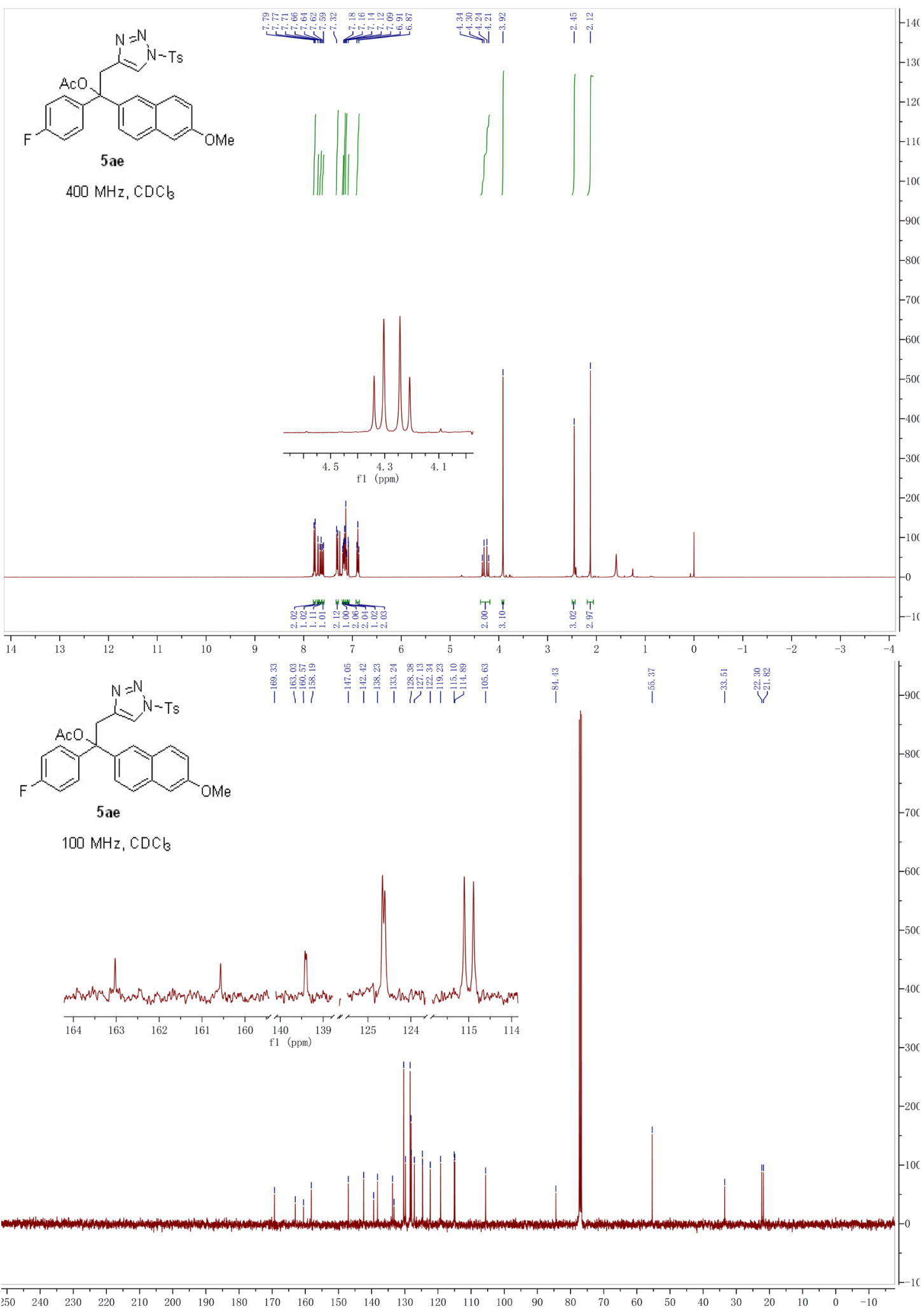



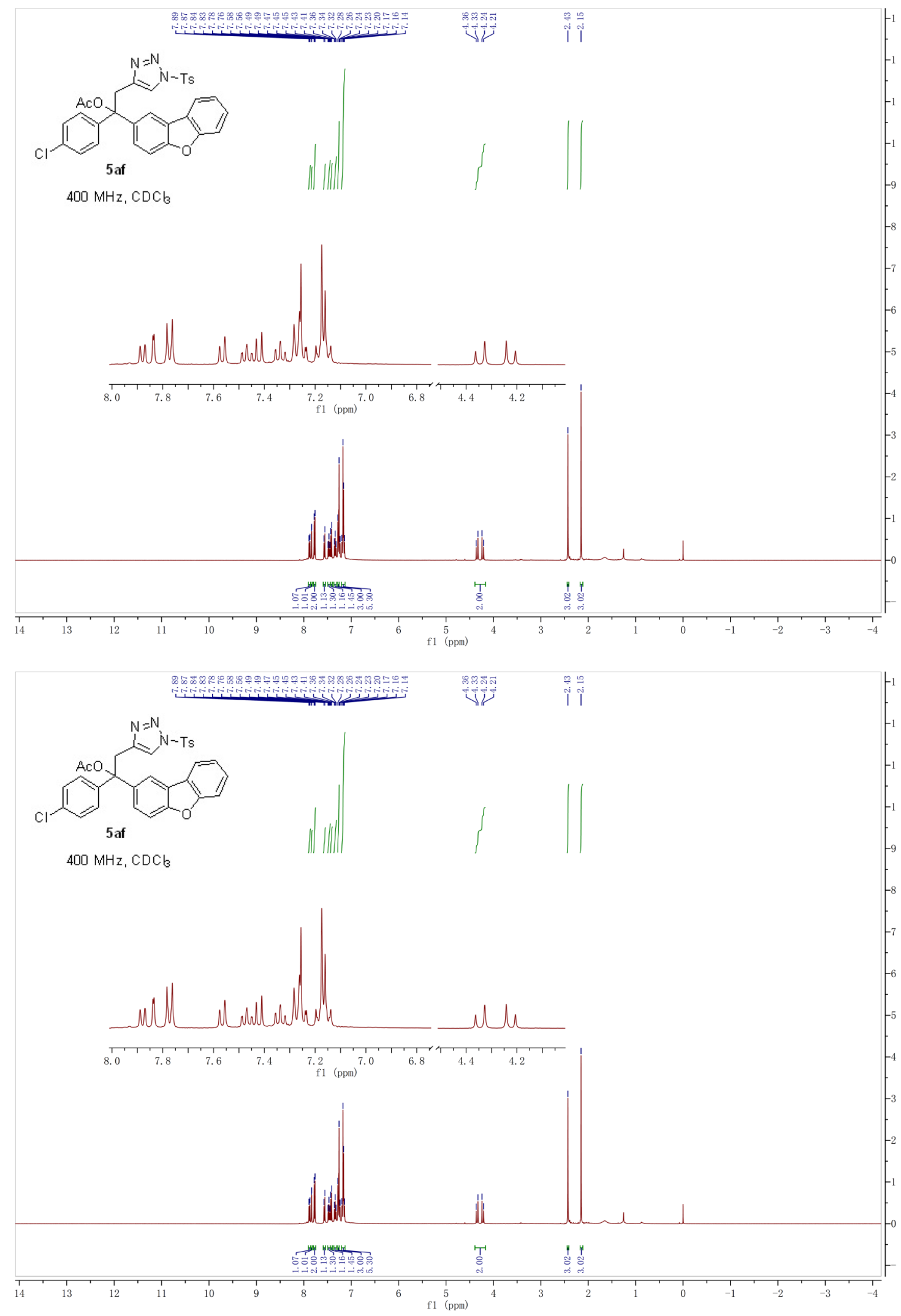


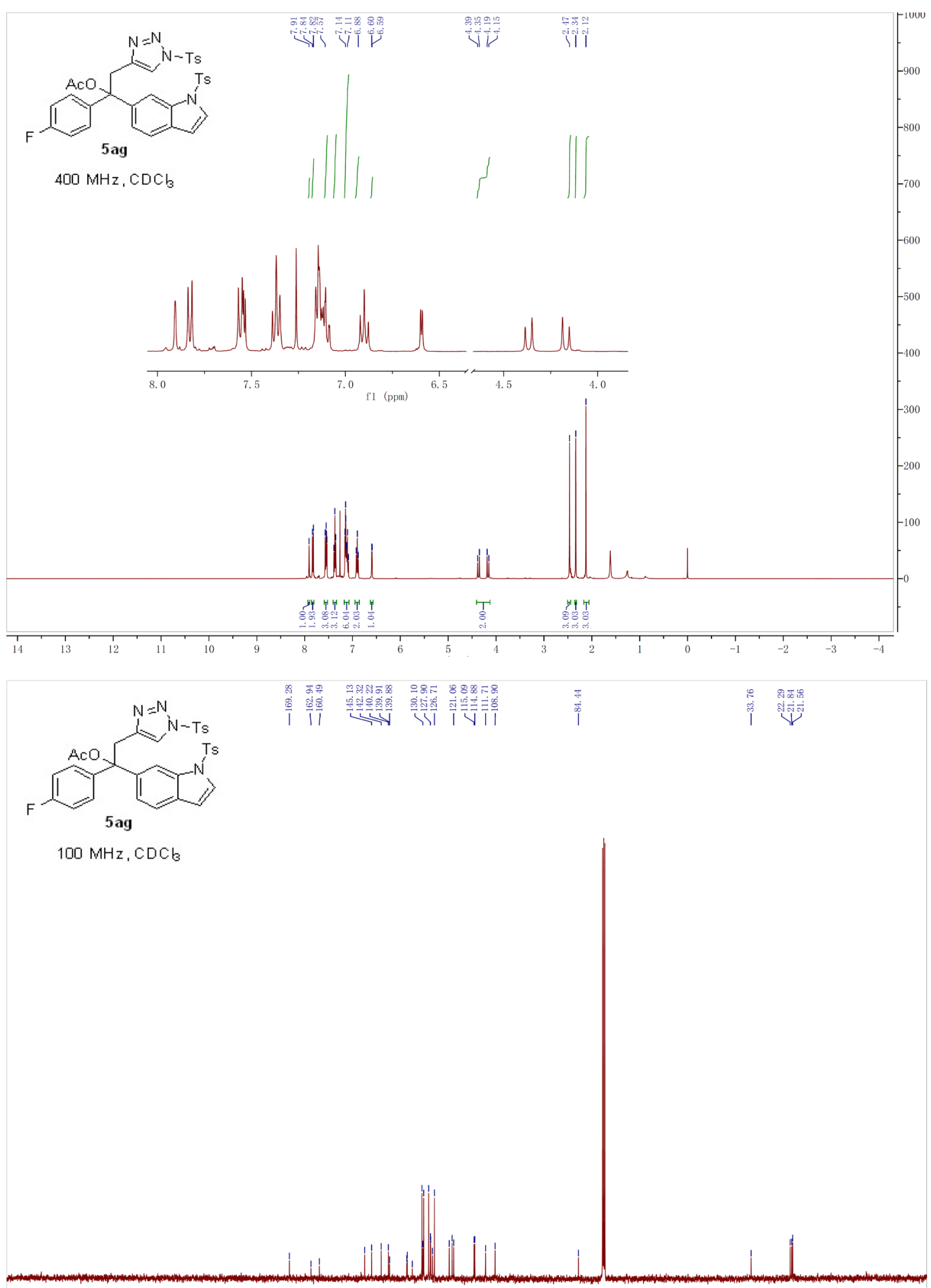

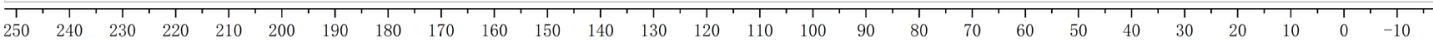




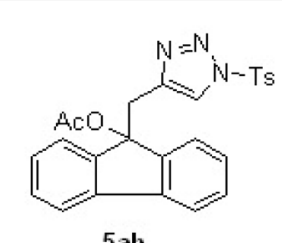

5 ah

$400 \mathrm{MHz}, \mathrm{CDCl}_{3}$

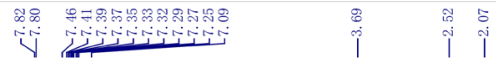
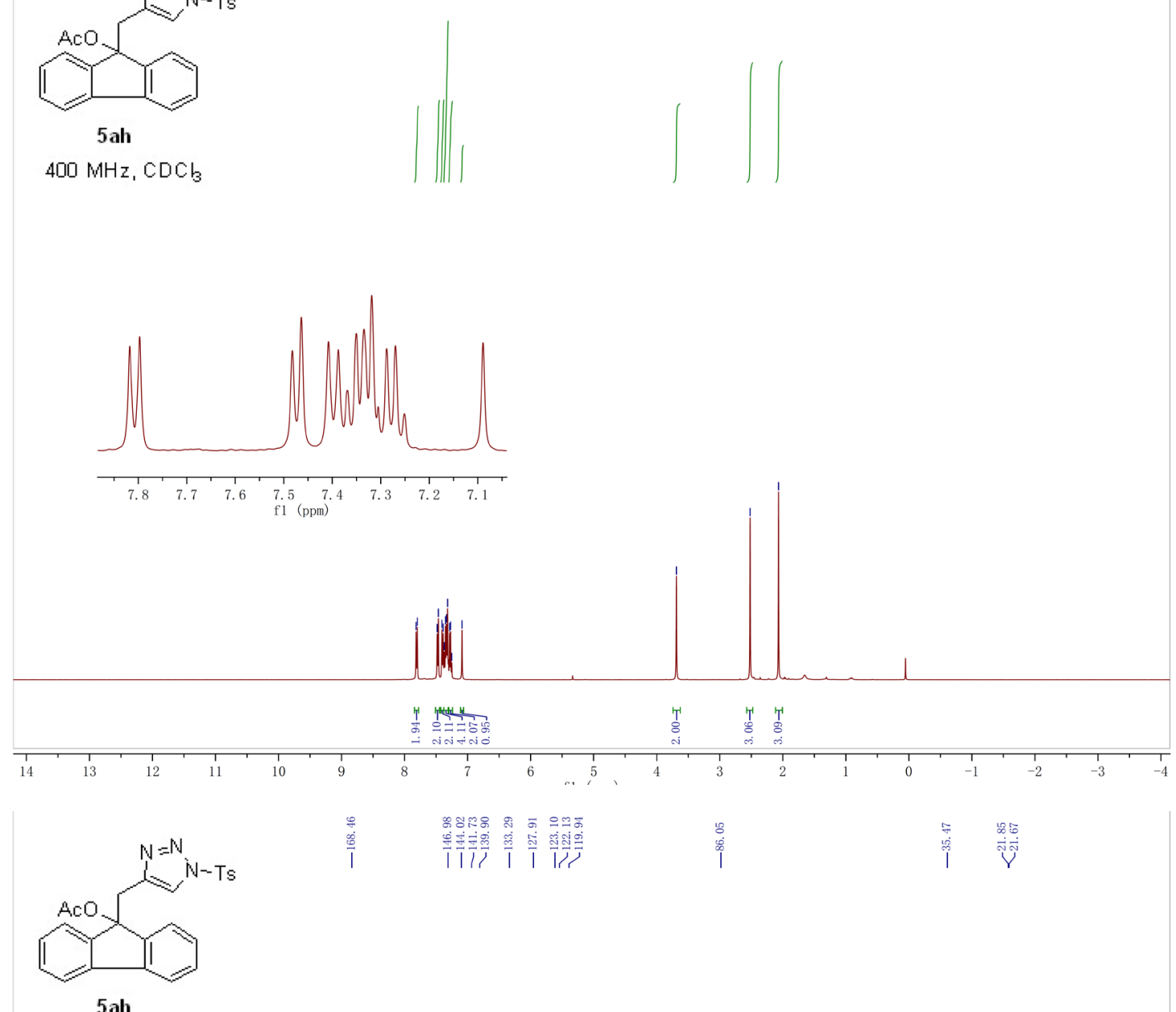

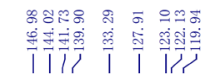

18
18
1

ป

$100 \mathrm{MHz}_{1} \mathrm{CDCl}_{3}$

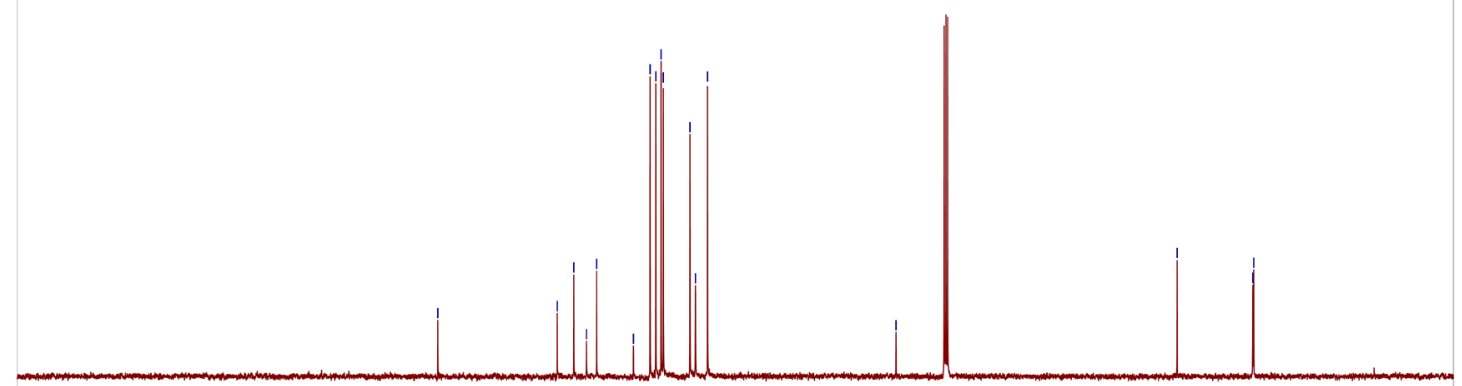

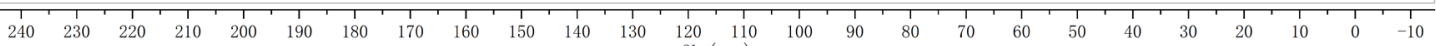




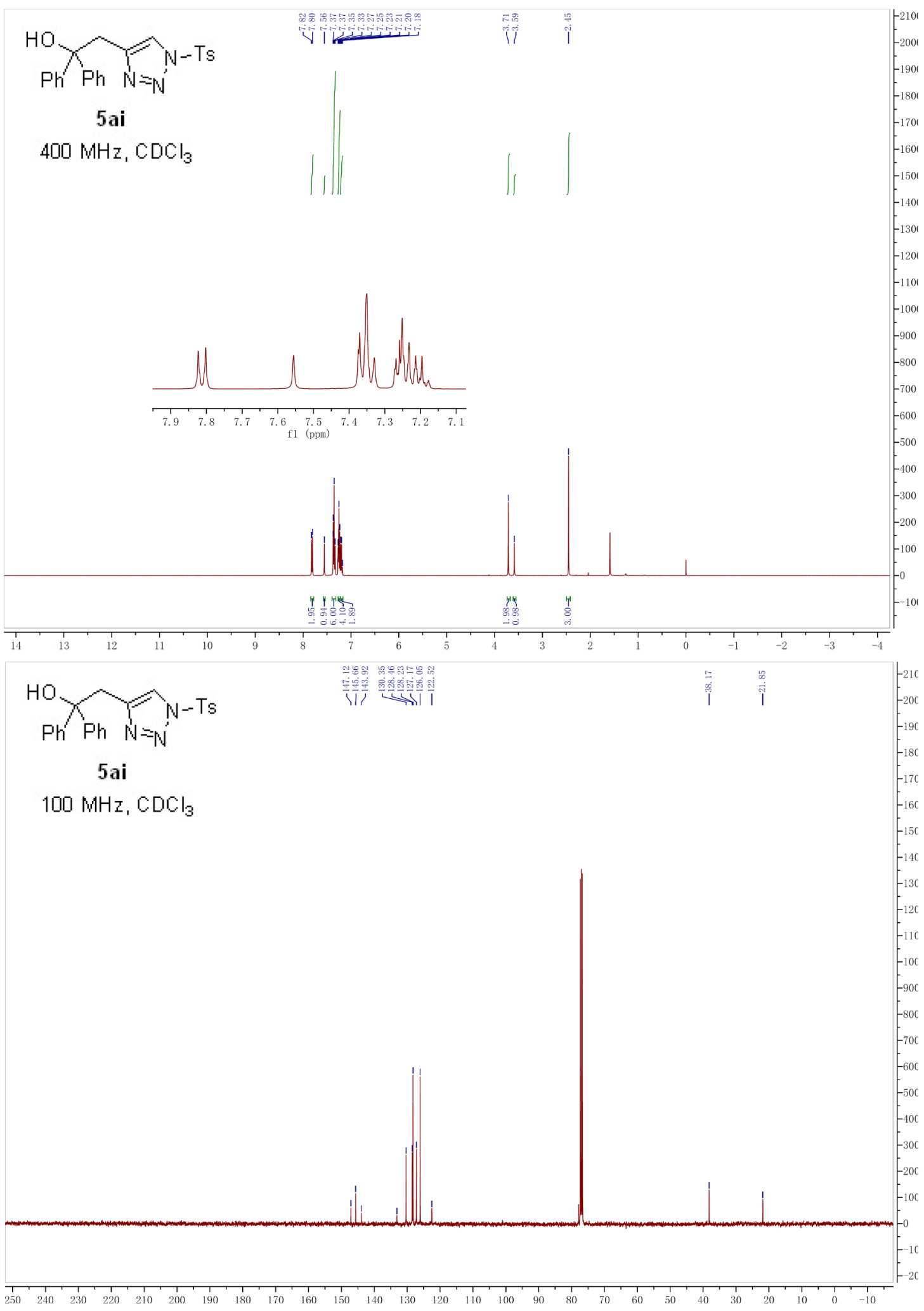




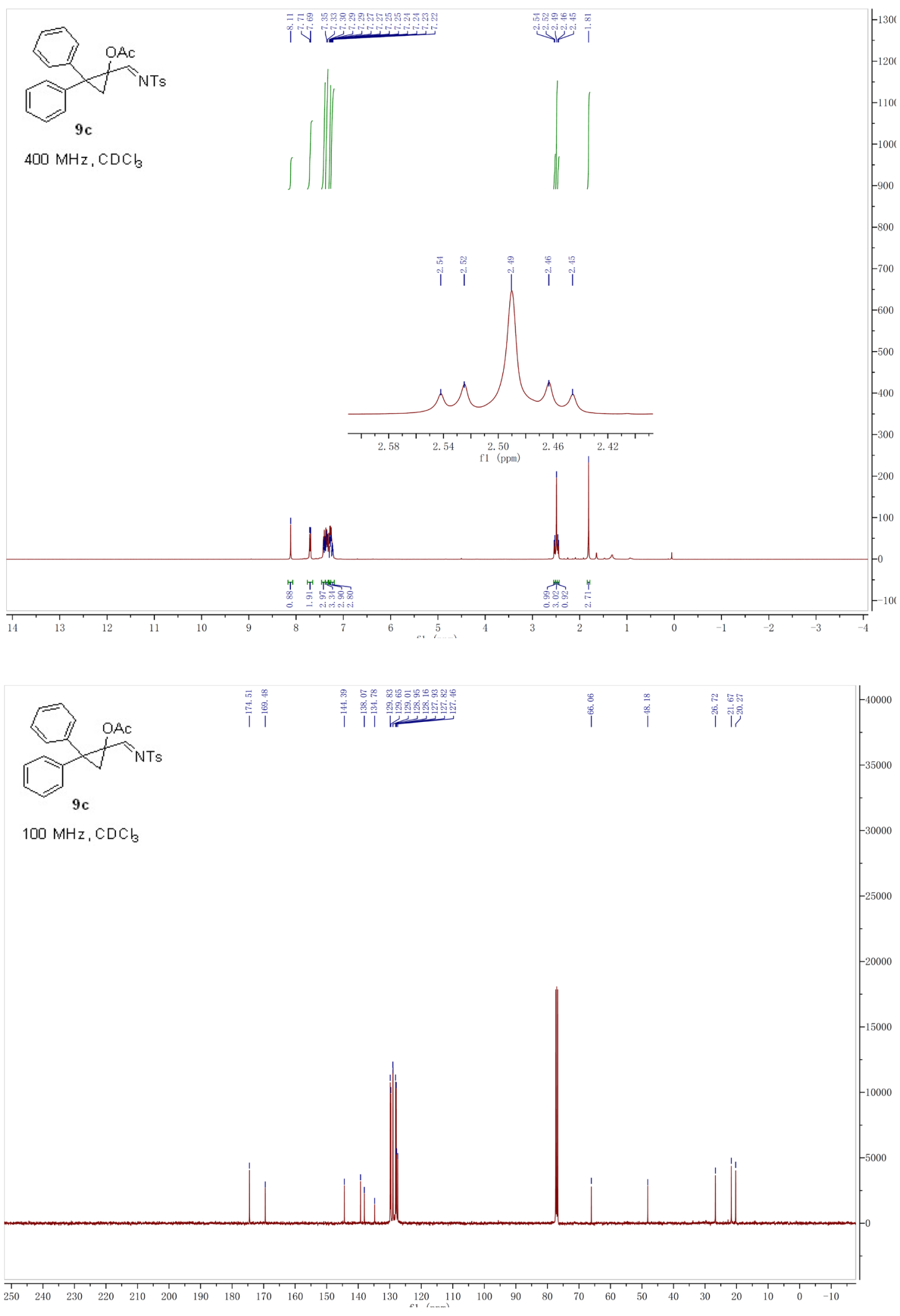



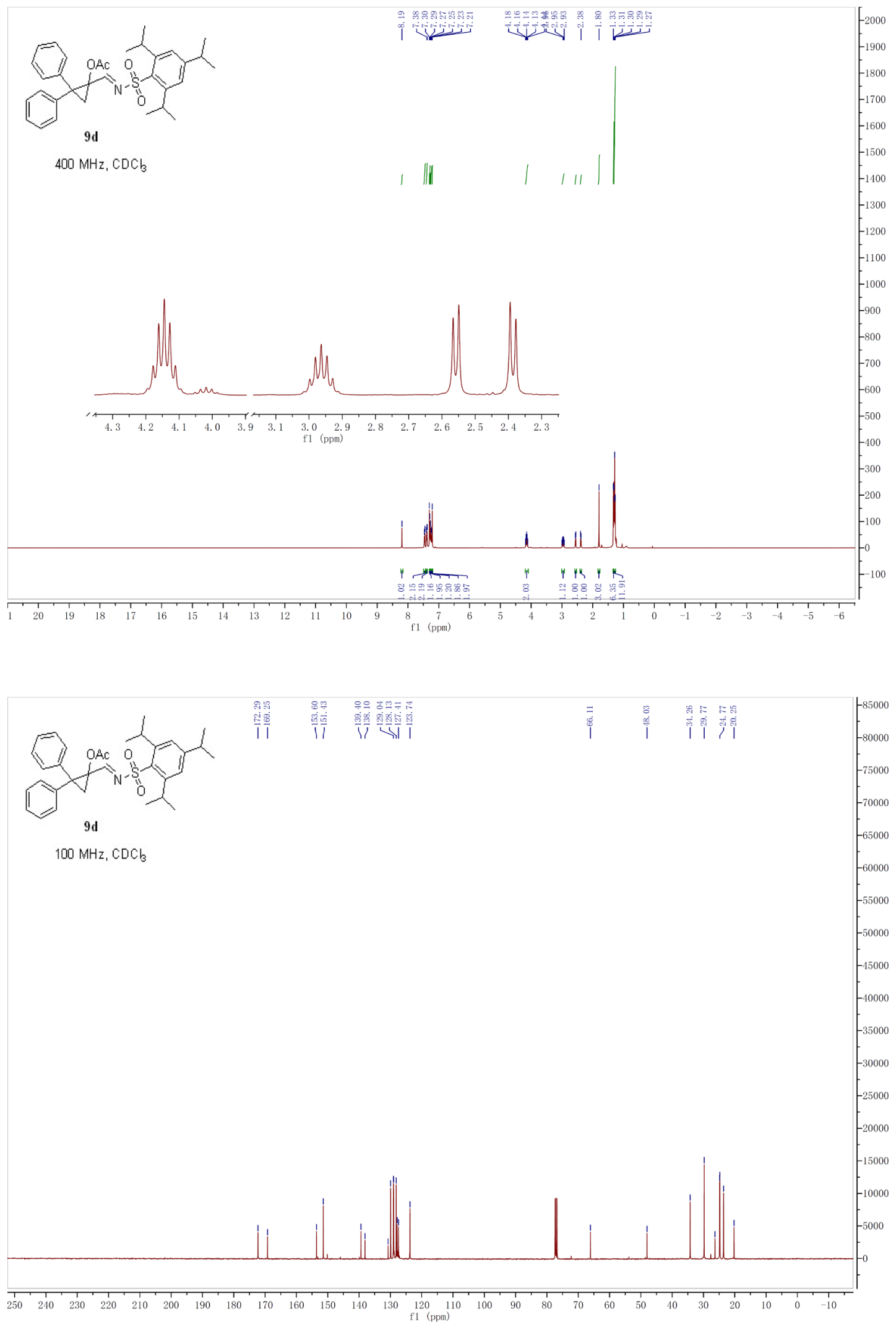

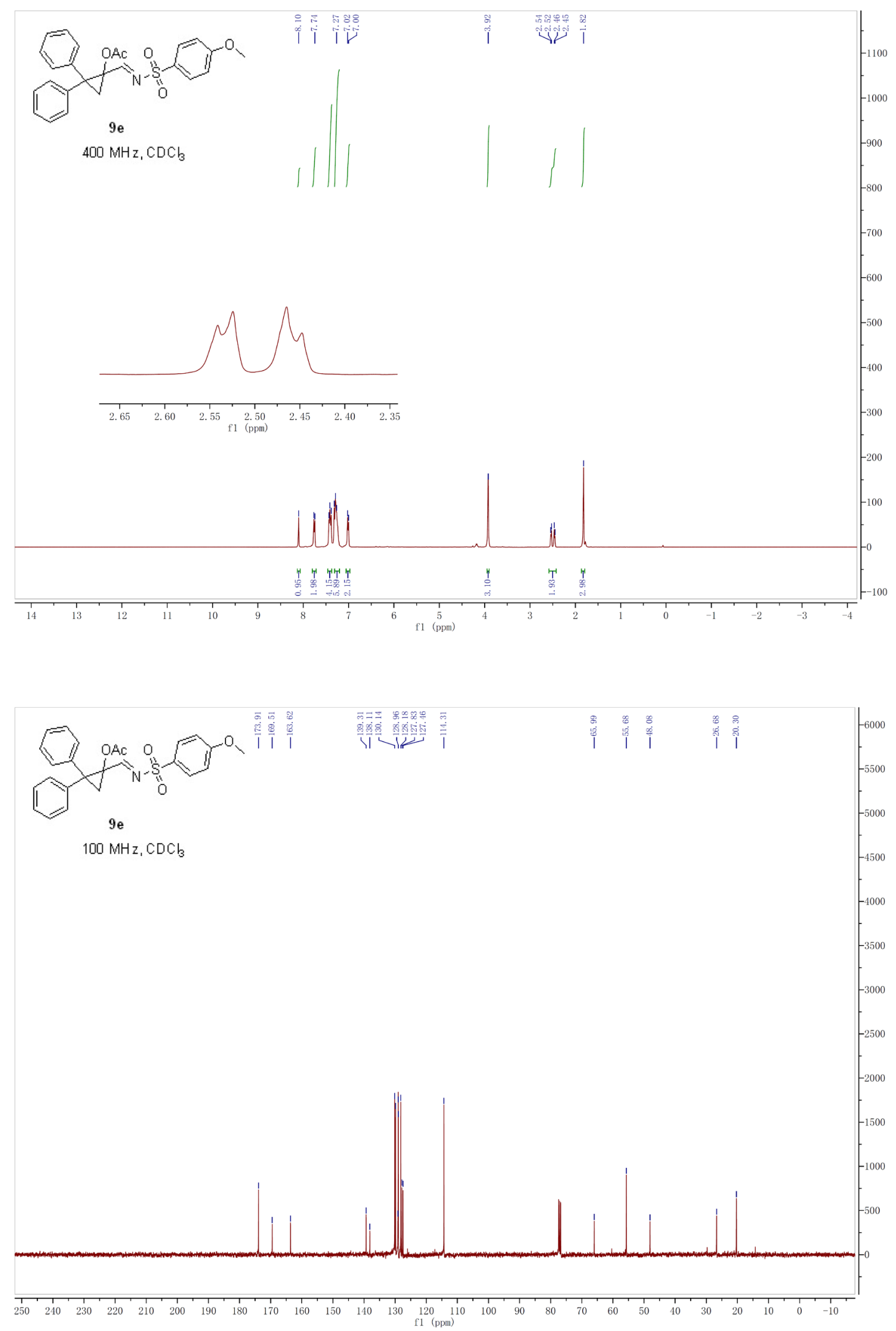

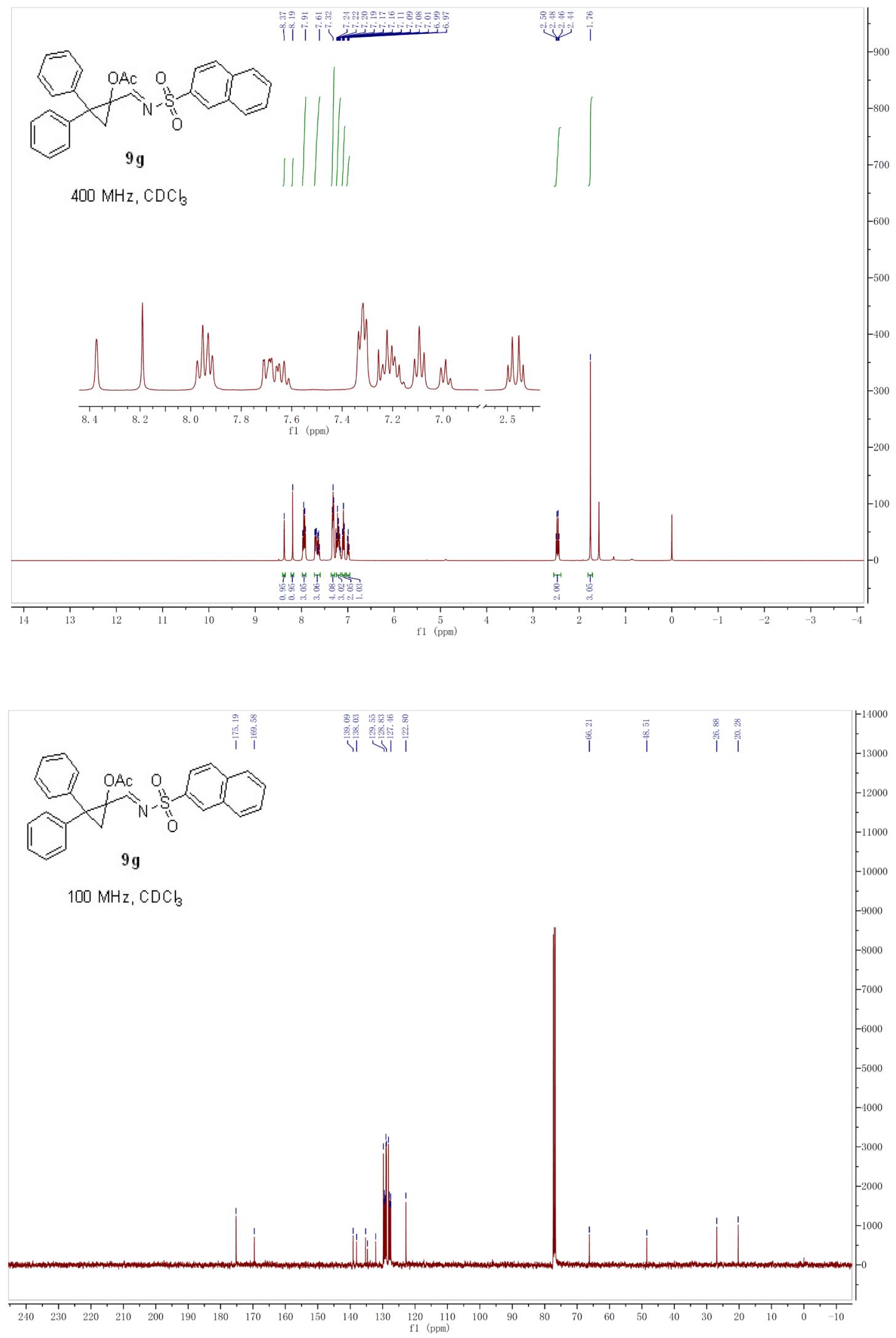


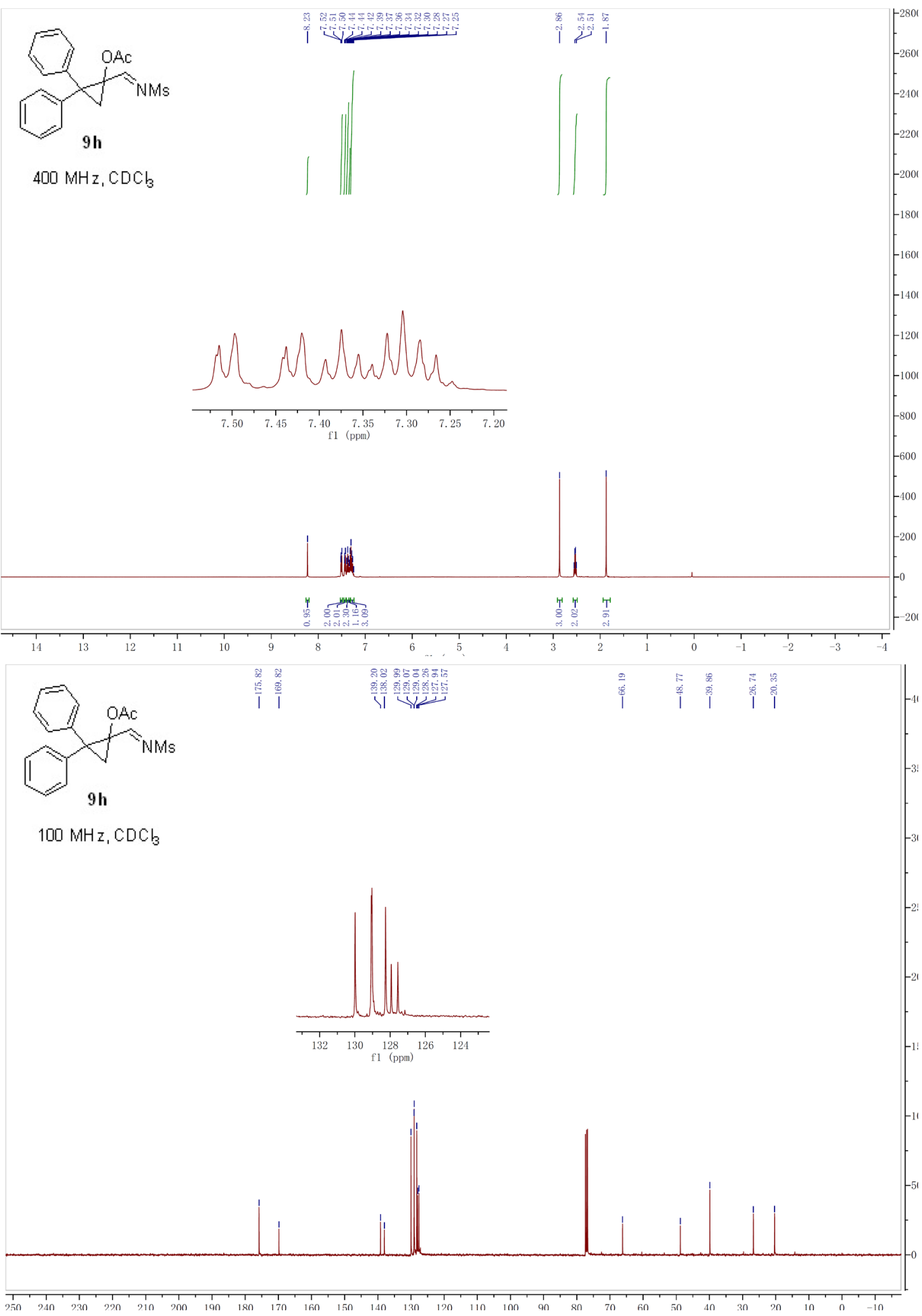



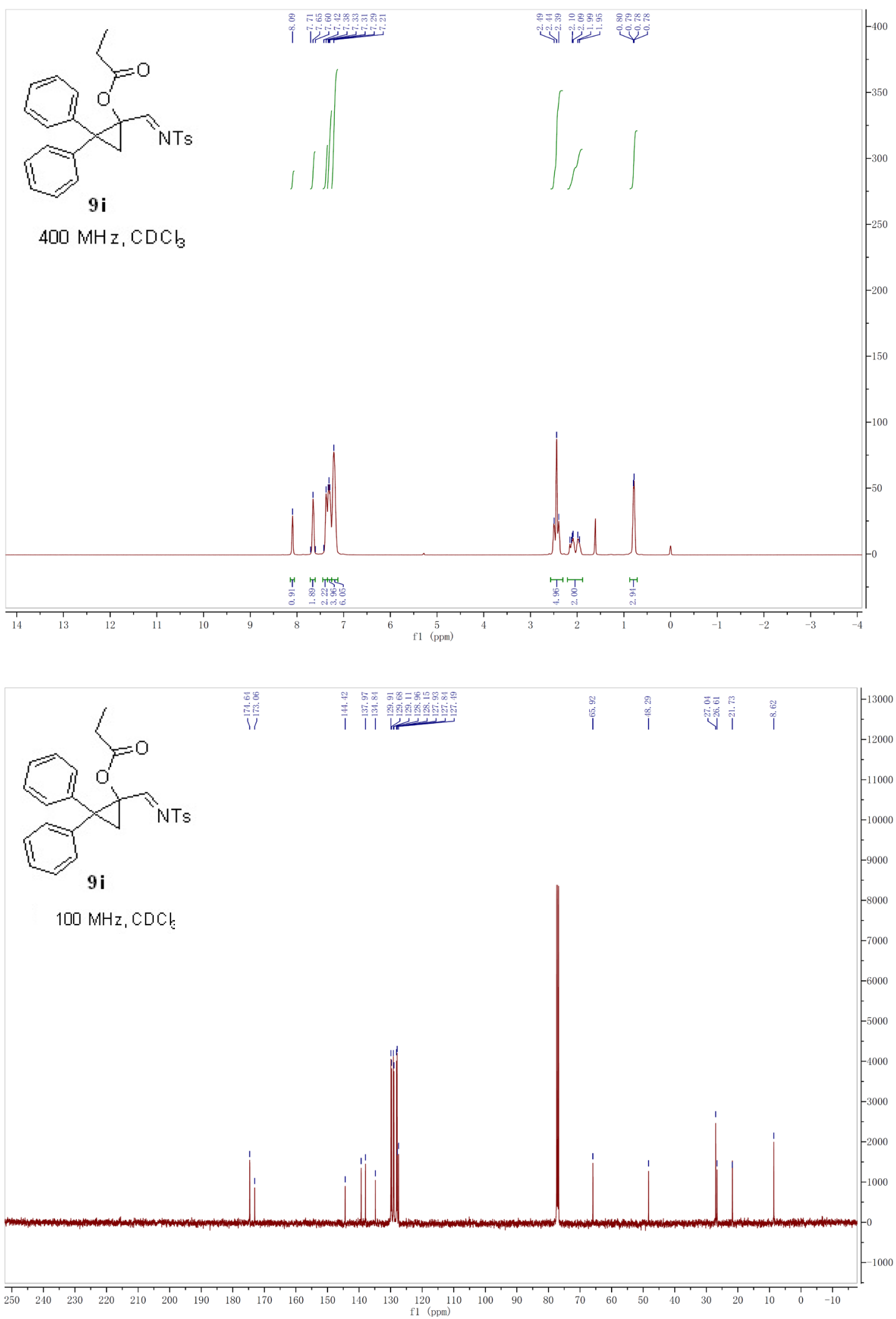

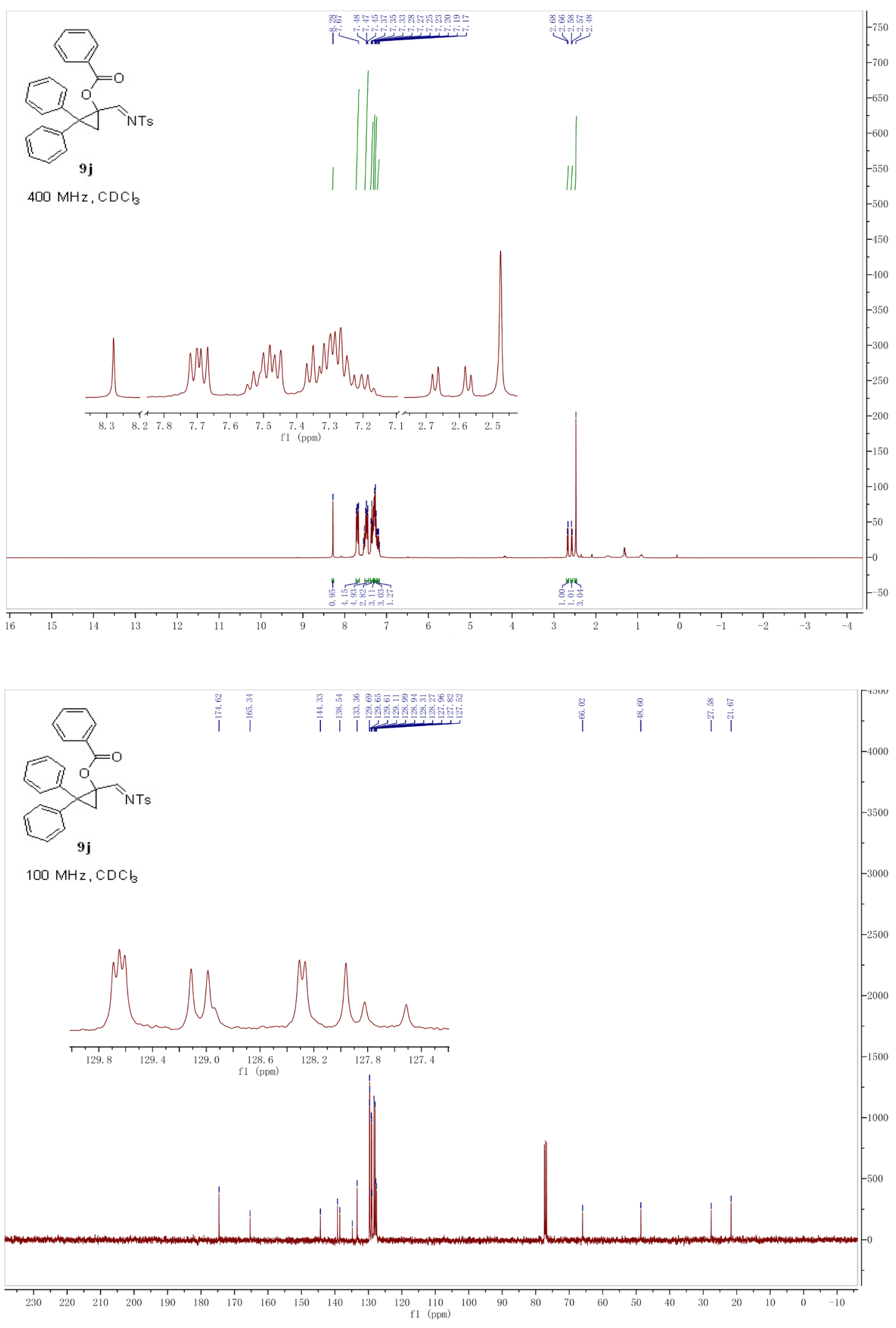

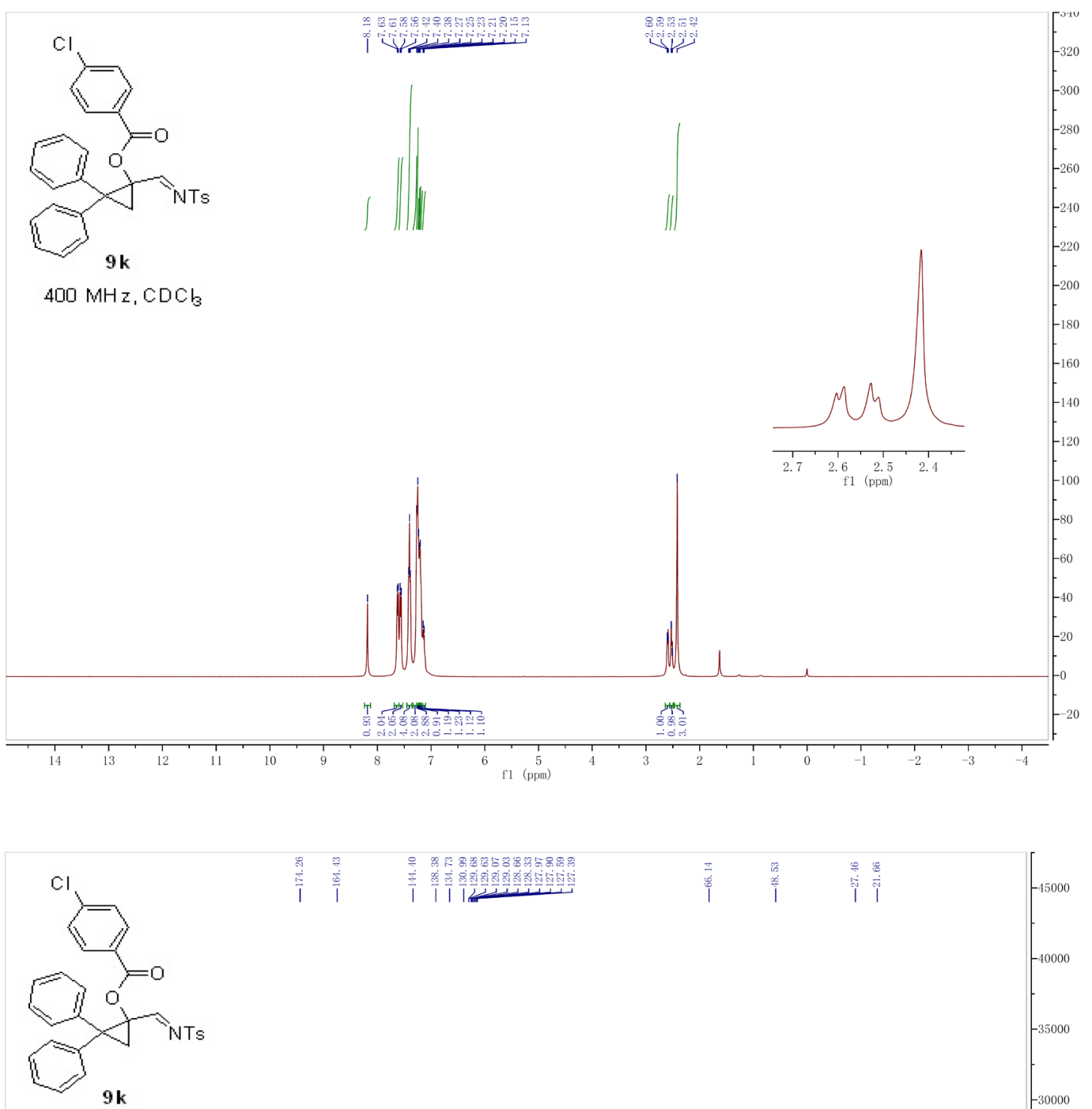

$100 \mathrm{MHz}, \mathrm{CDCl}_{3}$
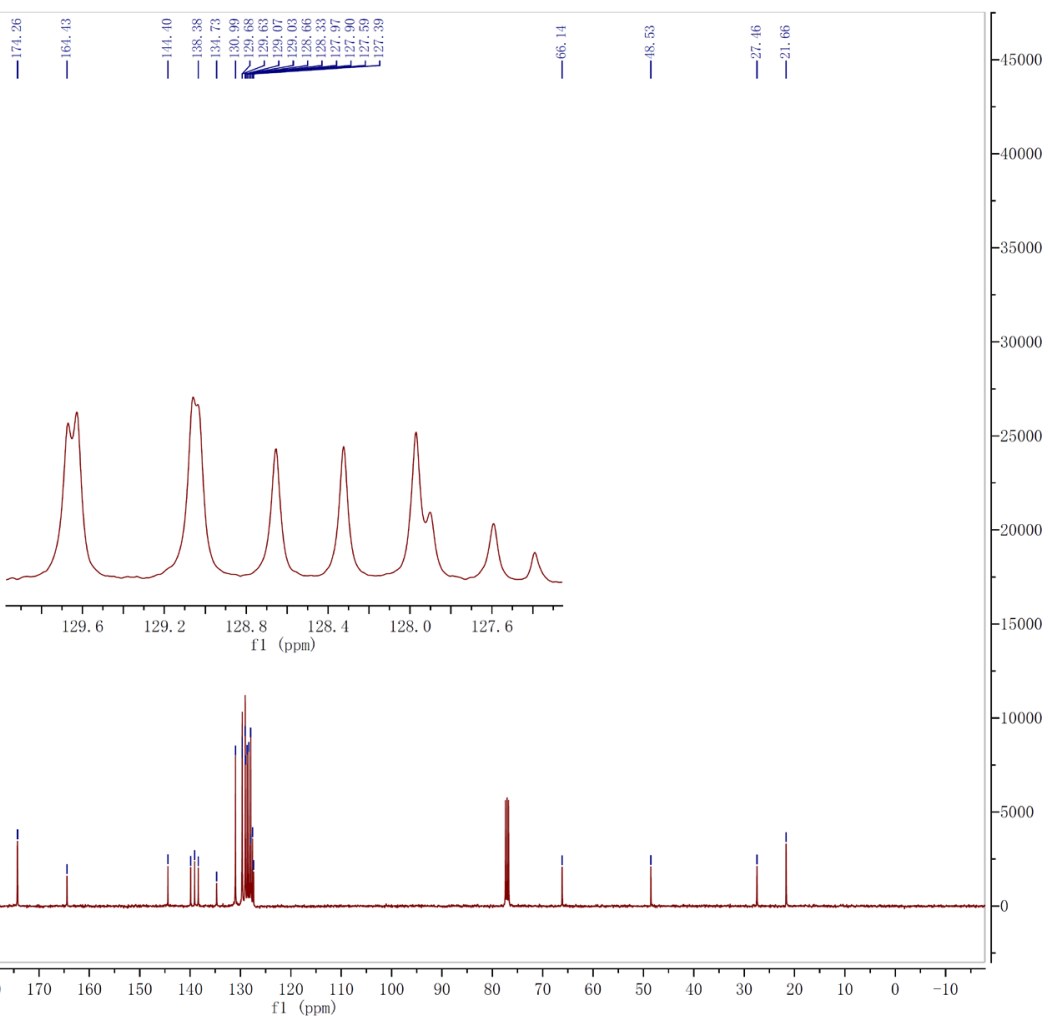

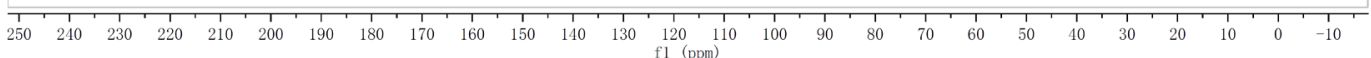



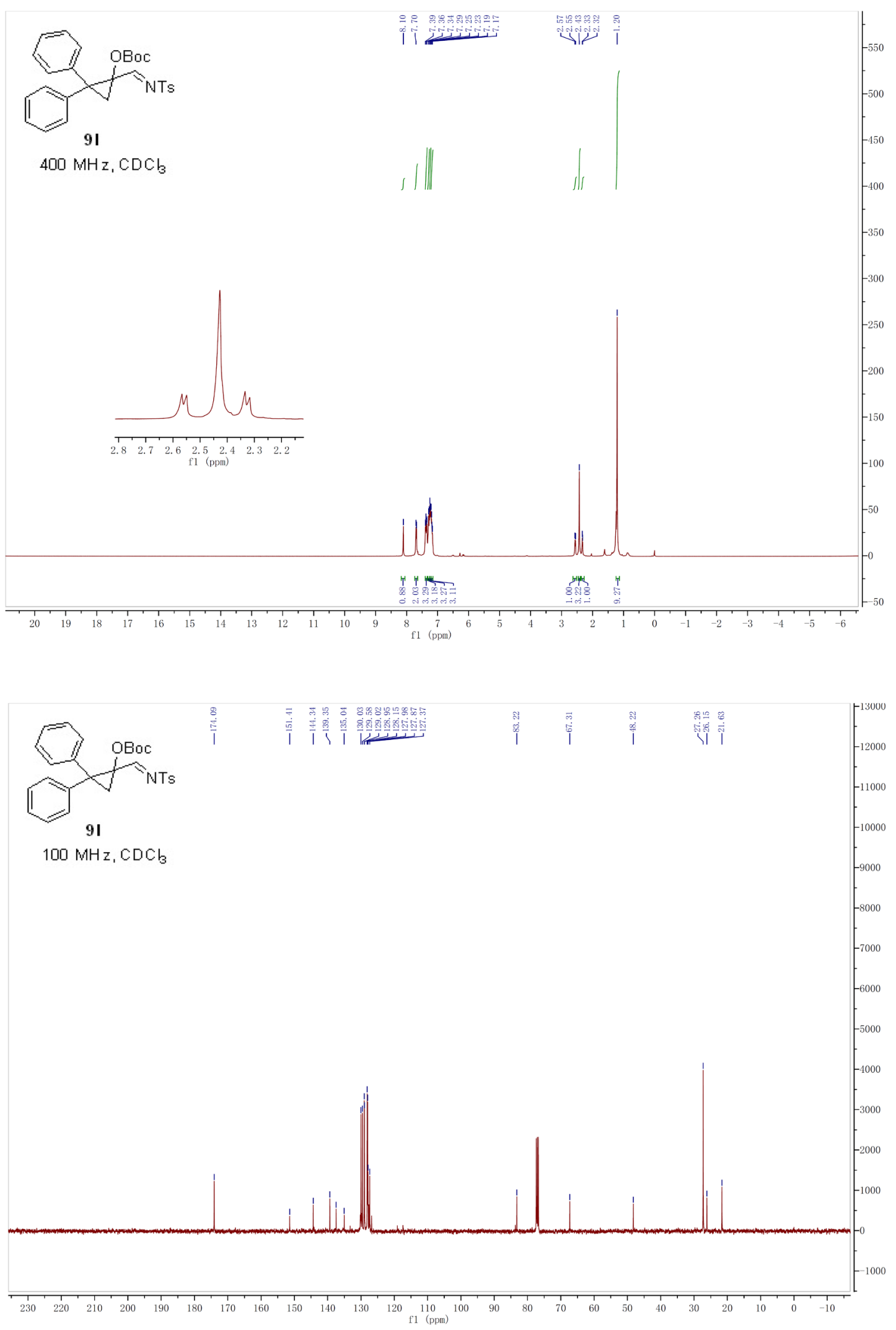

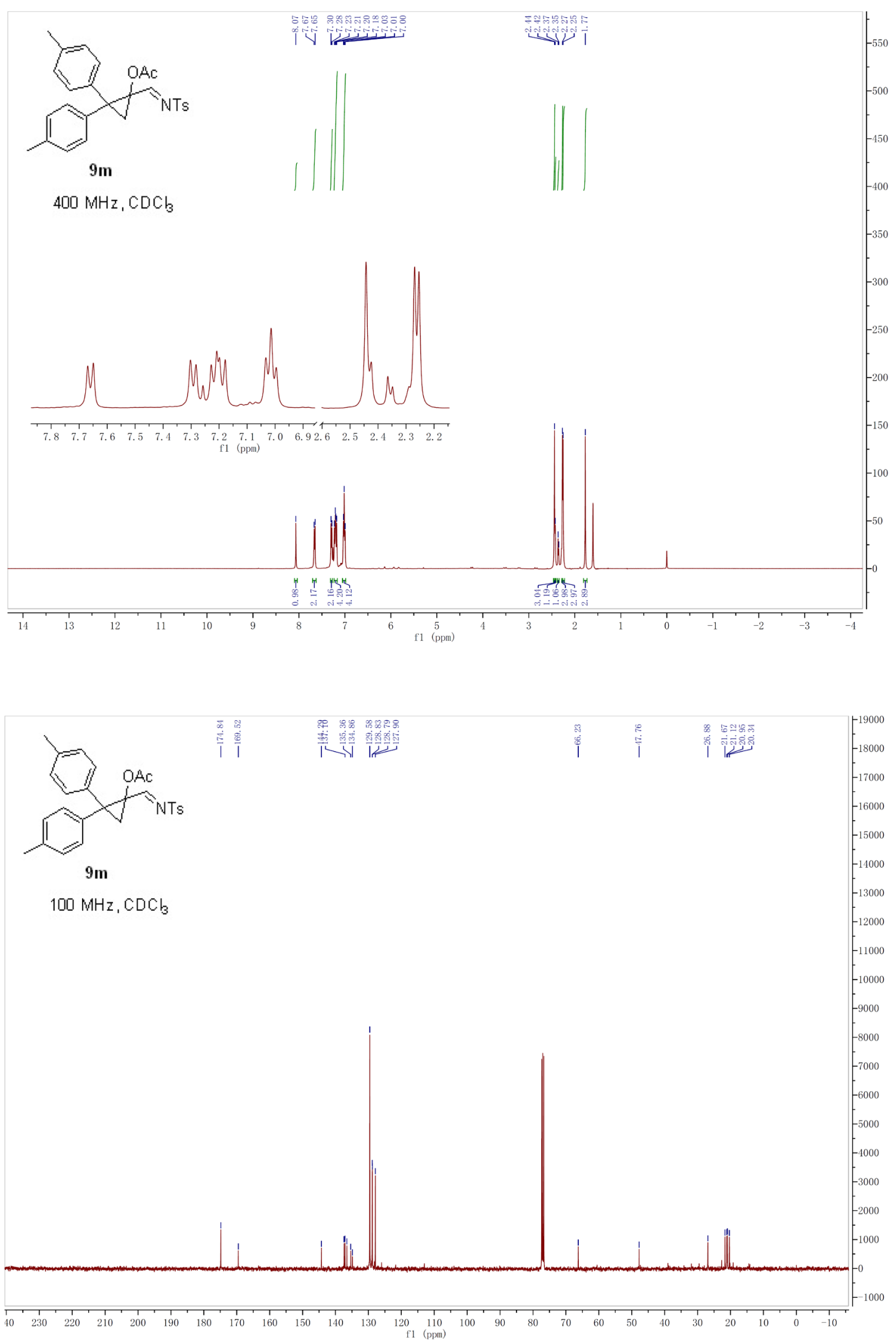

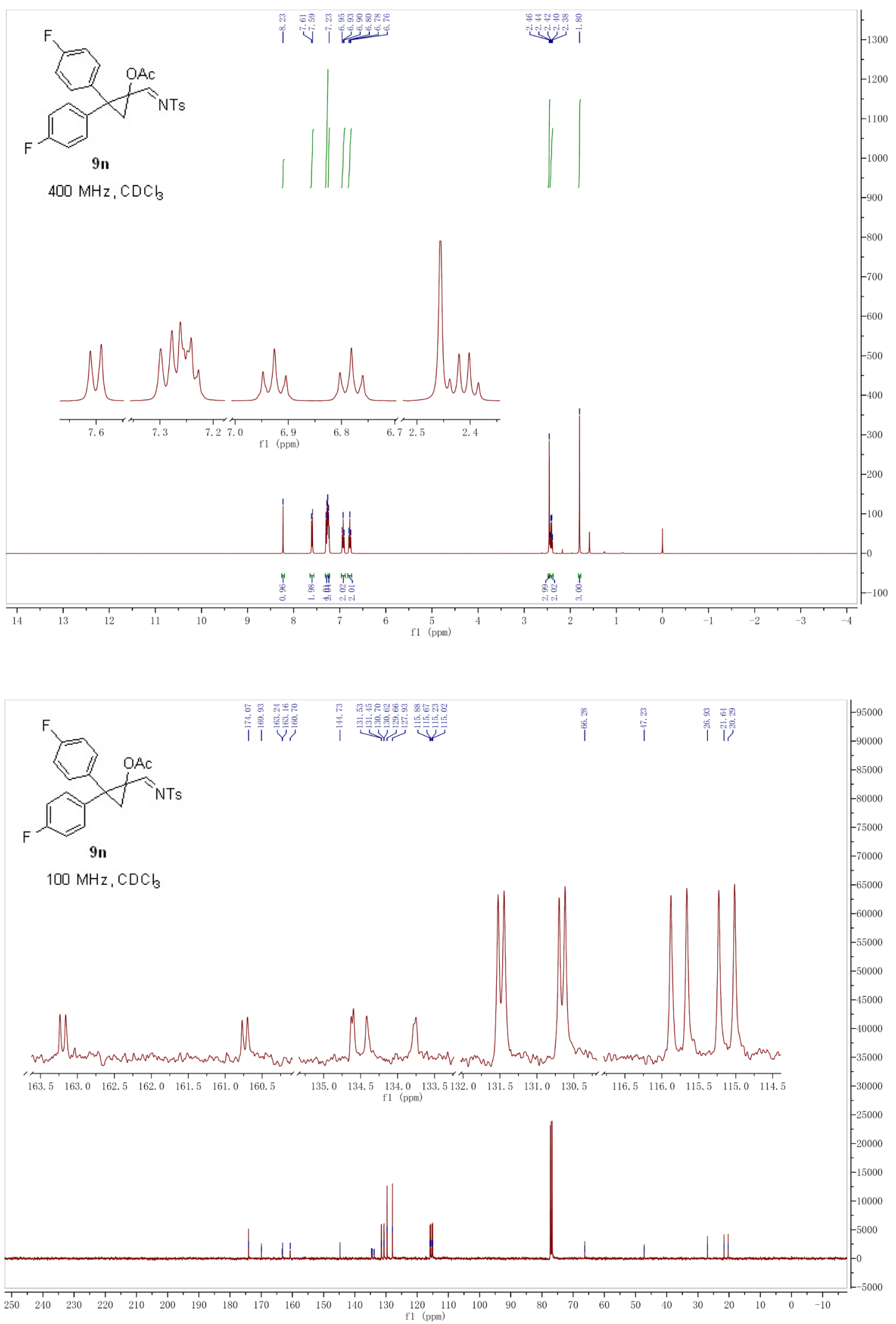

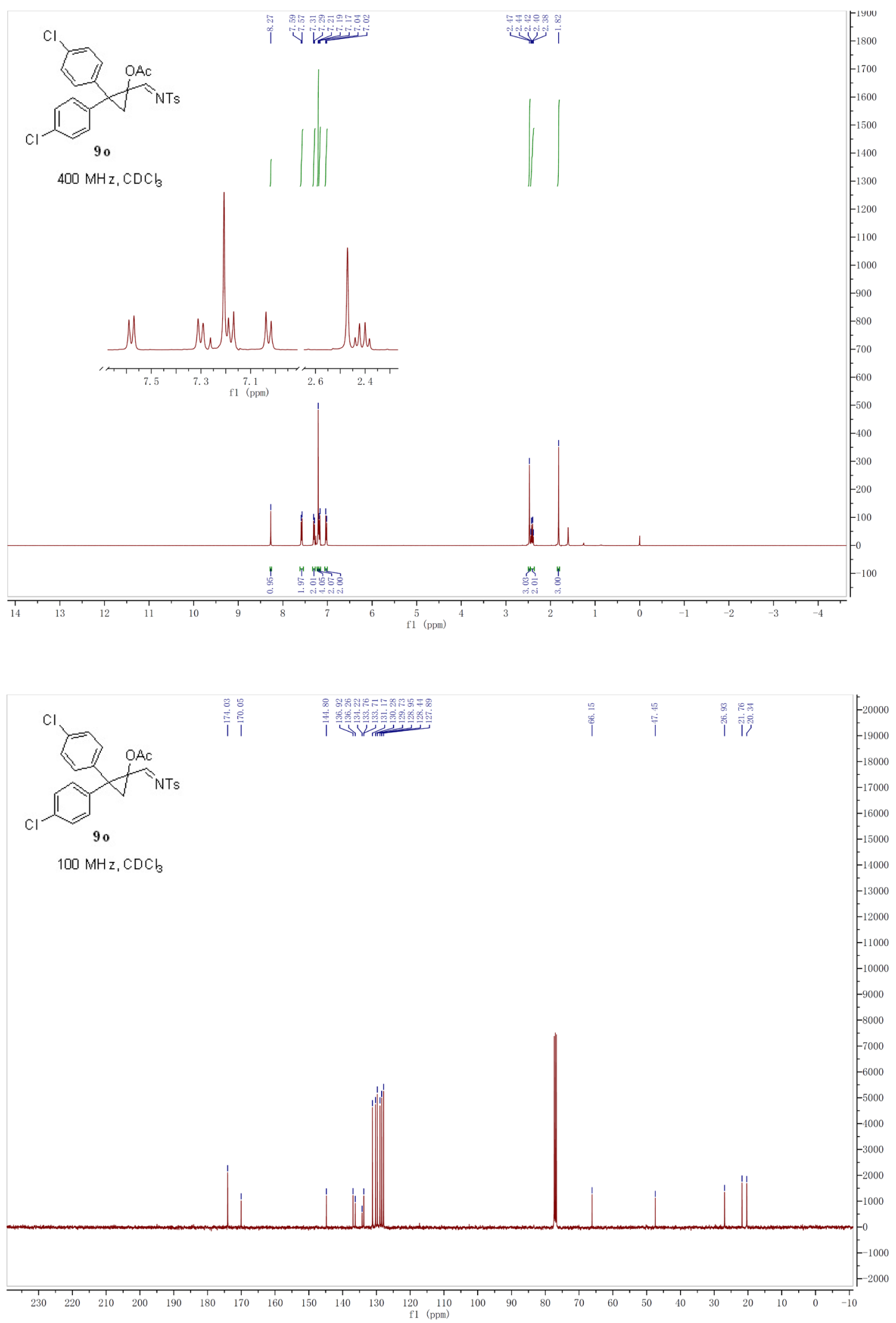

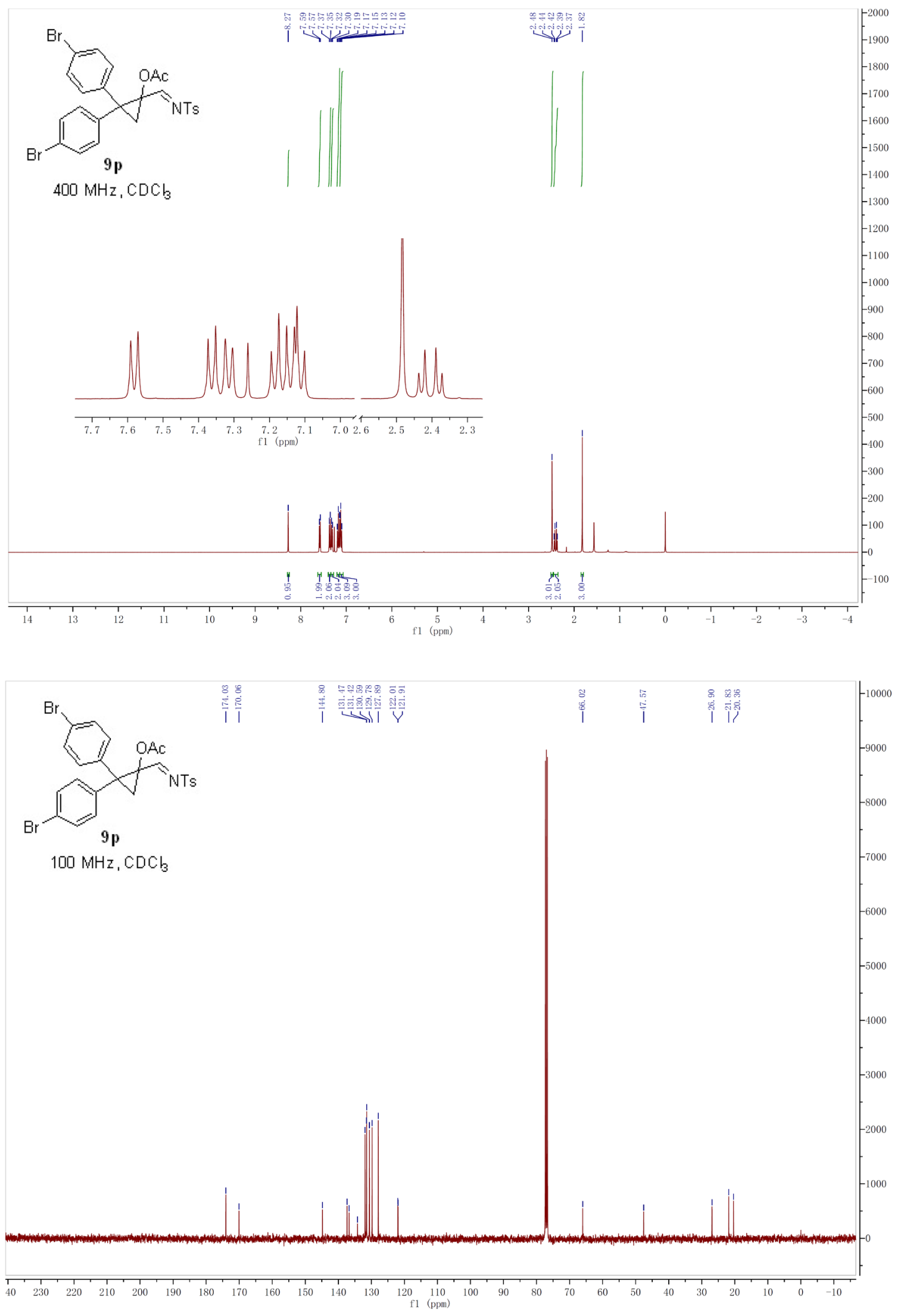


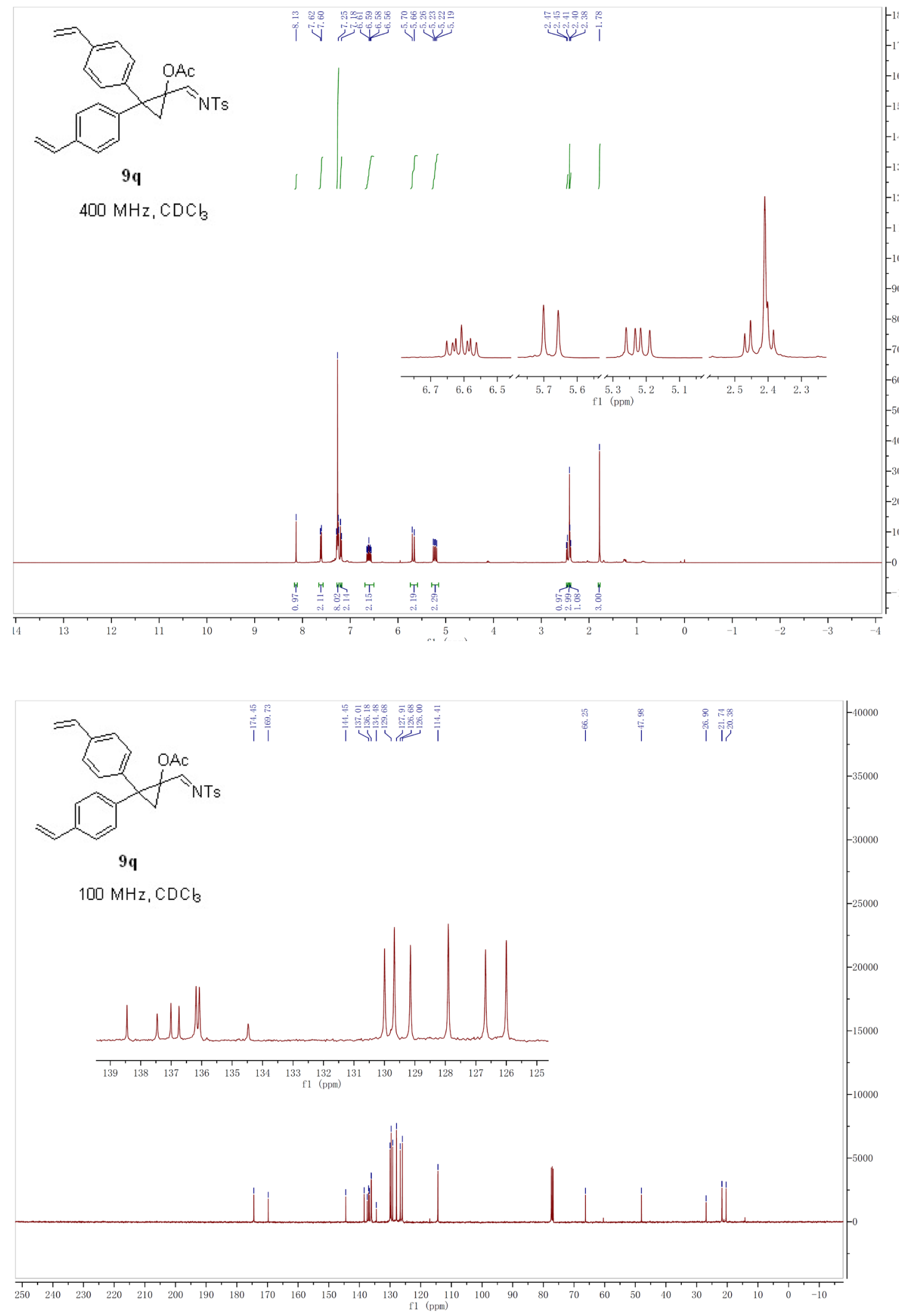



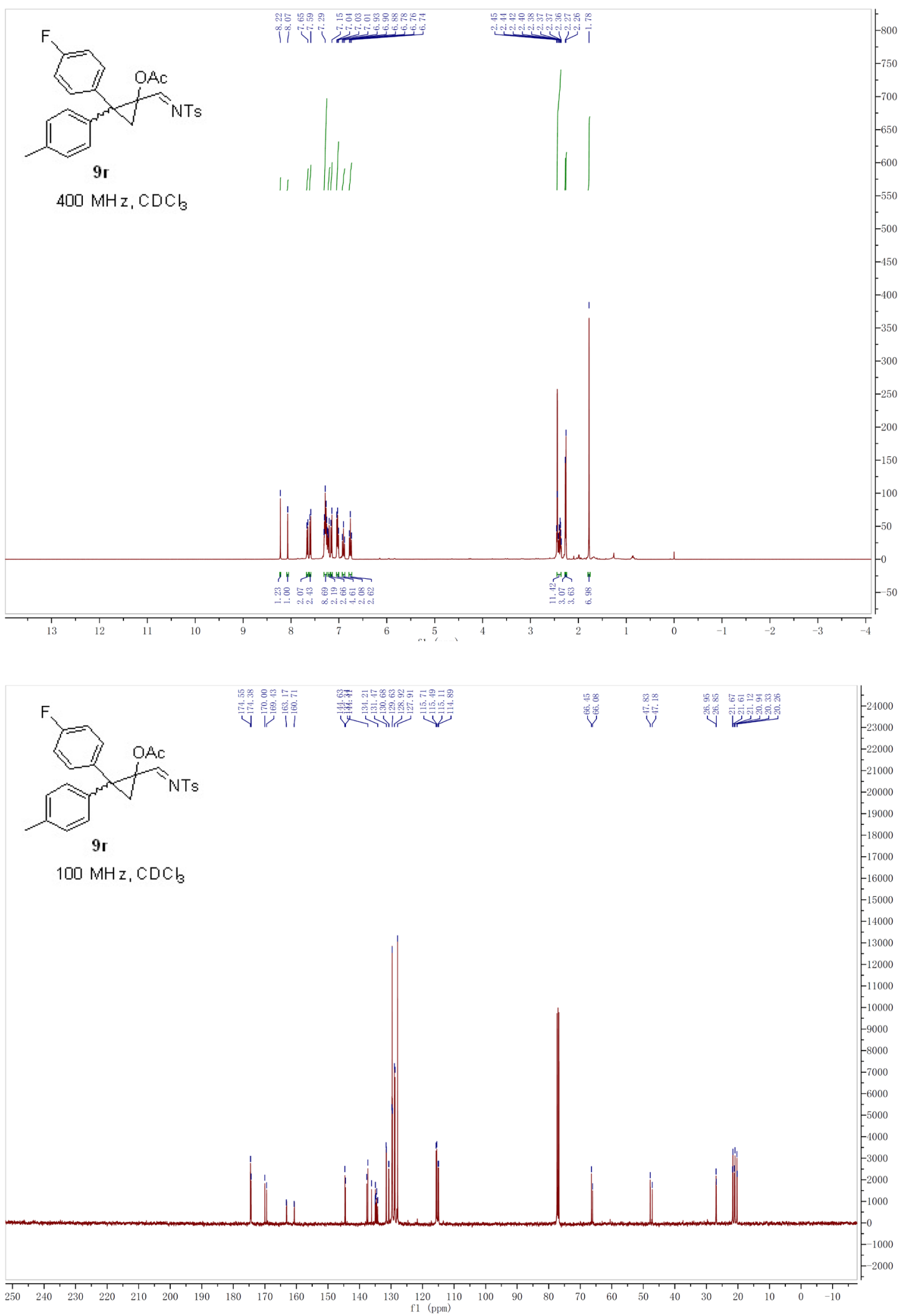


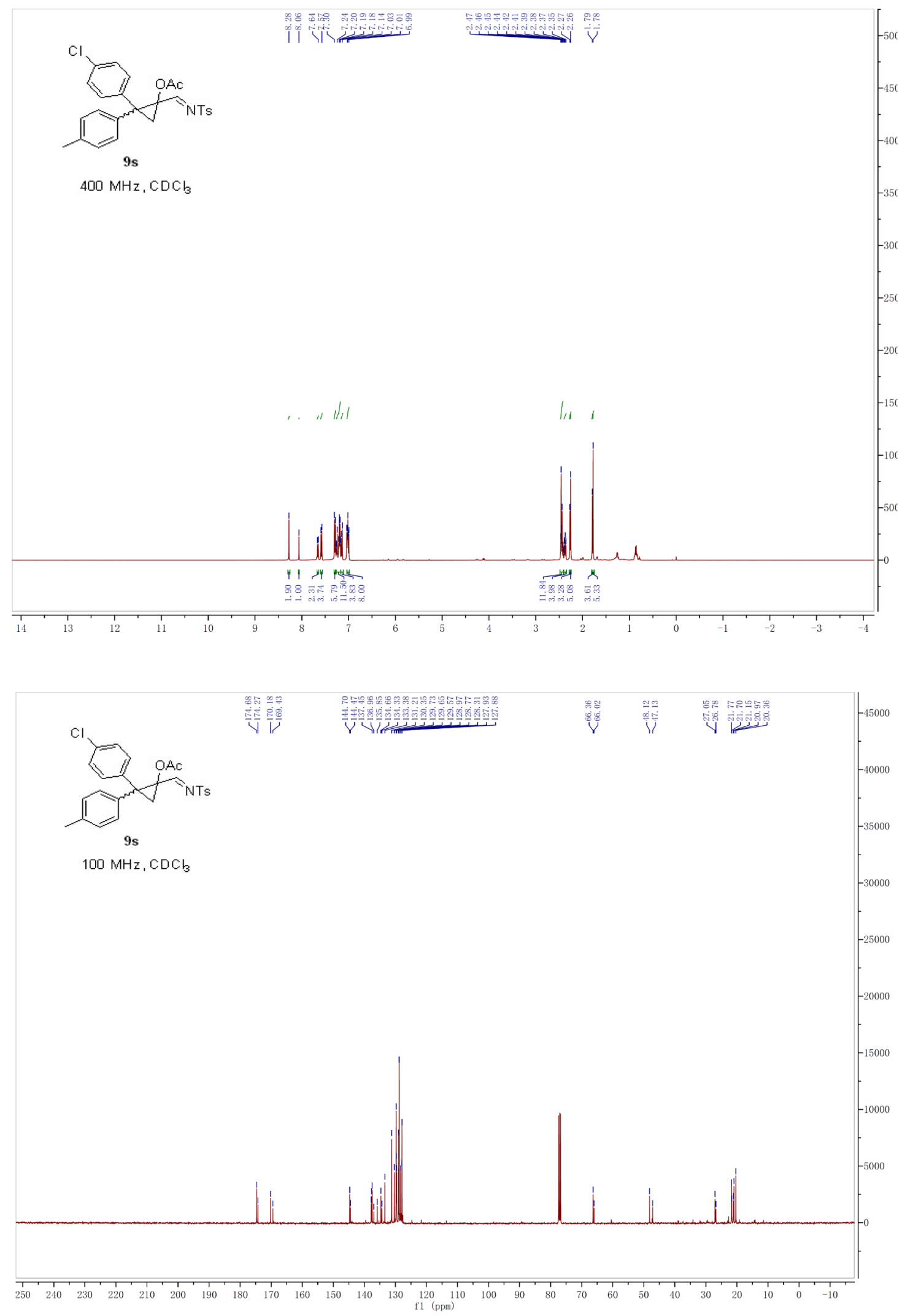



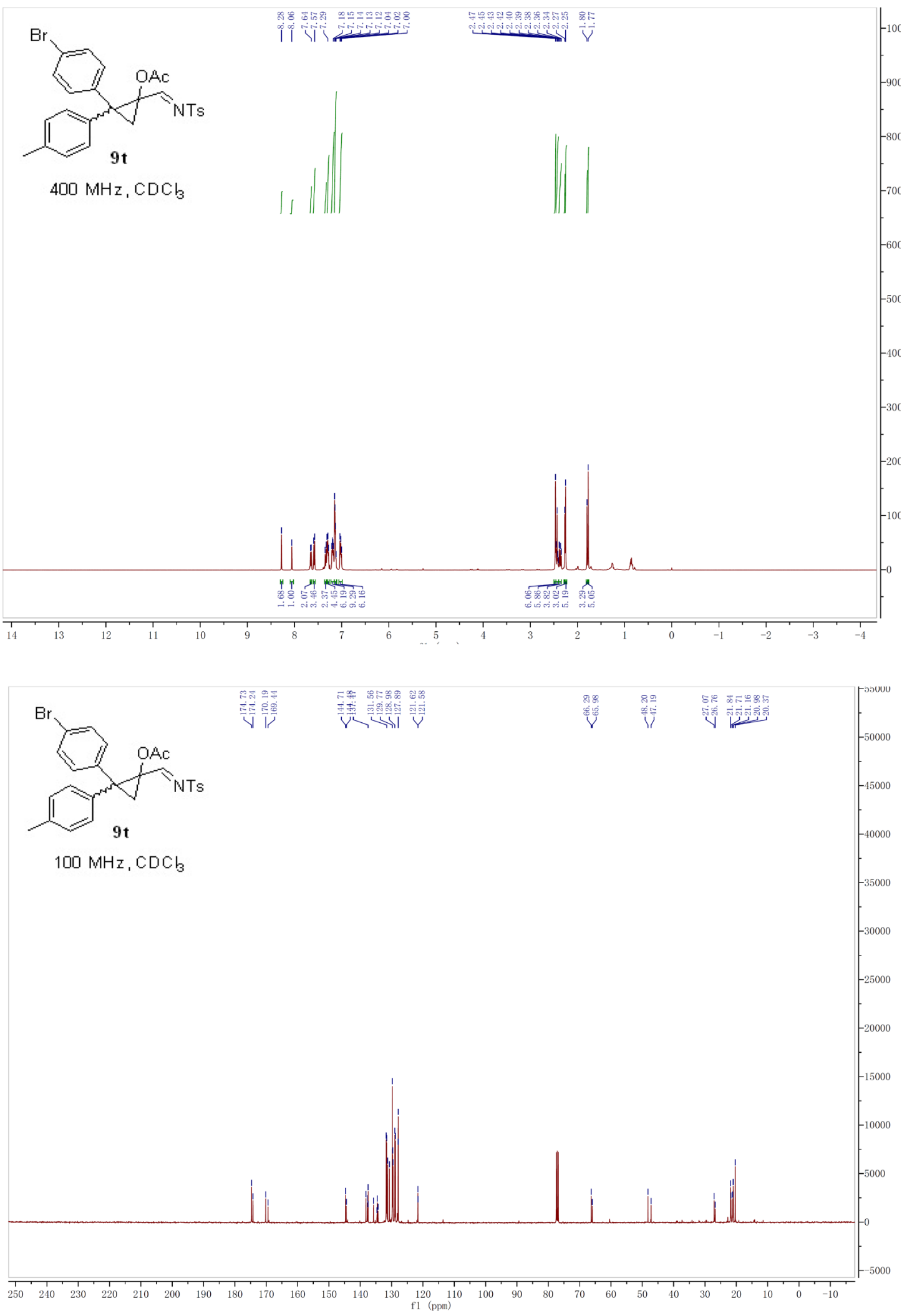

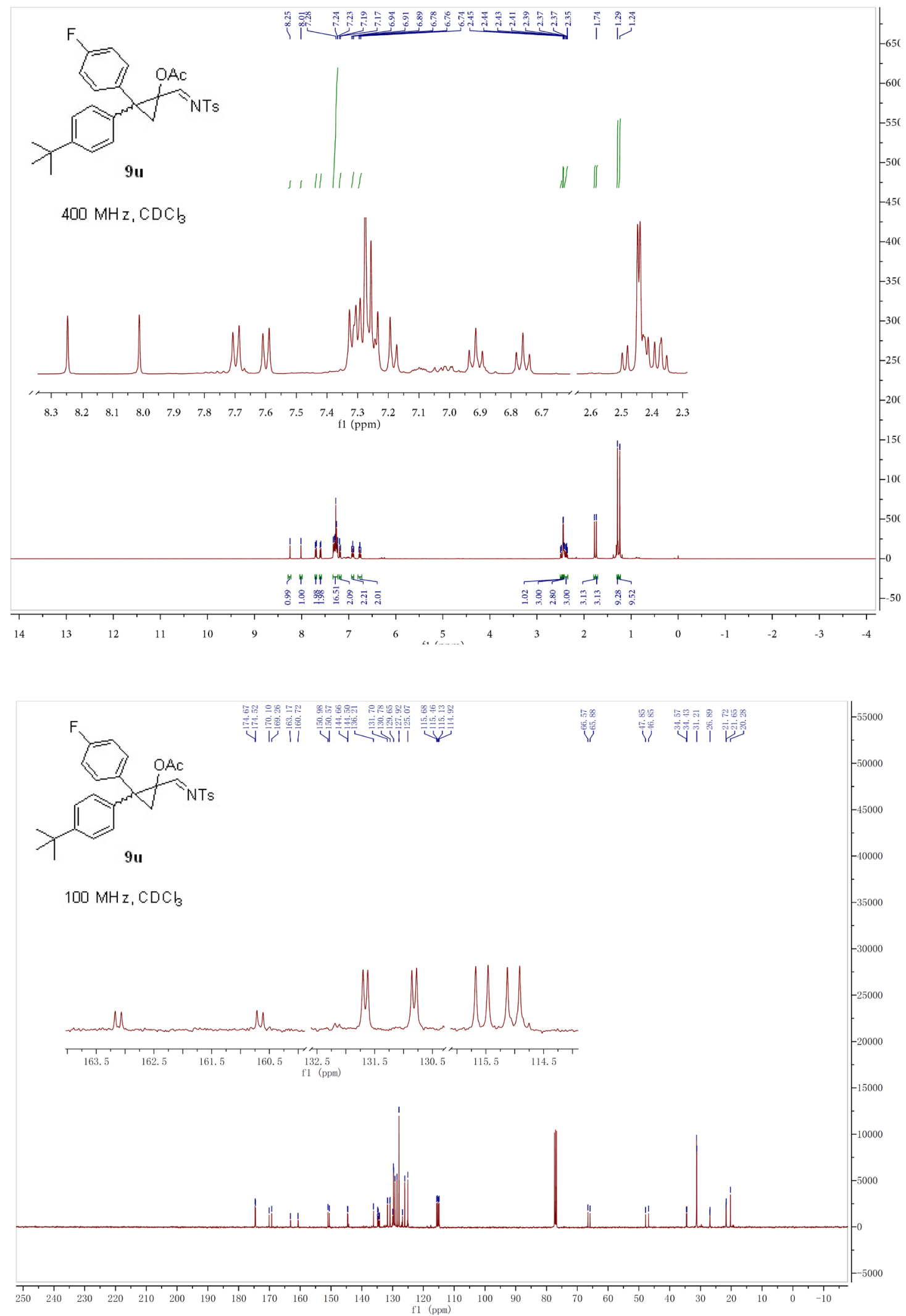

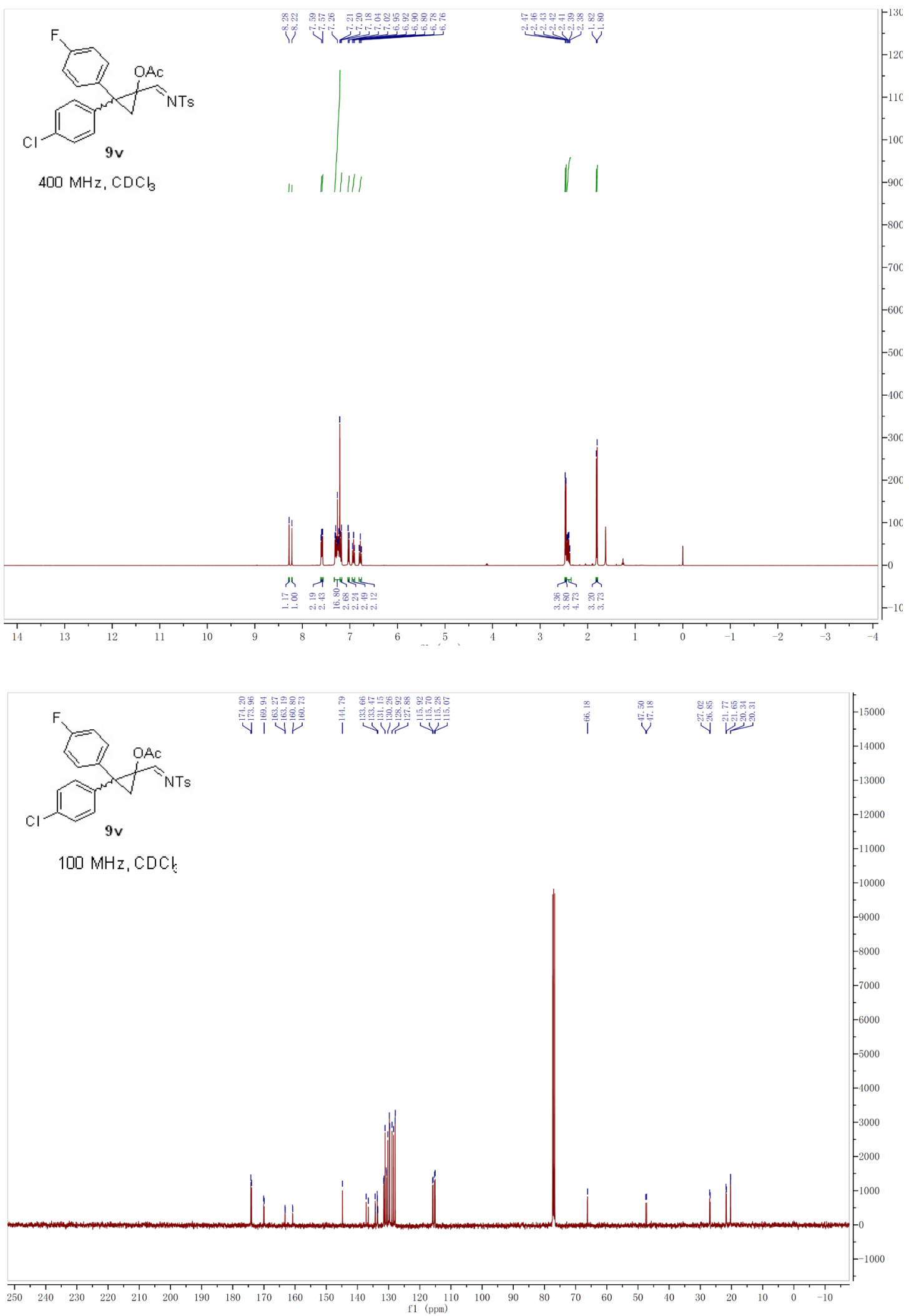

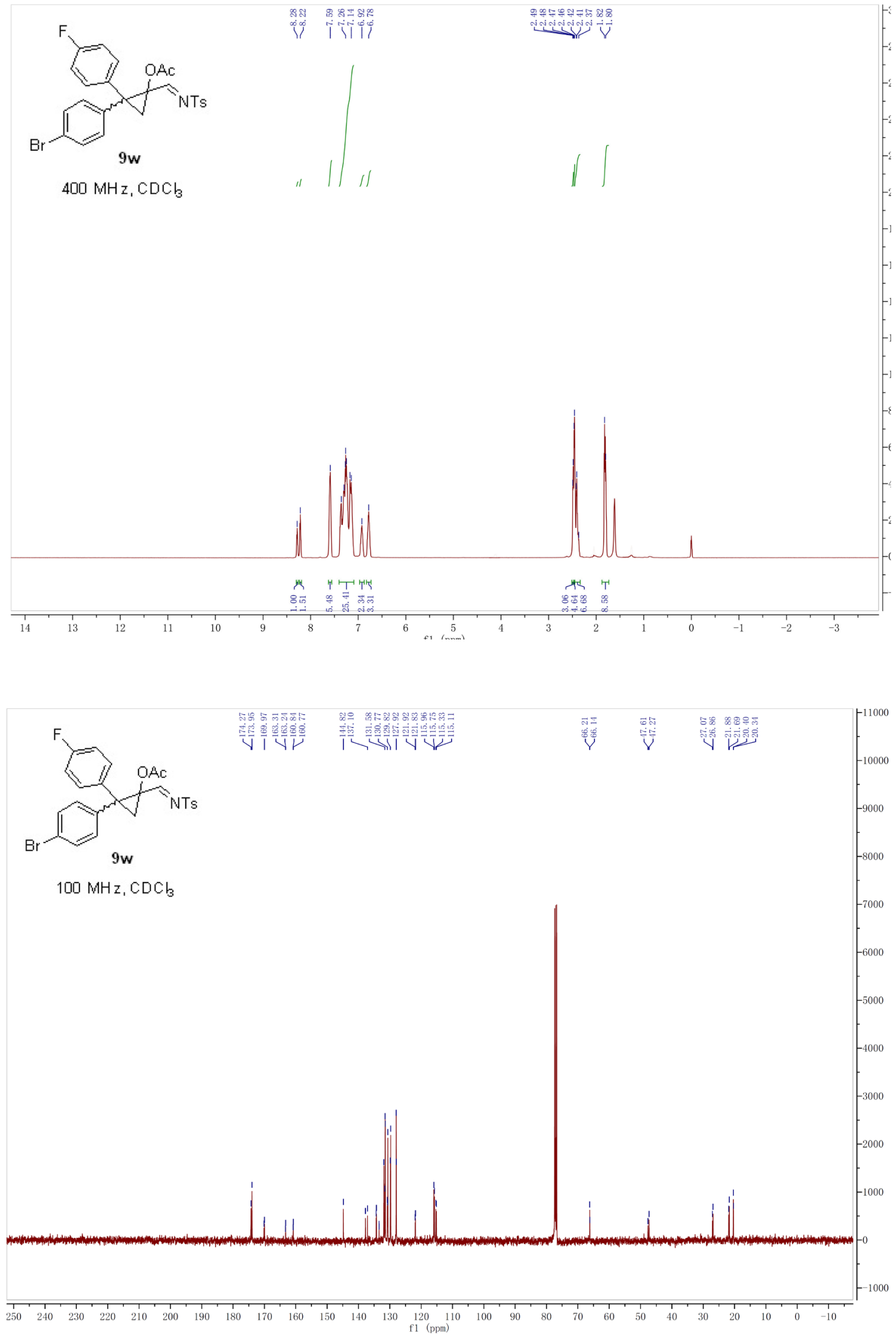

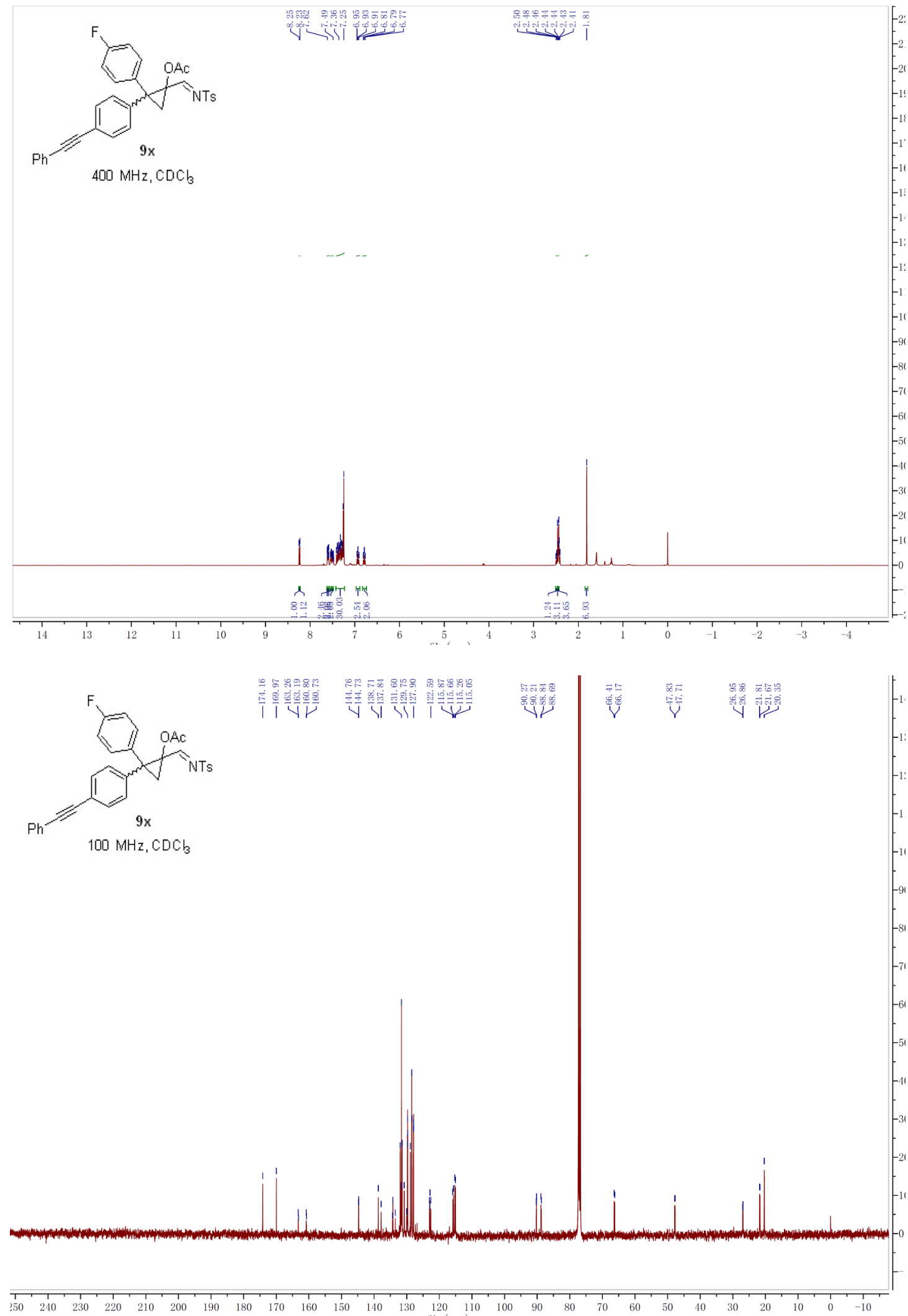

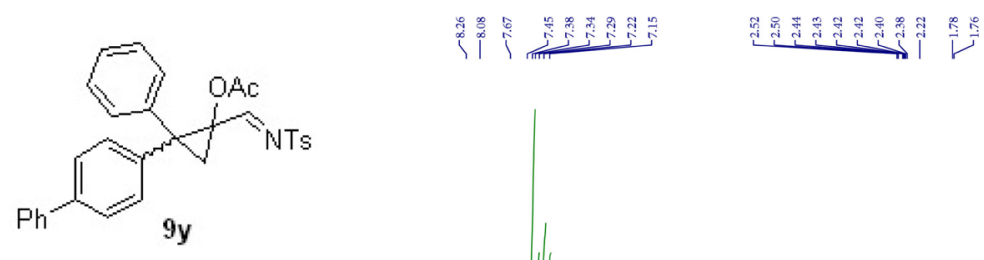

$400 \mathrm{MHz}_{1} \mathrm{CDCl}_{3}$
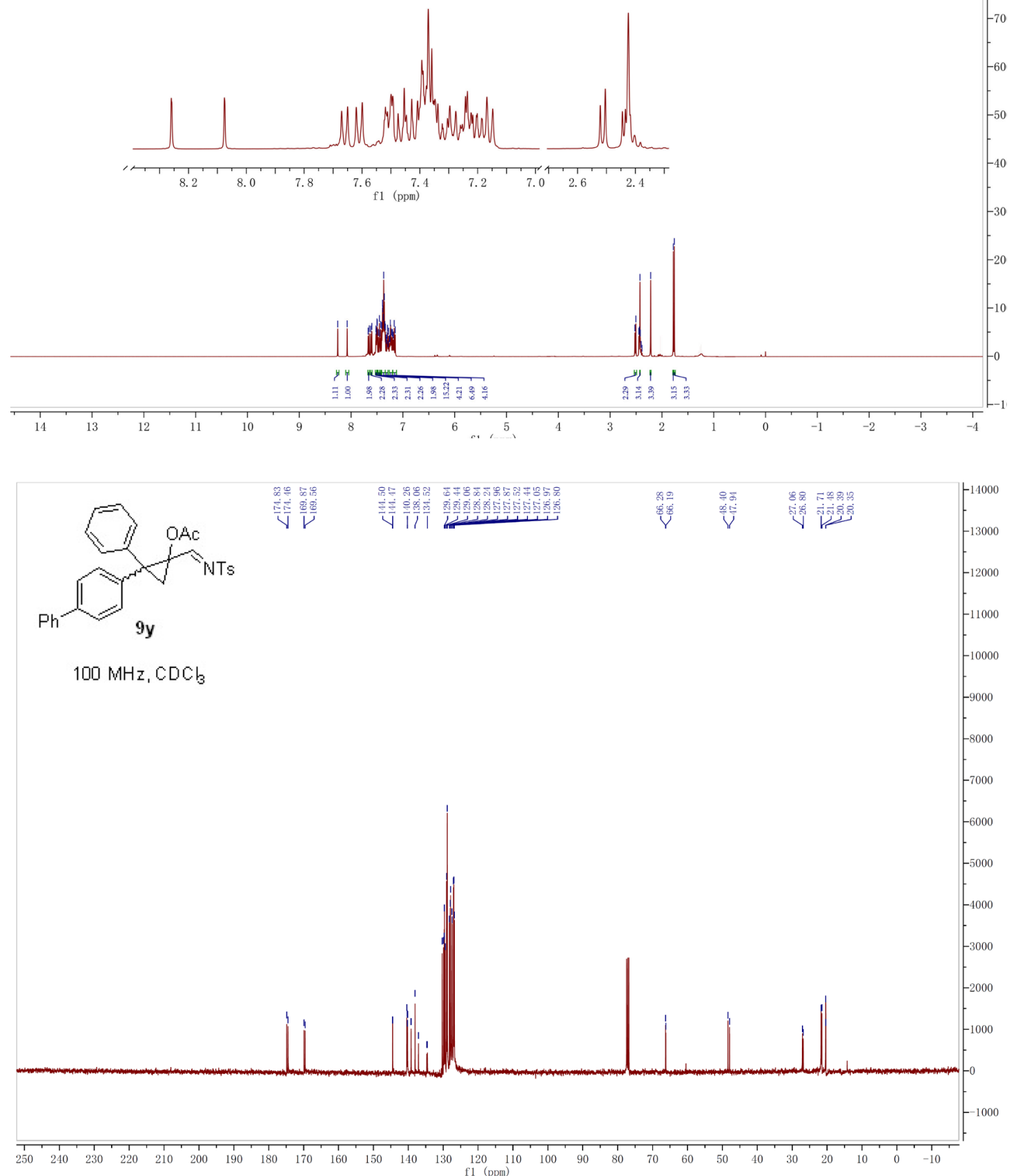


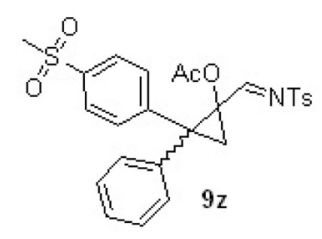

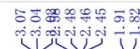

$400 \mathrm{MHz}_{1} \mathrm{CDCb}$

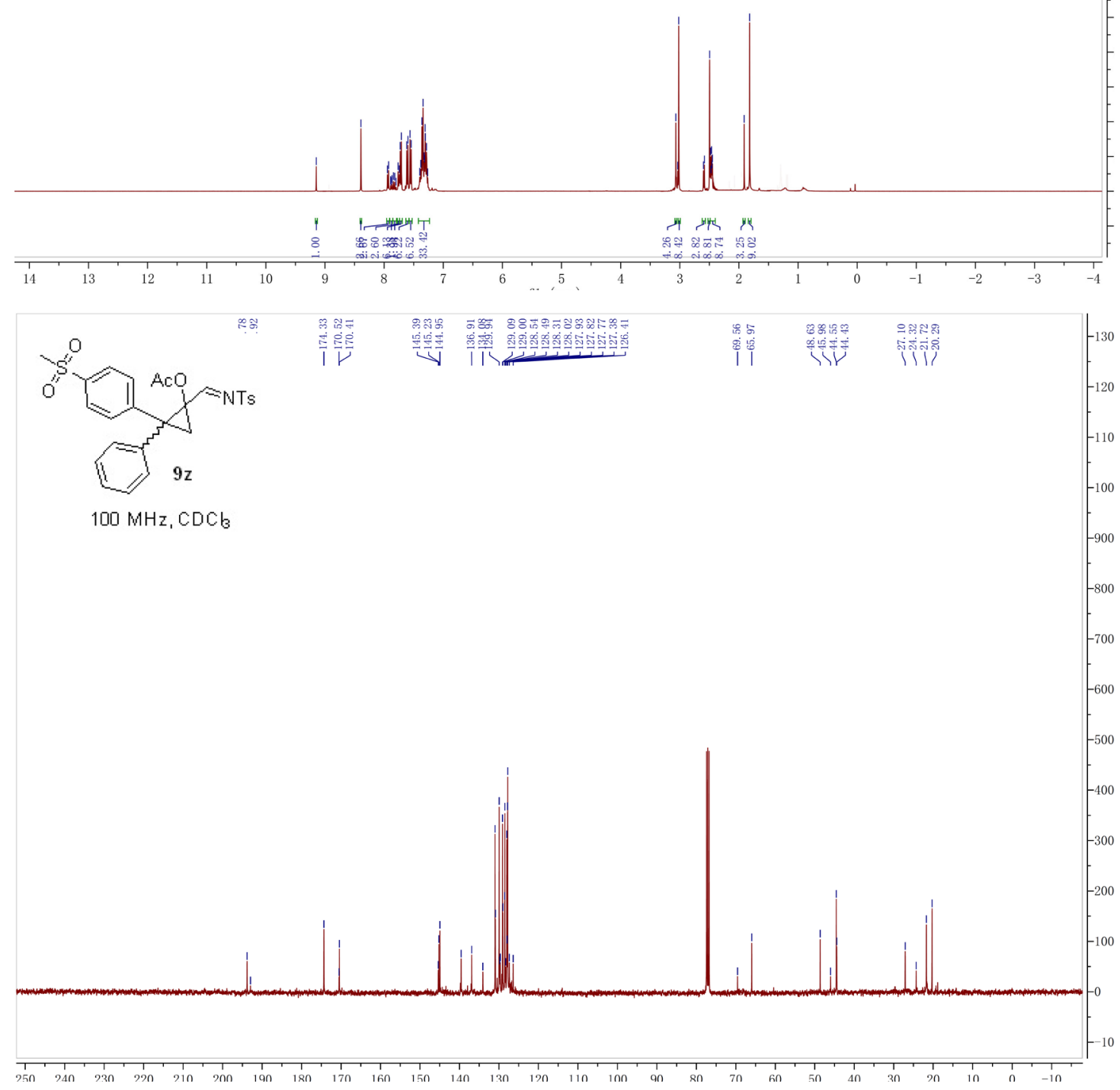




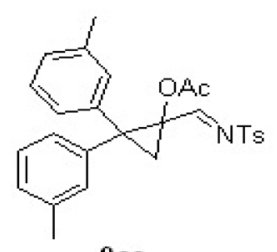

9 aa

$400 \mathrm{MHz}, \mathrm{CDCl}_{3}$

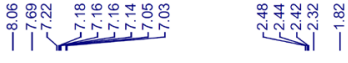

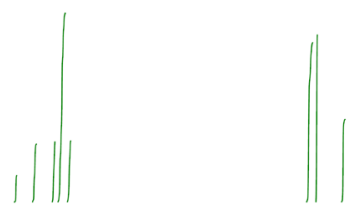

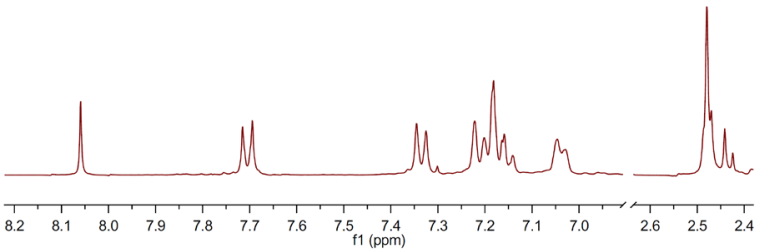
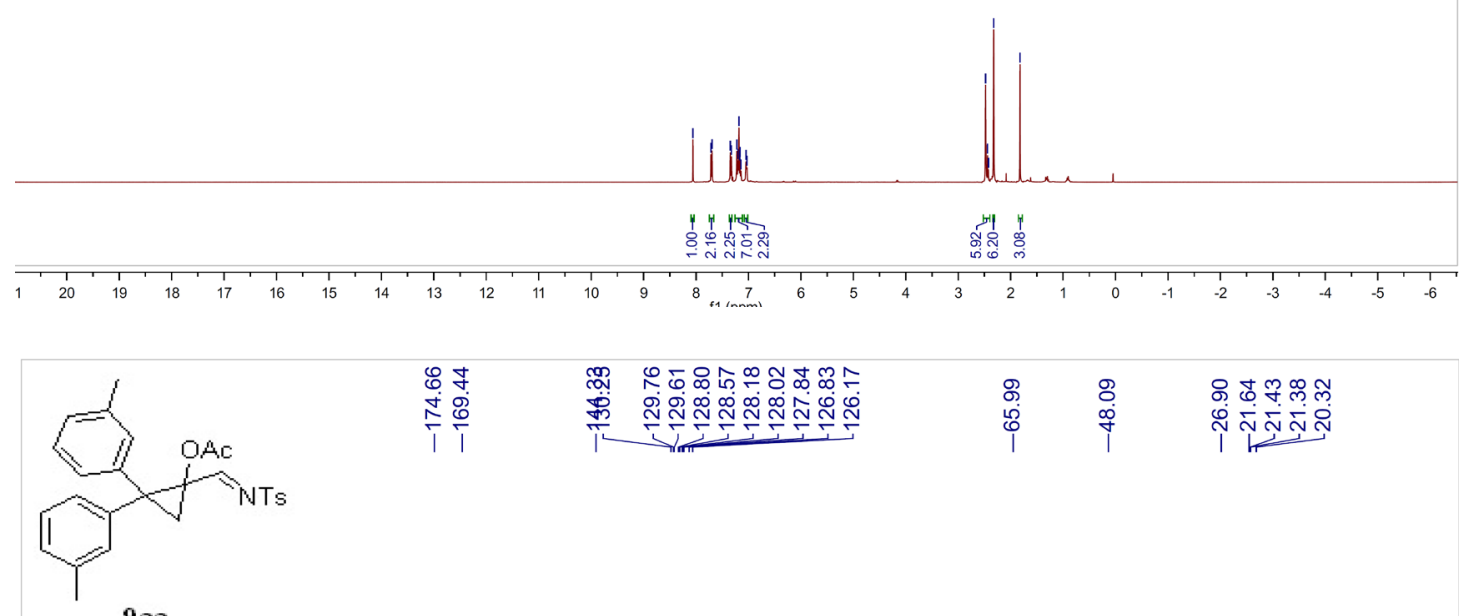

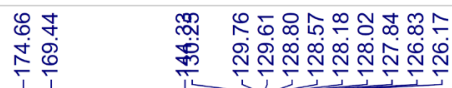

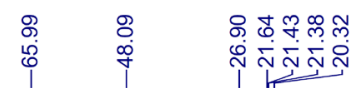

$100 \mathrm{MHz}, \mathrm{CDCl}_{3}$

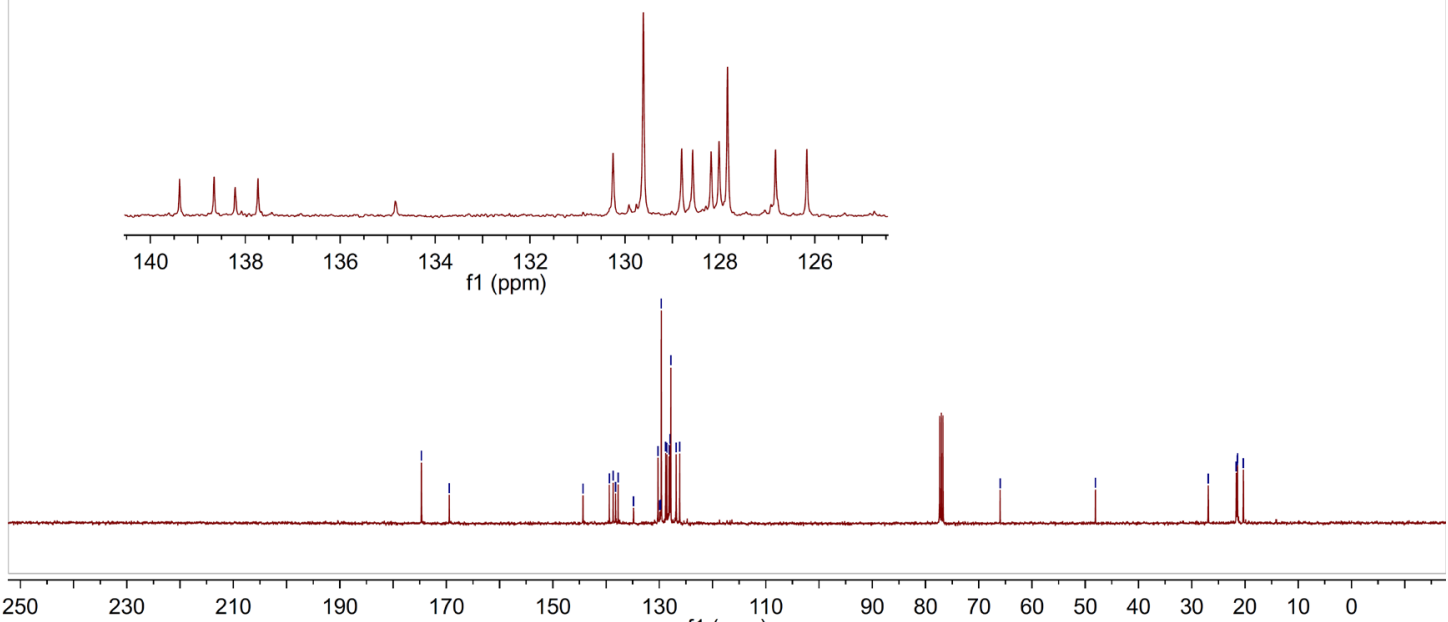




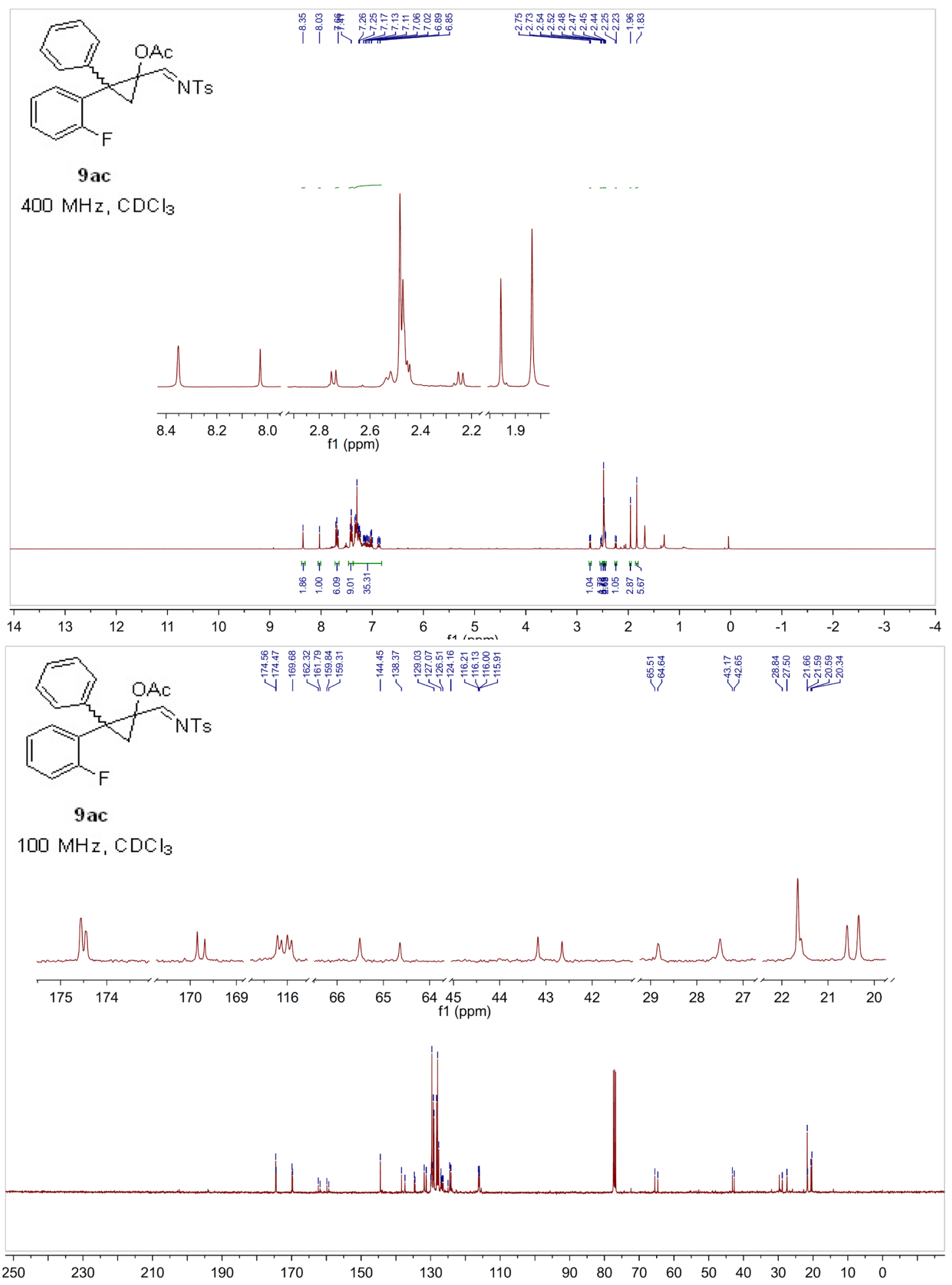



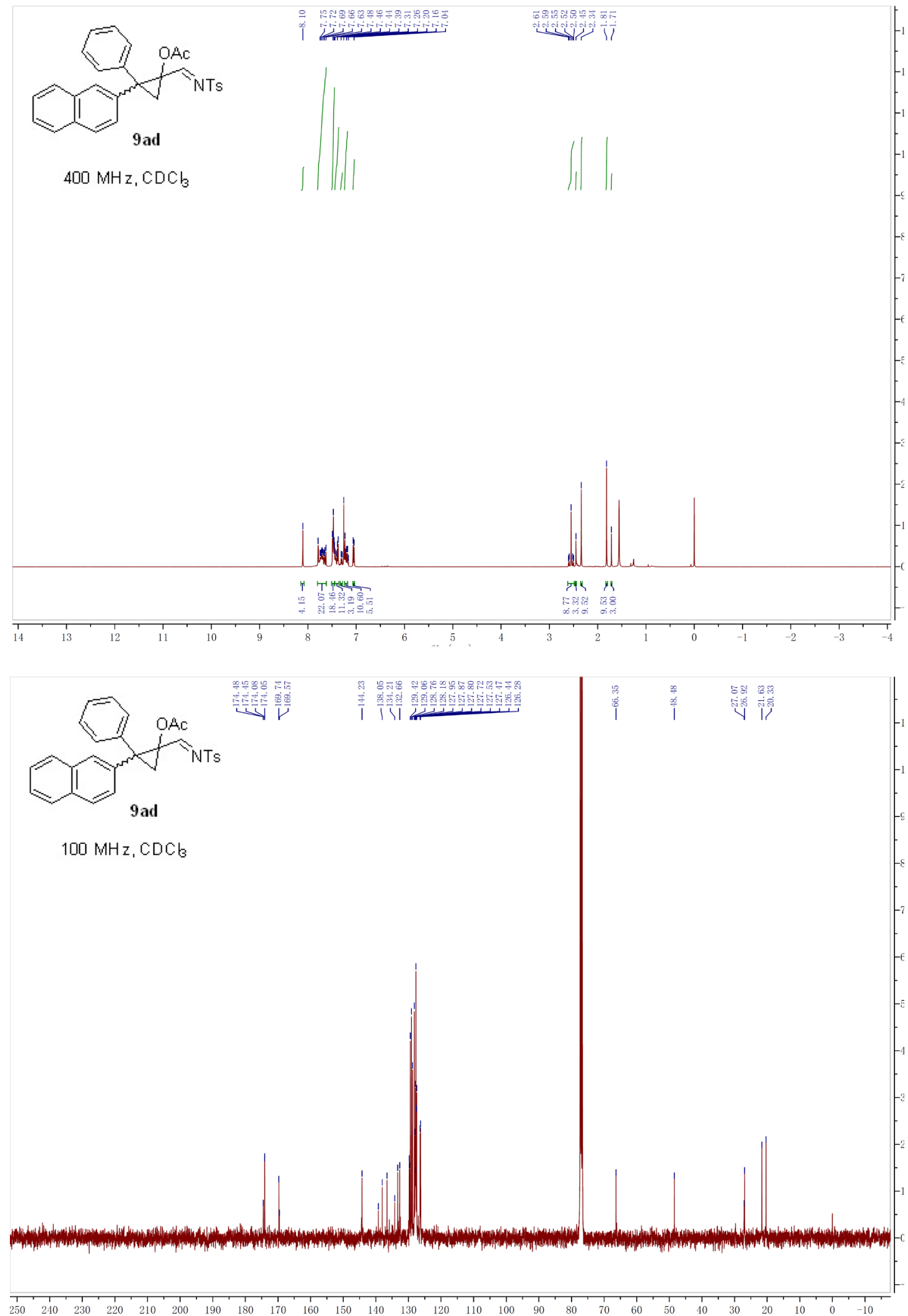


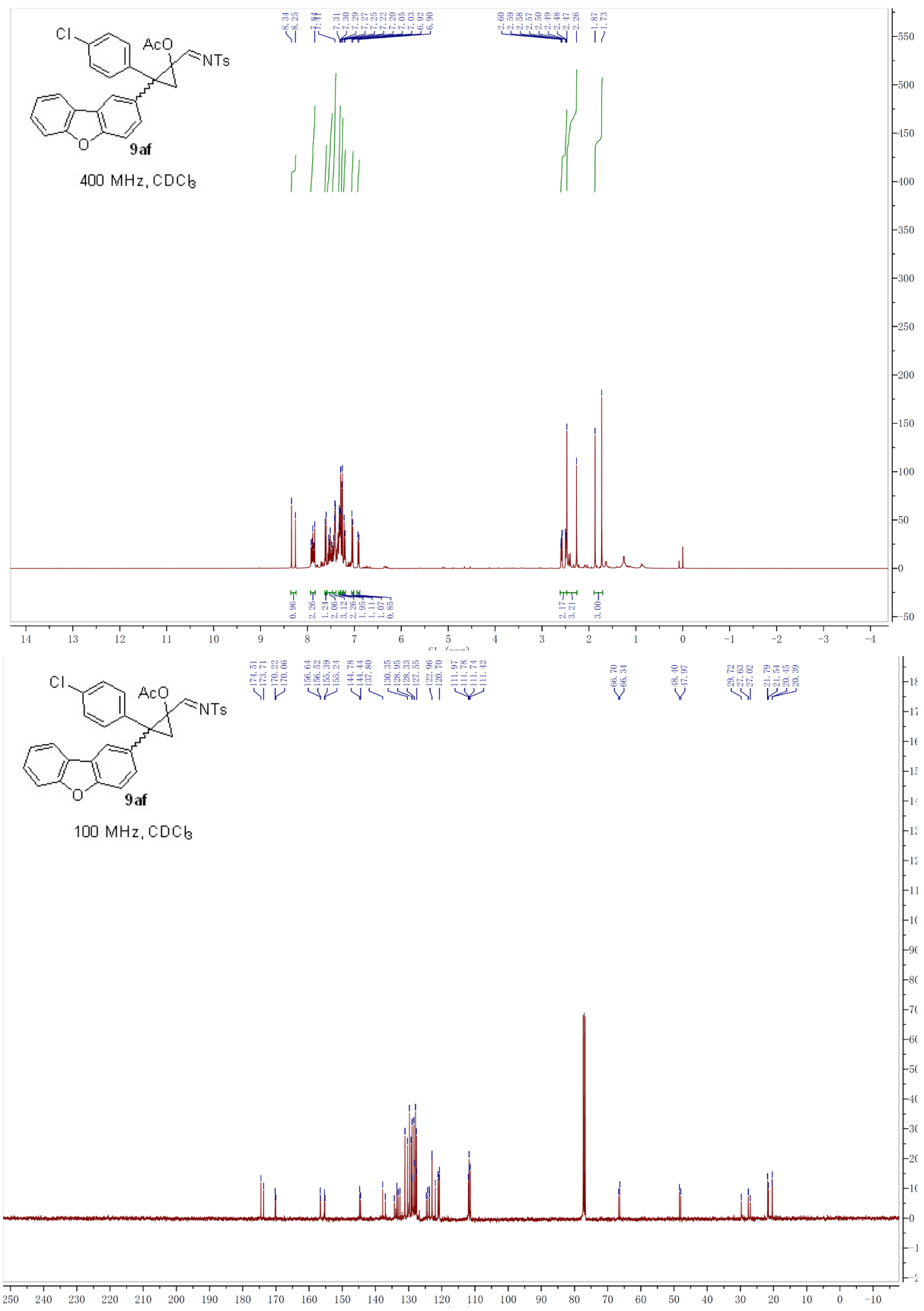




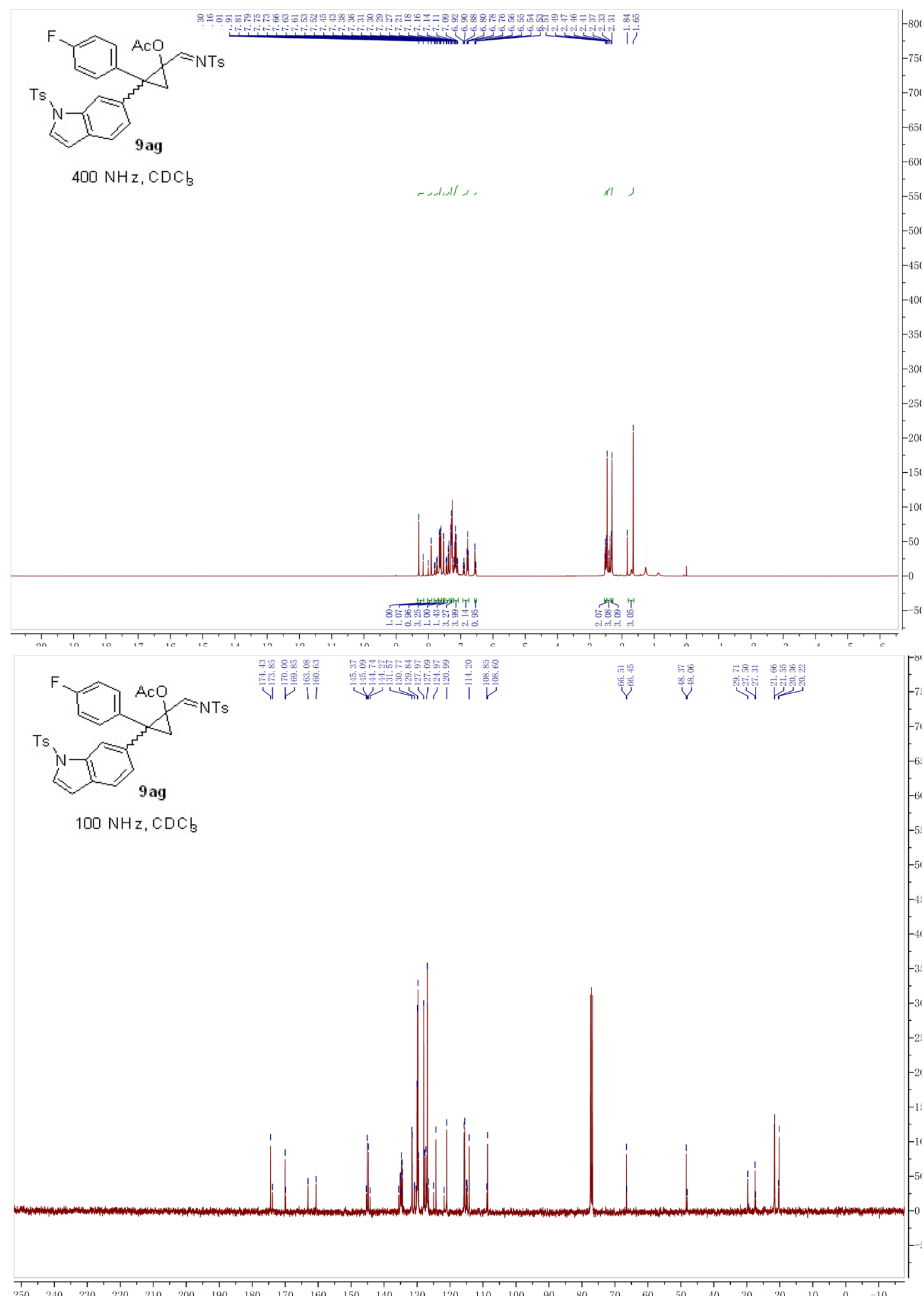

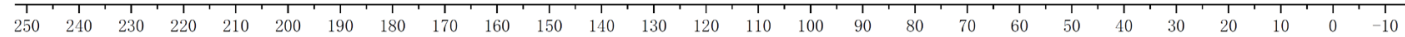




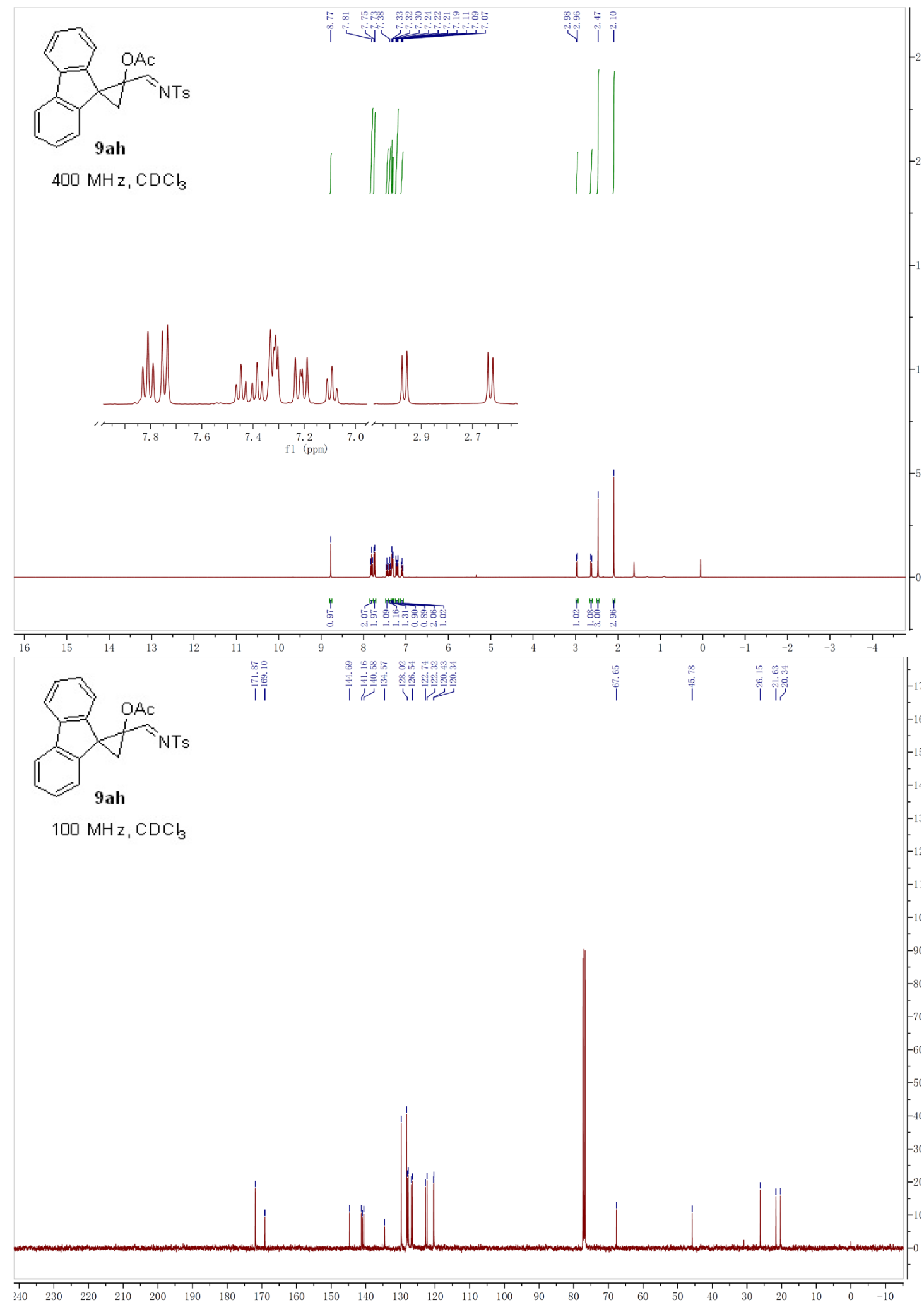



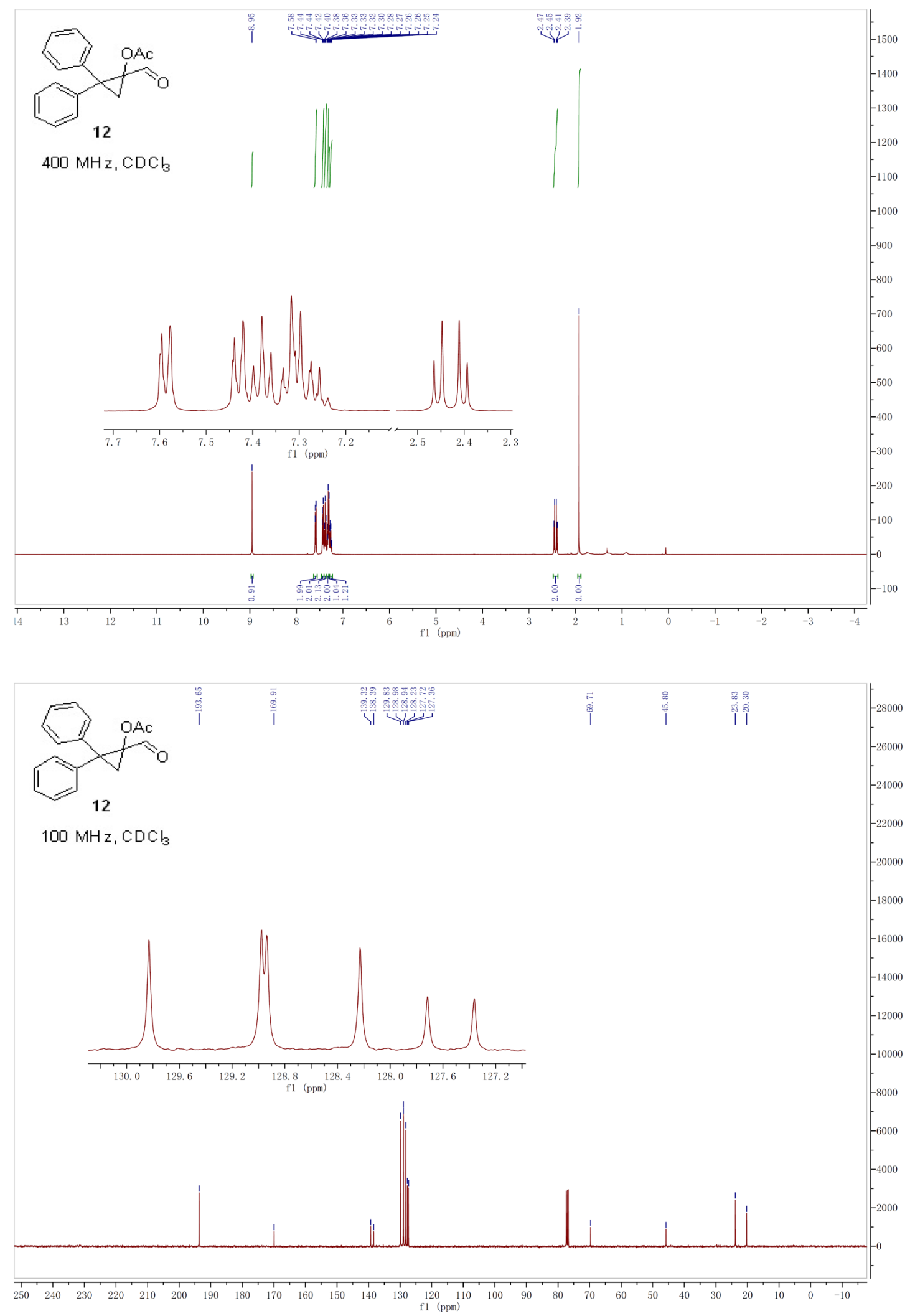

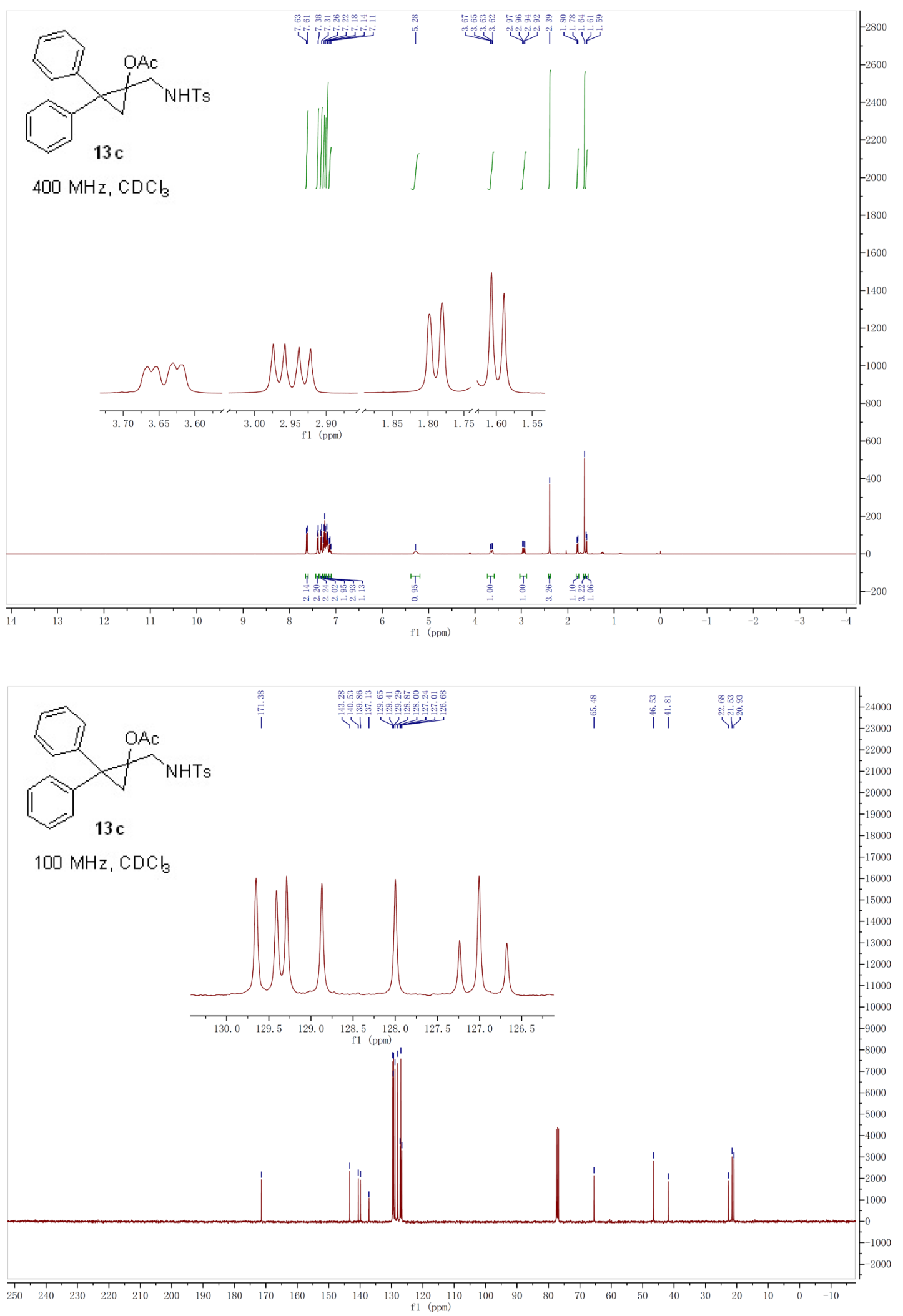

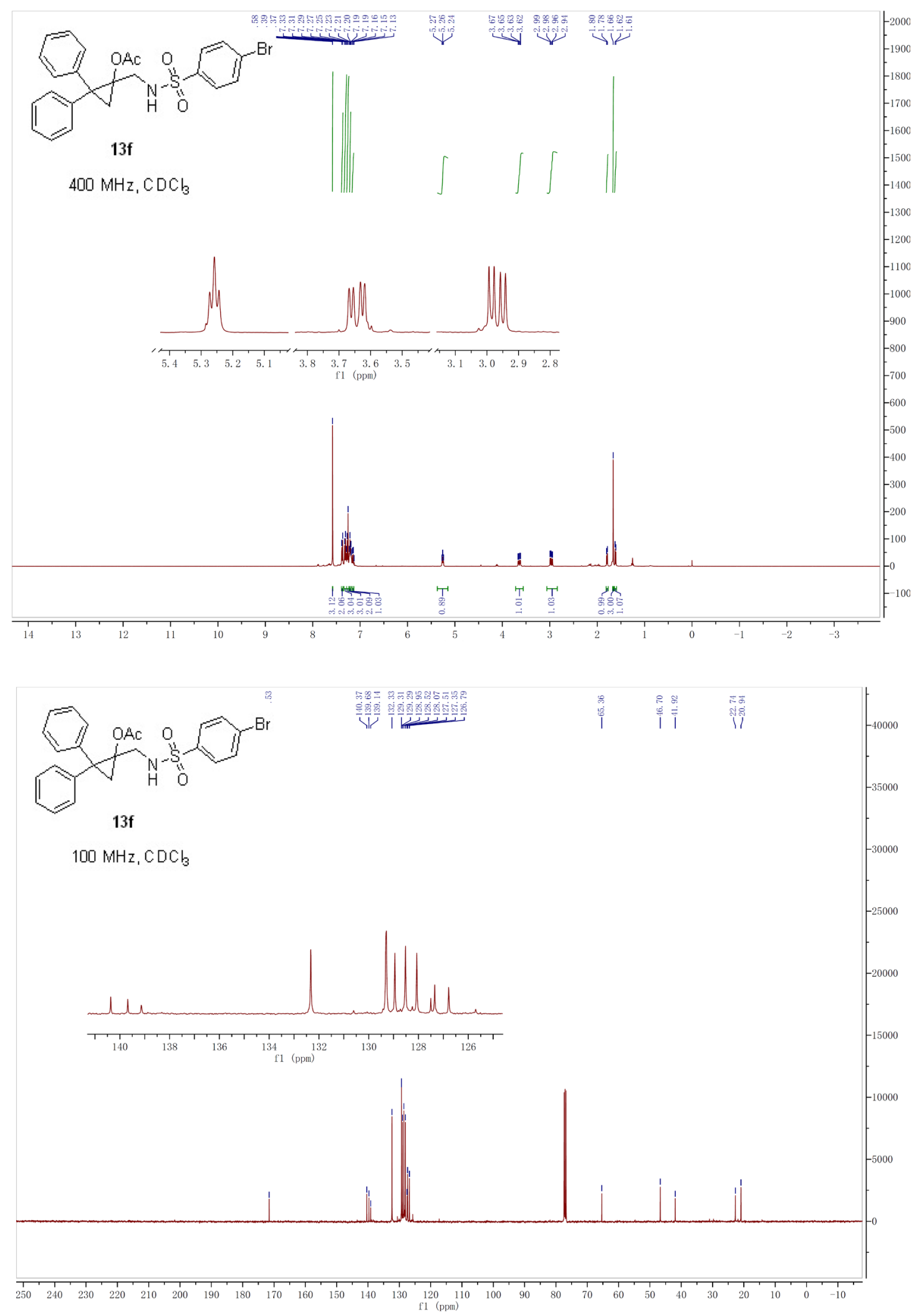


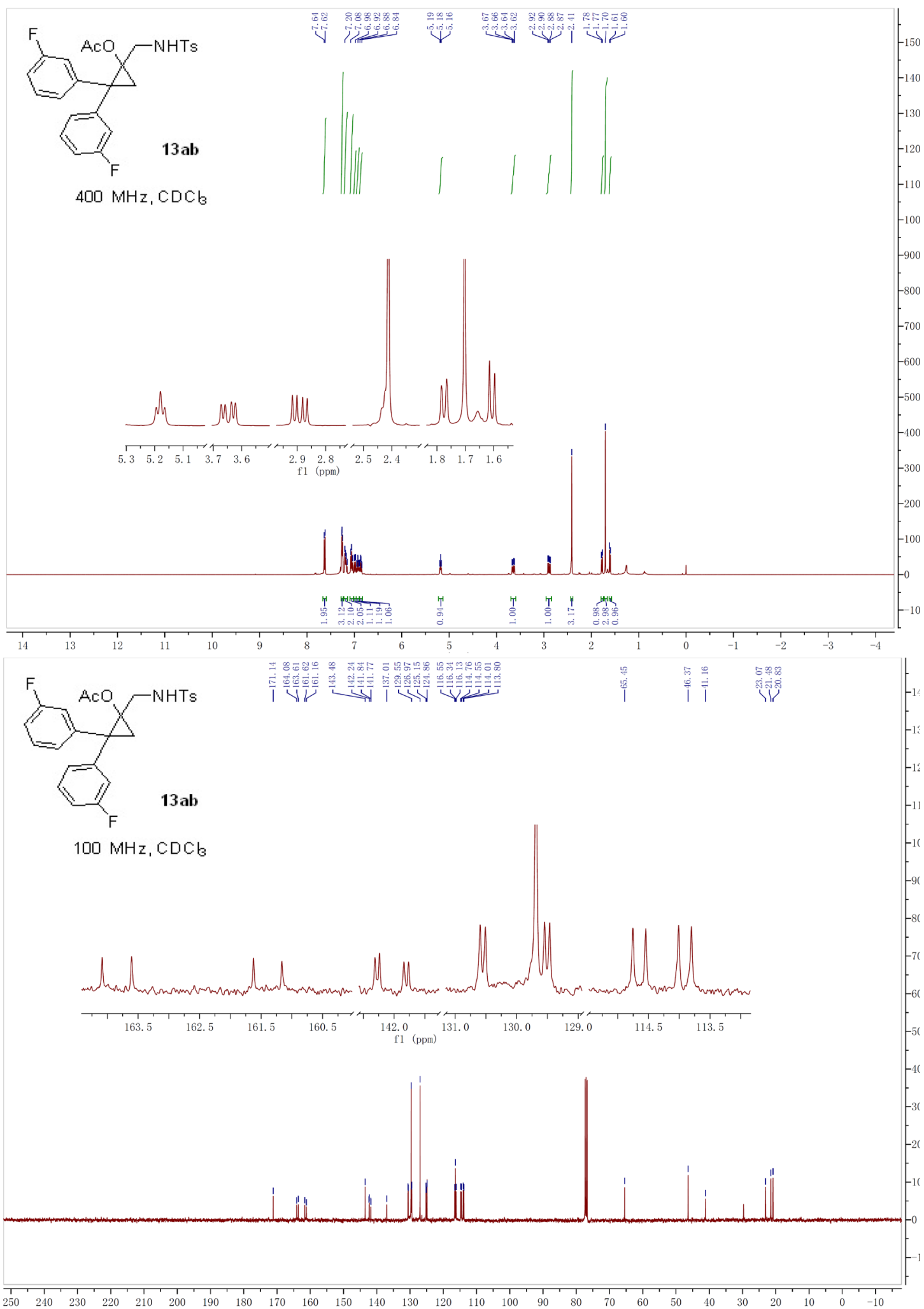




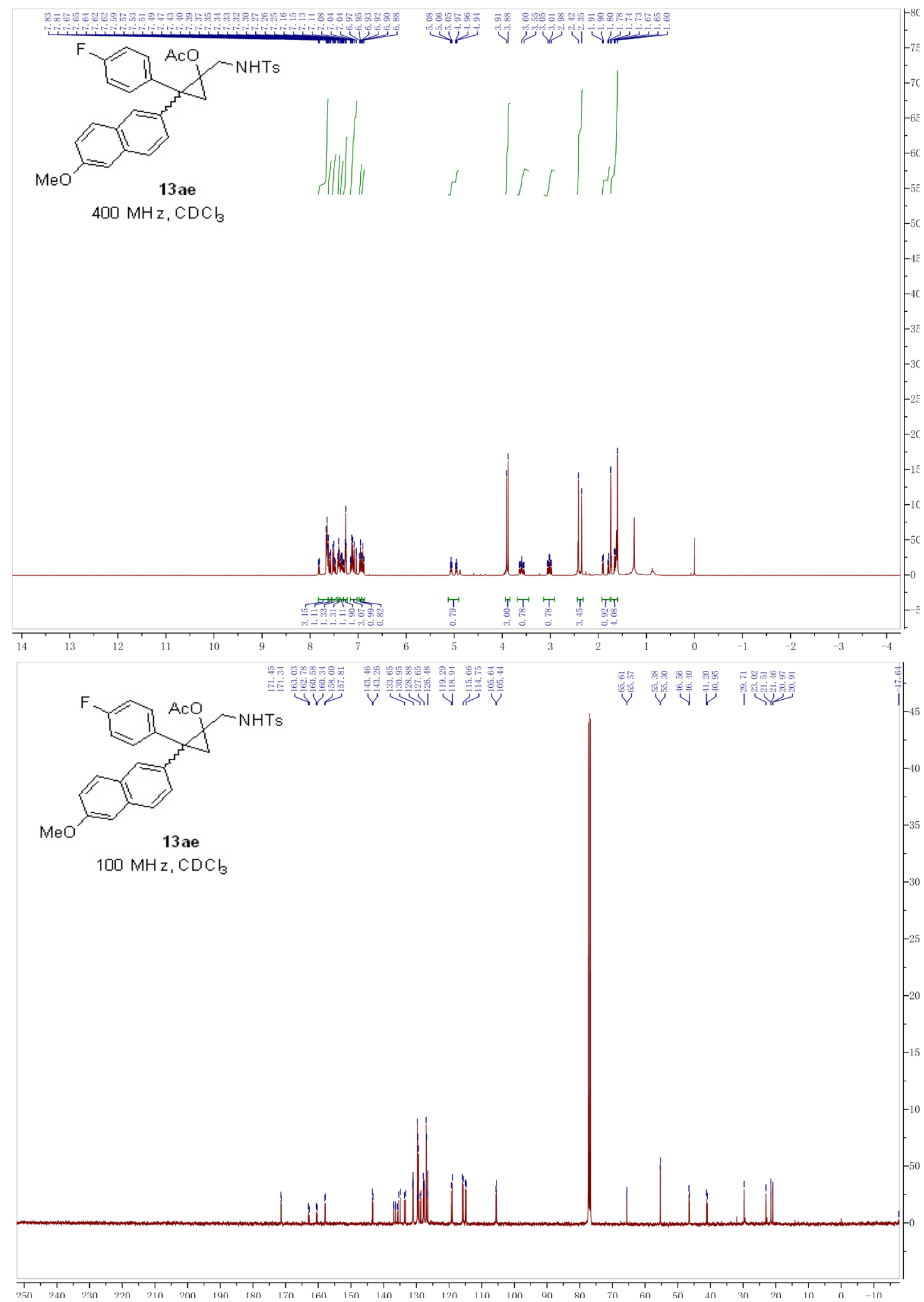



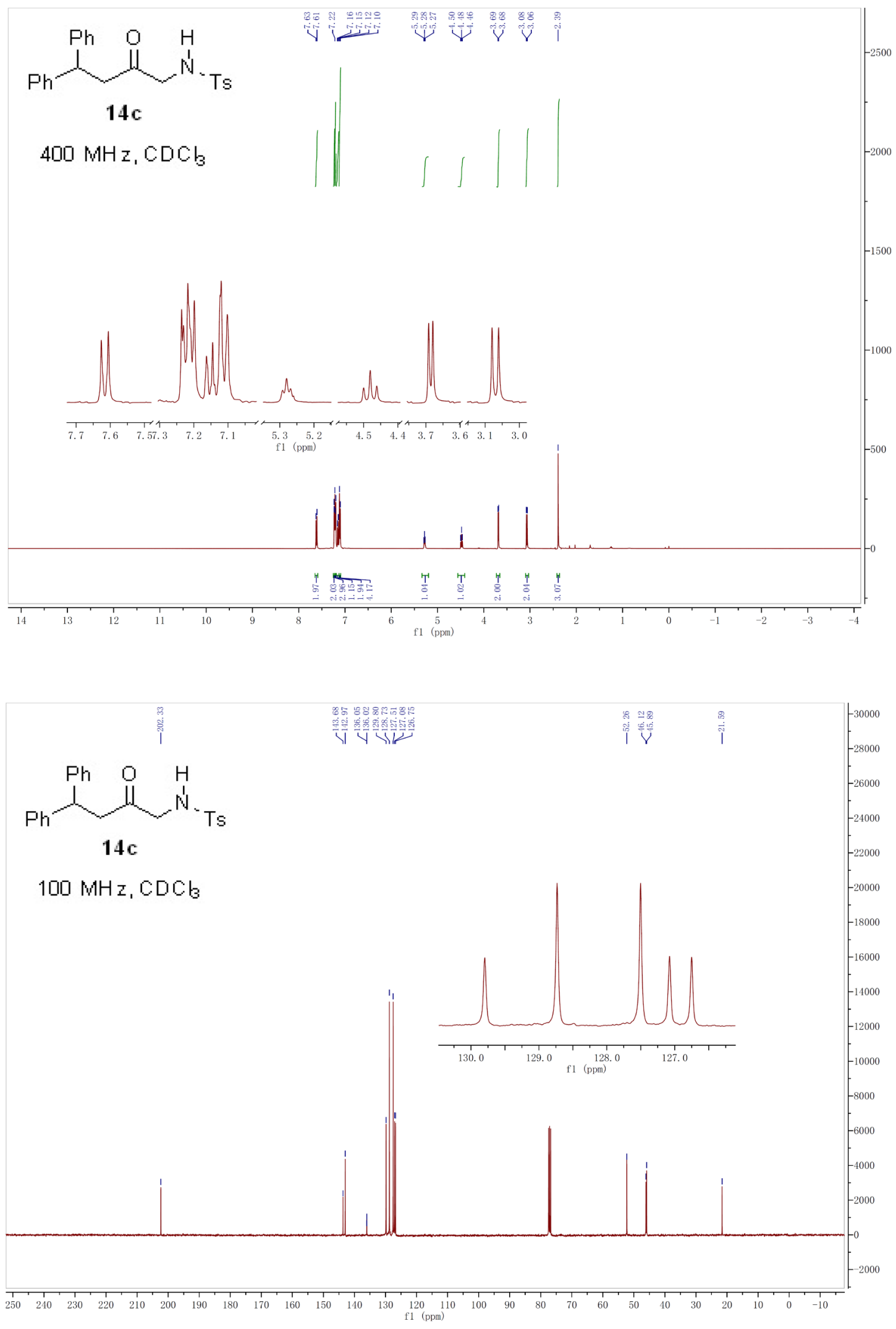

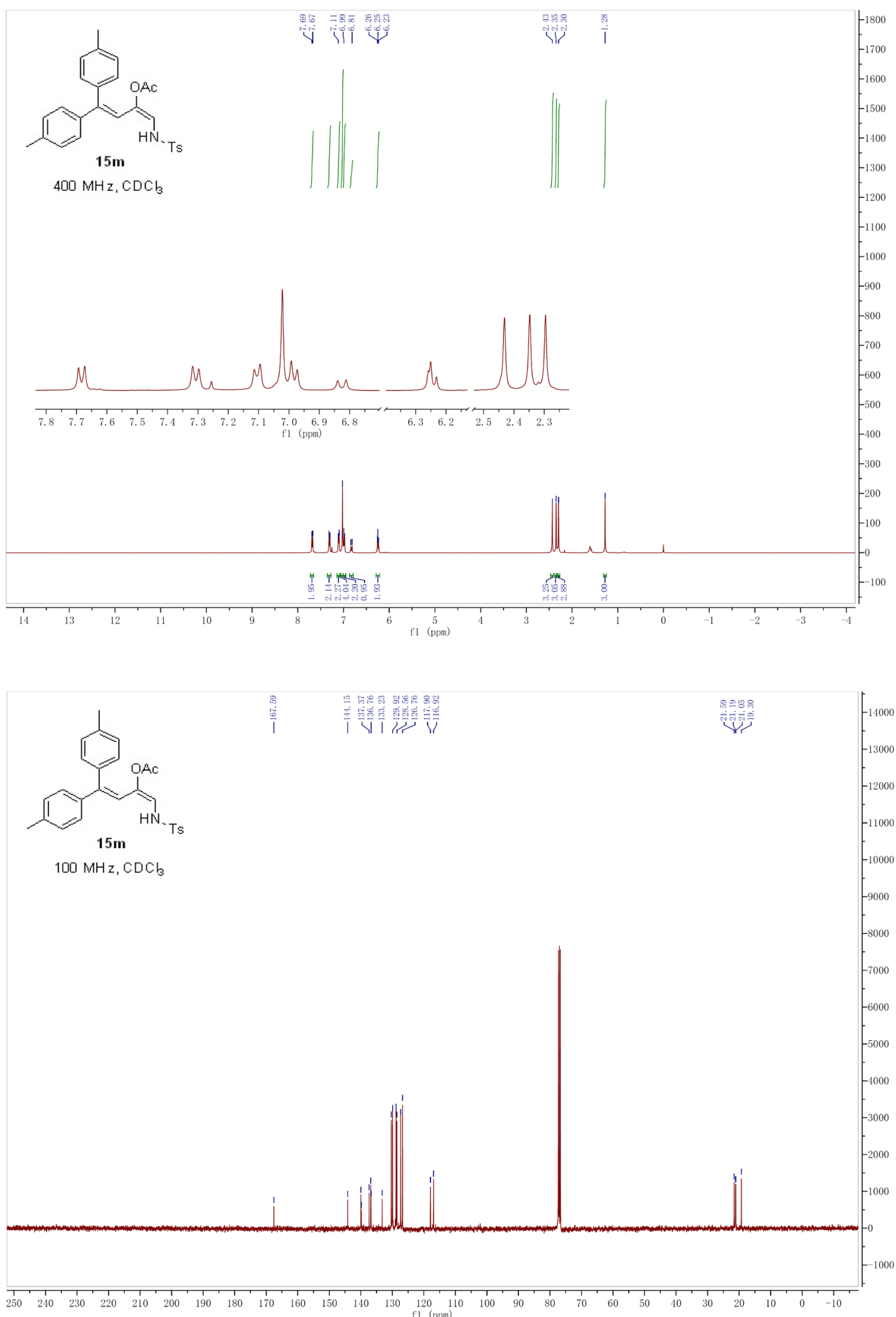


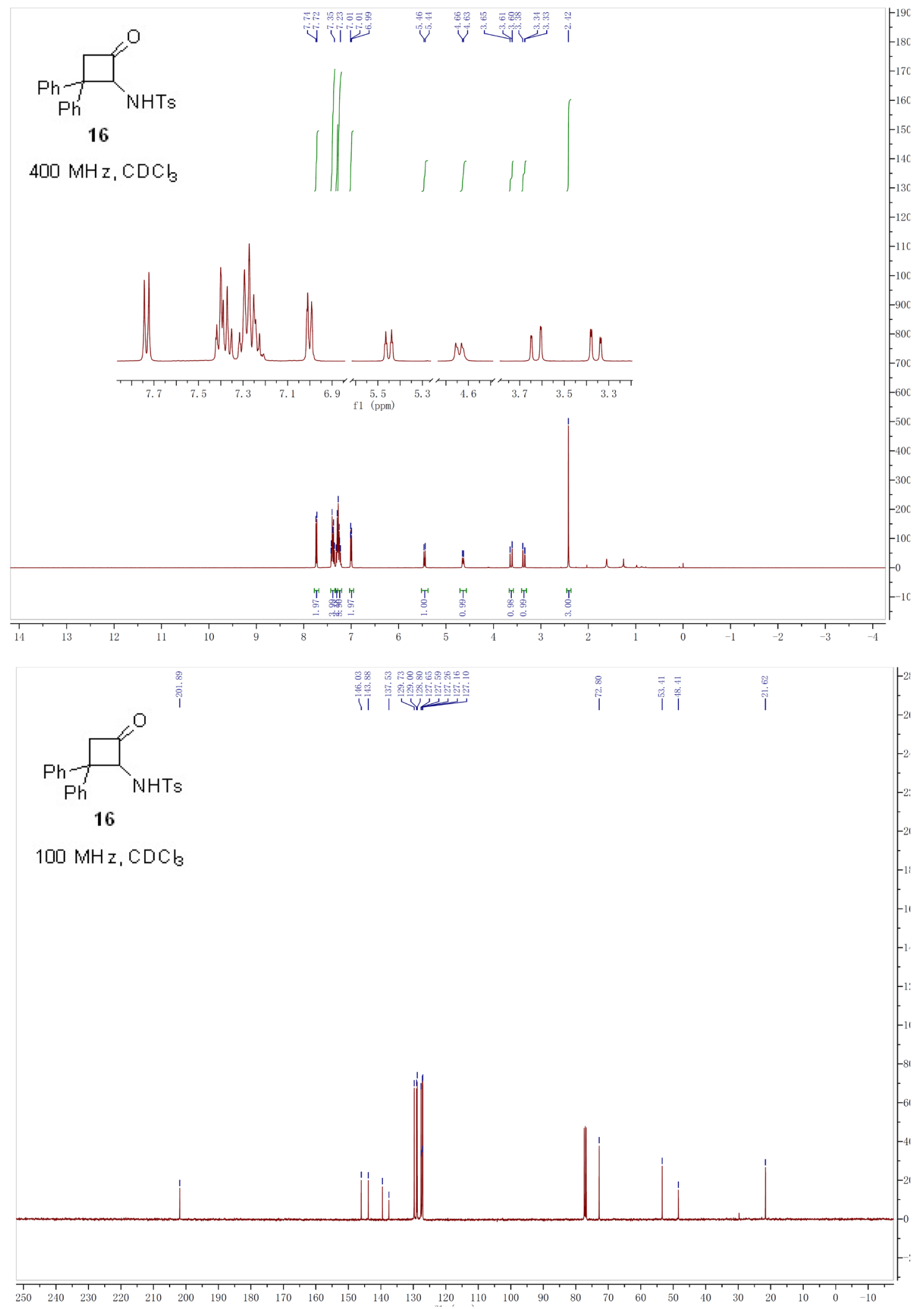

